УДК 563.13:551.781(477-13)

\title{
T.S. Ryabokon
}

\section{BIOSTRATIGRAPHY OF PALEOGENE THE SOUTHERN UKRAINE BY SMALL BENTHIC FORAMINIFERA: RETROSPECTIVE VIEW}

The article deals with history of small benthic foraminifera biostratigraphy of Paleogene deposits the southern Ukraine. The significance of O.K. Kaptarenko-Chernousova, A.M. Voloshina, M.V. Yartseva, Ye.Ya. Kraeva, A.P. Pechenkina, N.G. Savenko and I.D. Konenkova's works on study foraminifera is shown. Due to their investigarions the sequence and space-time relationships of Paleogene small benthic foraminifera assemblages have been determined in the southern Ukraine. Comparison foraminifera assemblages of Paleogene the southern Ukraine with intergerional benthic foraminifera zones of the Crimea-Caucasus Region is given. The article provides full references to previous literature on Paleogene foraminiferal biostratigraphy of the northern Peri-Black Sea Region and the southern slope of Ukrainian Shield. Up to the beginning the seventies years of the last century the researchers had distinguished and had described foraminifera assemblages characterizing Series and regional units of Paleogene the southern Ukraine. Taxonomic composition of benthic foraminifera assemblages was defined. Their spreading in Paleogene section of the northern Peri-Black Sea Region, the southern slope of Ukrainian Shield and adjacent part the Azov Crystalline Massif was studied. For some foraminifera assemblages the regional significance has been proved. Other assemblages are important for characterizing and dating suites, members, stratum and beds of the local stratigraphic schemes. Foraminifera associations of relatively deep-water depositional environments of the south of the northern Peri-Black Sea Region include species of zonal assemblages of interregional benthic foraminifers zones the Crimea-Caucasus Region. The most of distinguished benthic foraminifera assemblages are characteristic for shallow- and marginalmarine sediments of Paleogene basin in the northern Peri-Black Sea Region and its peripheral facies within depressions the southern slope of Ukrainian Shield. The space-time relations of benthic foraminifera assemblages are defined for Paleogene regional stages of the southern Ukraine section.

Key words: benthic foraminifera, Paleogene, biostratigraphy, southern Ukraine.

Introduction. Biostratigraphic units of foraminifera, namely zones and beds with fauna according to Stratigraphic Code of Ukraine [12, 92] and of the former Soviet Union [116], are among subdivisions grounded the Regional Stratigraphic Scheme of Paleogene deposits the southern Ukraine. Characteristic assemblages of zones and beds with foraminifera of the Scheme [64, 90, 91] include small benthic foraminifera (BF). Biostratigraphic units of small BF presented in the modern Regional Stratigraphic Scheme of Paleogene the southern Ukraine are compared to zonal associations of planktic and large foraminifera, calcareous nannofossils and dinoflagellate cysts.

Most of stratigraphically important small BF assemblages of the Paleogene the south Ukraine had been distinguished by O.K. Kaptarenko-Chernousova, M.V. Yartseva, A.M. Voloshina, Ye.Ya. Kraeva, A.P. Pechenkina, N.G. Savenko and I.D. Konenkova in the 50-60s years of $X X$ century. Due to the further investigations of mentioned researchers and others the temporal and spatial distribution of these assemblages in Paleogene sediments of the northern Peri-Black Sea Region and adjacent areas of the Ukrainian Shield has been studied. For some of them regional significance has been proved, others have remained as local biostratigraphic subdivisions important for dating and characterizing suites (formations), members, stratum and beds. At the same time the current state of development zonal foraminiferal biostratigraphy of Paleogene deposits the southern regions of former Soviet Union (the Crimea-Caucasus Region) (CCR here, and in later text) [9, 39] allows more precise determination the stratigraphic position of small BF assemblages in Paleogene section the southern Ukraine.

The article deals with history of small BF biostratigraphy of Paleogene deposits the southern Ukraine, i.e. the northern Peri-Black Sea Region (NPBSR here, and in later text) and adjacent parts of the Ukrainian Shield (US here, and in later text) and Azov Crystalline Massif (ACM here, (C) Т.С. Рябокнь, 2019 
and in later text). The main aim of the article is to show significance of foraminifera study by O.K.Kaptarenko-Chernousova, M.V. Yartseva, Ye.Ya. Kraeva, A.P. Pechenkina, A.M. Voloshina, N.G. Savenko, I.D. Konenkova for Paleogene biostratigraphy the southern Ukraine.

Notes on modern state of Paleogene stratigraphy of the southern Ukraine. The Ukraine sedimentary cover is divided into regional units. By the National Stratigraphic Code of Ukraine $[12,92]$ the main stratigraphic unit is a Regional Stage (Regiostage; syn.: Regional Horizon, Stratohorizon) regarding as reflection of stages of sedimentary basin' geological history, i. e. its peculiarities sedimentation, transgressive-regressive cycles, (sequence) evolution of fauna or/and flora and others.

The Stratigraphic Scheme of Paleogene the southern Ukraine includes the general, regional and local parts [64, 90, 91]. The first, general, part includes Series, Subseries and Stages of Paleogene International Stratigraphic Scale (ISS here, and in figures). The second part, Regional Scale, presents stratigraphic sequence of Regional Stages of Paleogene the southern Ukraine. The third, local, part of the Scheme reflects stratigraphic sequence and correlation of suites, members, stratum and beds of the structural-facial districts of the southern Ukraine.

Regional Stages of the Paleogene of southern Ukraine have rather interesting and long history of distinguishing, definition and ratification by Commission on Paleogene Stratigraphy of Interdepartmental Stratigraphic Committee of the former Soviet Union and by Regional Interdepartmental Stratigraphic Committee of Ukraine up to the end of XX century. Brief description of Paleogene Regiostages the southern Ukraine and special literature on that question are in the article [115]. All Paleogene Regiostages of the Southern Ukraine are identified as valid (real) stratigraphic units according to Stratigraphic Code of Ukraine [12, 92]. They have been accepted in following official stratigraphic schemes of Ukraine: "Regional Stratigraphic Schemes of Paleogene Deposits the South Ukraine Oil and Gas Area" [91], "Stratigraphic Scheme (Unified) of the Ukraine Paleogene Deposits" [64], "Stratigraphic Scheme of Paleogene Deposits of the Southern Regions of Ukraine" [90].

Succession of regional stages in official Regional Stratigraphic Scale (Regional SS here, and in figures) of the Paleogene of southern Ukraine (including the Crimea) is as follows: Paleocene - the Belokamenskian (Danian - lower part of Selandian) and Kachian (Selandian - Thanetian); Eocene - the Bakhchisaraian (lower Ypresian), Simferopolian (upper Ypresian - lower Lutetian), Novopavlovkian (Lutetian), Kumian (Bartonian), Almian (Priabonian); Oligocene - the Planorbellian (lower Rupelian), Molochnian (middle Rupelian) and Kerleutian (upper Rupelian Chattian). Paleogene regiostages of the southern Ukraine, except the Molochnian, are defined or characterized by regional or provincial biozones of planktic and benthic foraminifera (table).

Biostratigraphic Scheme of Paleogene the southern Ukraine includes three kinds of biostratigraphic units of foraminifera, namely lone (= provincial biozone), biozone (assemblagezone) and beds with foraminifera.

Most of suites, members, stratum and beds of Local Stratigraphic Schemes of Paleogene of the southern Ukraine [64, 67, 90, 91] are characterized by BF biozones, mainly assemblagezones, and beds with foraminifera. Biostratigraphic zone (biozone) is a rock association contained the zonal assemblage of fossils (foraminifera). But according to the Stratigraphic Code of Ukraine [12] in the cases of undivided on zones deposists or in one gelogical section an auxiliary biostratigraphic unit the beds with fauna (or flora) are distinguished.

Materials and methods, research area. All published works on small BF including data on their distribution in sections, description of associations, intra- and interregional correlation based on foraminifera study, and also on corresponding beds with small BF to other associations of fossils, especially planktic and large foraminifera, calcareous nannofossils, organic-walled microphytoplankton have been analyzed. Presented in the article biostratigraphic generalization of the half past of $X X$ century is based mainly on scientific elaborations of Ye.Ya. Kraeva [41-62 et al.], M.V. Yartseva [104-108 et al.], A.M. Voloshina [4, 10, 102, 103], A.P. Pechenkina [40, 59, 72, 73], I.D. Konenkova [21-37 et al.], N.G. Savenko [70, 82-84,101]. Also some works of O.K. Kaptarenko-Chernousova [16-19], E.K. Schutzkaya [89] and others [6, 63, 74-78] have been 
Small benthic foraminifera in characteristic assemblages of fossils

of the Paleogene regional stages of the southern Ukraine

\begin{tabular}{|c|c|c|c|c|c|}
\hline \multicolumn{3}{|c|}{ GSS } & \multicolumn{3}{|r|}{ Regional Stratigraphic Scheme of Paleogene the Southern Ukraine } \\
\hline \multirow[b]{2}{*}{$\frac{\Xi}{\frac{1}{\omega}}$} & \multirow[b]{2}{*}{$\cdot \frac{\mathscr{s}}{\bar{D}}$} & \multirow[b]{2}{*}{ 总 } & \multirow{2}{*}{ 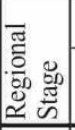 } & \multicolumn{2}{|r|}{ Biostratigraphic units: lones (provincial zones), regional zones $[64,91]$} \\
\hline & & & & $\begin{array}{l}\text { Lona, Zona } \\
\text { of foraminifera }\end{array}$ & Small benthic foraminifera in characteristic assemblages of fossils $[64,90,91]$ \\
\hline & \multirow{5}{*}{ 过 } & .ే & \multirow{2}{*}{ 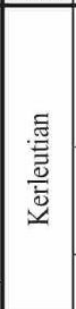 } & $\begin{array}{l}\text { Porosononion } \\
\text { dendridicus, } \\
\text { Elphidium } \\
\text { onerosum }\end{array}$ & $\begin{array}{l}\text { Porosononion dendridicus (Chal.), Cribrononion onerosum Bogd., Cibicidoides } \\
\text { ornatus (Bogd.), Nonion granosus Orb., Quinqueloculina aff. selenae (Karr.), } \\
\text { Spiroplectammina caucasica Djan., Bolivina aff. goudkoffi (Rank.) }\end{array}$ \\
\hline & & 胥 & & $\begin{array}{l}\text { Sphaeroidina } \\
\text { variabilis }\end{array}$ & $\begin{array}{l}\text { Sphaeroidina variabilis Reuss, Haplophragmoides kerleuticus Kosir (msc.), } \\
\text { Spiroplectammina terekensis Bogr., Uvigerinella californica Cushm., } \\
\text { Cibicidoides nefastus (J.Nik.) }\end{array}$ \\
\hline & & \multirow{3}{*}{ 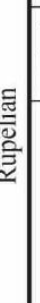 } & 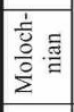 & & \\
\hline & & & 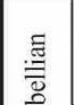 & $\begin{array}{c}\text { Spiroplectammina } \\
\text { oligocenica }\end{array}$ & $\begin{array}{l}\text { Spiroplectammina oligocenica (J.Nik.), Cyclammina contrictimargo Srew. et } \\
\text { Stew., Neogyroidina memoranda Subb., Caucasina schischkinskyae (Saml.), } \\
\text { Uvigerinella majcopica Kraeva }\end{array}$ \\
\hline & & & 产 & $\begin{array}{l}\text { Lenticulina } \\
\text { herrmani }\end{array}$ & $\begin{array}{l}\text { Lenticulina herrmani (Andr.), Heterolepa almaena (Saml.), Cibicidoides } \\
\text { extremus Schutz., Bolivina mississippiensis Cushm., Gaudryinopsis gracilis } \\
\text { Cushm. et Laim. }\end{array}$ \\
\hline \multirow{7}{*}{\multicolumn{2}{|c|}{ 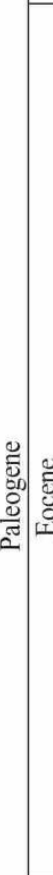 }} & 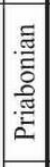 & 閙 & $\begin{array}{l}\text { Bolivina } \\
\text { antegressa } \\
\text { and large } \\
\text { globigerinids }\end{array}$ & $\begin{array}{l}\text { Bolivina antegressa Subb., Marsonella indentata (Cushm. et Jarv.), } \\
\text { Vulvulina spinosa Cushm., Marginulina behmi (Reuss), Marginulinopsis } \\
\text { infracompressus (Thalm.), Robulus kubinyii (Hantk.), Uvigerina jacksonensis } \\
\text { Cushm., Cibicidoides kasinaensis (Schutz.), C.jankulaensis (Schuts.), } \\
\text { Rectuvigerina lacera (Subb.) }\end{array}$ \\
\hline & & : & 䄈 & $\begin{array}{l}\text { Subbotina } \\
\text { turcmenica, } \\
\text { Subbotina } \\
\text { instabilis }\end{array}$ & $\begin{array}{l}\text { Baggina valvulineriaformis (N.Byk.), Brotzenella acuta taurica (Saml.), } \\
\text { Heterolepa pygmeuformis Kraeva, Caucasina eocaenica Chal. } \\
\text { (for the northern Peri-Black Sea Region) }\end{array}$ \\
\hline & & \multirow{5}{*}{ : } & \multirow{2}{*}{ 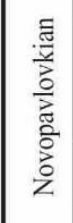 } & $\begin{array}{l}\text { Globigerinatheka } \\
\text { subconglobata, } \\
\text { Hantkenina } \\
\text { alabamensis }\end{array}$ & $\begin{array}{l}\text { Spiroplectammina carinatiformis Mor., Falsoplanulina ammophila (Guemb.), } \\
\text { Heterolepa eocaena (Guemb.), Uvigerina costellata Mor., Paragaudryina } \\
\text { dalmatina (Lieb.) }\end{array}$ \\
\hline & & & & $\begin{array}{c}\text { Acarinina } \\
\text { rotundimarginata }\end{array}$ & $\begin{array}{l}\text { Pseudogaudryina pseudonavarroana (Bal.), Clavulinoides golubjatnikovi } \\
\text { (Schutz.), Hydromylinella iljini (N.Byk.), Heterolepa eocaena (Gumb.) }\end{array}$ \\
\hline & & & \multirow{2}{*}{ 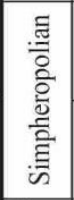 } & $\begin{array}{l}\text { Acarinina } \\
\text { bullbrooki }\end{array}$ & \multirow{2}{*}{$\begin{array}{l}\text { Vaginulinopsis eofragaria Bal., Falsoplanulina ammophyla (Gumb.), } \\
\text { Pseudogaudryina pseudonavarroana (Bal.) }\end{array}$} \\
\hline & & & & $\begin{array}{l}\text { Morozovella } \\
\text { aragonensis s.l. }\end{array}$ & \\
\hline & & & 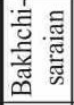 & $\begin{array}{l}\text { Morozovella } \\
\text { subbotinae s.1. }\end{array}$ & $\begin{array}{l}\text { Pseudogaudryina externa Bugr., Vaginulinopsis eofragaria } \text { Bal., } \\
\text { Cibicidoides beatus (Martin) } \\
\text { (for the northern Peri-Black Sea Region) }\end{array}$ \\
\hline \multirow{5}{*}{\multicolumn{2}{|c|}{ 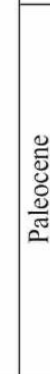 }} & \multirow{3}{*}{ 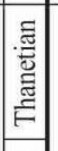 } & \multirow{3}{*}{.్ֶ } & $\begin{array}{l}\text { Acarinina } \\
\text { acarinata }\end{array}$ & \\
\hline & & & & $\begin{array}{c}\text { Acarinina } \\
\text { subsphaerica }\end{array}$ & Anomalina fera Schutz. \\
\hline & & & & Igorina djanensis & \\
\hline & & 苞 & \multirow{2}{*}{ 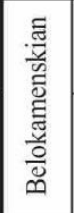 } & $\begin{array}{l}\text { Morozovella } \\
\text { angulata }\end{array}$ & $\begin{array}{l}\text { Gaudryina gigantica Subb., Anomalina danica Brotz., Falsoplanulina } \\
\text { ekblomi (Brotz.), Cibicidina bundensis (van Bell.) }\end{array}$ \\
\hline & & 䄏 & & $\begin{array}{l}\text { Praemurica } \\
\text { inconstans } \\
\text { Globoconusa } \\
\text { daubjergensis }\end{array}$ & $\begin{array}{l}\text { Arenobulimina dubia Wolosch., Cibicidoides burlingtonensis (Jenn.), } \\
\text { Anomalina danica Brotz., Stensioina caucasica (Subb.) }\end{array}$ \\
\hline
\end{tabular}


taken into account. Author's materials on foraminifera from outcrops and boreholes sections of central and eastern part of the NPBSR, the southern part of the US and the western ACM Region are also taken into account. The article is accompanied by a complit list of references on Paleogene foraminiferal biostratigraphy the studying region.

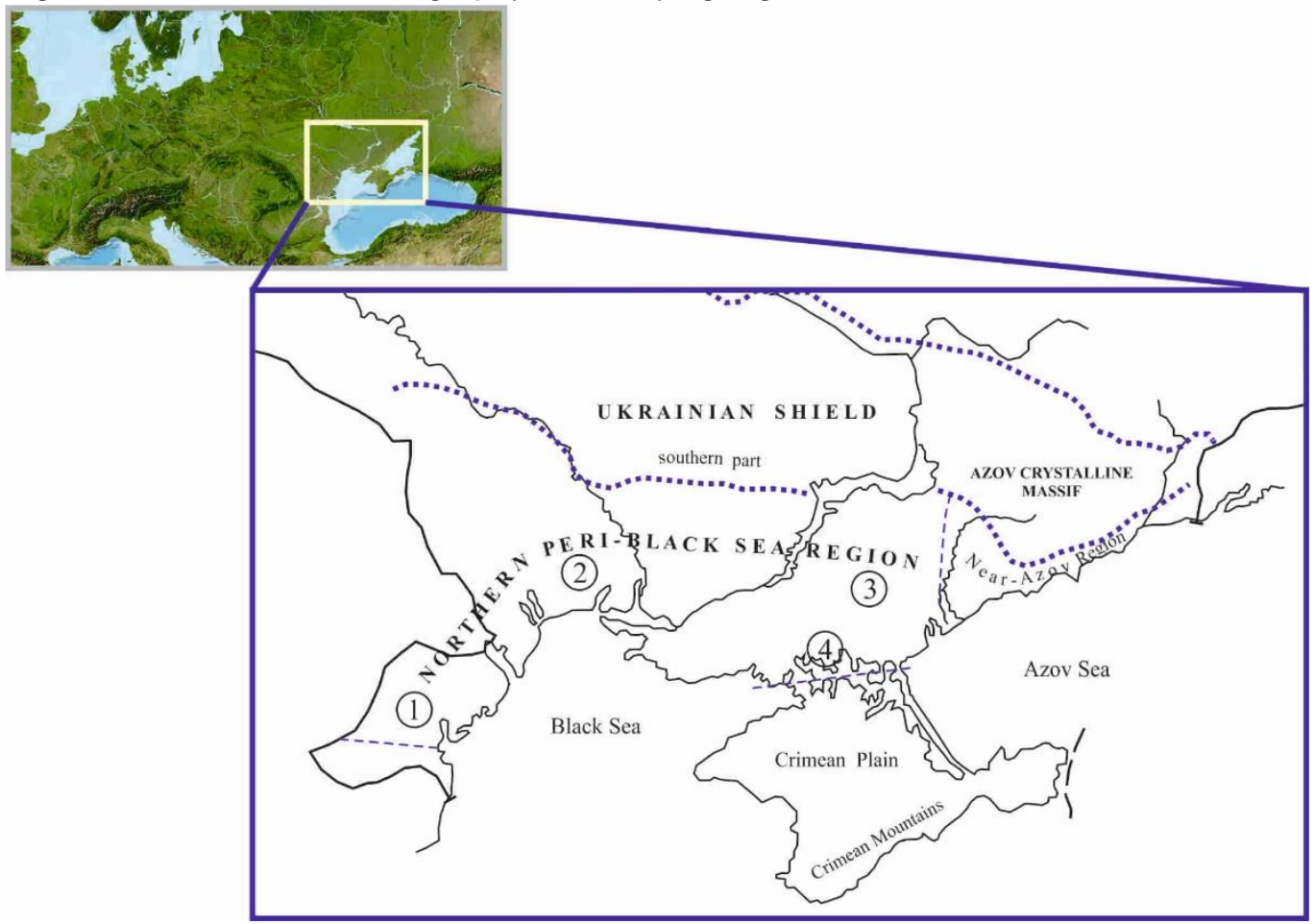

Fig.1. Research area of the southern Ukraine

The Peri-Black Sea Region: 1 - the south-western part; 2 - the western (central) part; 3 - the eastern part; 4 - the Near Sivach

Presented in the article author's bistratigraphic interpretation of BF assemblages of the southern Ukraine is based on modern foraminiferal zonation of the Paleogene of the south Russia, Crimean Peninsula, Central Asia and the Kazakhstan [9, 38, 39]. Yu.P. Nikitina's study of BF distribution in Paleogene of the south-east the Russian Platform and Skythian Plate [66] is also taken into account. The investigations are based on actualizes Regional Stratigraphic Scale of the southern Ukraine worked out by author in common with B.F. Zernetskiy and S.A. Lulyeva ${ }^{\dagger}$ [115].

In the describing part of article the term the beds with foraminifera is used in informal significance.

Because of the need to revise the systematic composition of Paleogene foraminifera the southern Ukraine, the table on small BF distribution is not given in the article. For the same reason, the names of foraminifera species are given in the wording of the authors of publications.

In the article BF associations are described from Paleogene deposits of the northern slope of Peri-Black Sea Depression more known in literature on stratigraphy as the NPBSR (Northern Prichernomorye), the southern slope of the US, the western, eastern and southern slopes of the ACM (Priazovie) (fig. 1). BF assemblages from Paleogene deposits of the Crimean Plain and foothills of the Crimean Mountains are not considered in the article.

Brief history of foraminifera studying of Paleogene the southern Ukraine. Due to investigations of O.K. Kaptarenko-Chernousova, M.V. Yartseva, Ye.Ya. Kraeva, A.M. Voloshina, 
A.P. Pechenkina, N.G. Savenko and I.D. Konenkova the taxonomic composition of small foraminifera of Paleogene deposits the NPBSR and adjacent area of the US had been identified by the end of the seventies of the last century. Researchers have determined foraminifera associations of Paleocene, Eocene and Oligocene Subseries and those of regional stages (regional horizons) and have distinguished characteristic species and biostratigraphic units by small foraminifera for different regions.

Study of small foraminifera for stratification of Paleogene sections in the NPBS and manganese-ore deposits of the US was started by O.K. Kaptarenko-Chernousova and M.V. Yartseva in the fortieth of the last century.

In her works "Stratigraphy of Paleogene deposits of the Peri-Black Sea Depression (by foraminifera fauna)" [17], "About Lower Oligocene horizon with arenaceous foraminifera of the Peri-Black Sea Depression" [19] O.K. Kaptarenko-Chernousova (foto 1) mentioned BF "horizon with arenaceous foraminifera" and "horizon with Spiroplectammina" for the region.

The most known and non-losing stratigraphic significance M.V. Yartseva's publications (foto 2) are "About Upper Eocene Miliolida of the Nikopol area and their habitat" [105], "To stratigraphy of Oligocene deposits of the south-eastern slope of Ukrainian Crystalline Shield (by foraminifera fauna)" [107], "Paleogene deposits of the southern slope of Ukrainian Crystalline Massif" [71]. She distinguished and determined stratigraphic position of some BF assemblages presenting in Local Stratigraphic Scheme of the south of US, namely "beds with miliolids, polymorphinids, Epistomaria rimosa", "beds with Nummulites variolarius, Cibicides carinatus, Rotalia armata", "beds with large lagenids, buliminids and Clavulina", "beds with Caucasina schischinskyae, Spiroplectammina oligocenica".

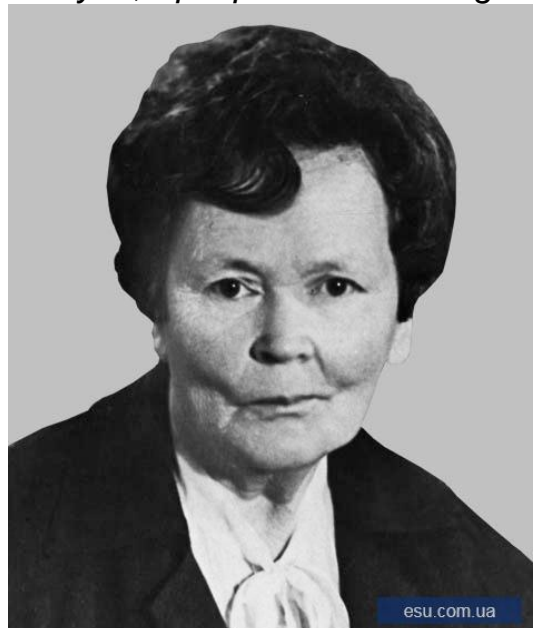

Foto 1. O.K. Kaptarenko-Chernousova

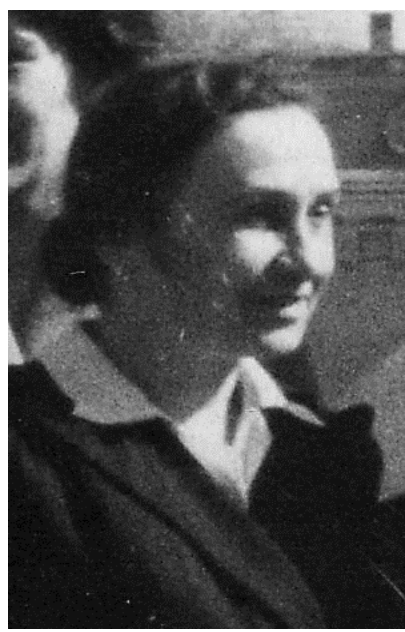

Foto 2. M.V. Yartseva

It should be mentioning A.M. Voloshina's works of the sixtieth of the last century on foraminifera assemblages of Danian and Paleocene sediments of the Crimean Plain and adjacent part of the NPBSR $[4,102,103]$. She also distinguished deposits of Paleocene, Lower, Middle and Upper Eocene, Oligocene based on foraminifera in the south of NPBSR [10].

A.P. Pechenkina was the first who described in detail small foraminifera distribution on Paleogene section of the Odessa area (the south-western part of NPBSR) [40]. She distinguished foraminifera assemblages for Paleogene Series and Subseries according to point on view on Paleogene stratigraphy of that time. She noted that Paleocene foraminifera association includes species Bolivinopsis spectabilis (Grzyb.), Anomalina danica (Brotz.), A. praeacuta Vass., Eponides lunatus Brotz., Siphonina prima Plum., Gyroidina globosa (Hag.), Angulogerina wilcoxensis (Cushm. et Pont.) be known from Paleocene deposits of the Dnieper-Donets Depression, Crimean Peninsula and Caucasus. Lower-Middle Eocene deposits are characterized by two foraminifera complexes. The first one with numerous nummulitids, orbitoides, Pulvinulinella granulosa Moroz. (msc)., Asterigerina norvaugi Brotz., she considered be 
analogous Lower Eocene "beds with Pulvinulina granulosa Moroz." of the West Crimea (today: Ypresian clays with Morozovella subbotinae (Moroz.)). The second association with Heterostomella dalmatina (Liebus), H. pseudonavarroana Balakhm., Clavulina golubjatkikovi Schutzk., Cl. aff. szaboi Hantk., Uvigerinella kiewensis Kapt. (msc.), Tritaxilina identata (Cushm. et Jarv.) A.P. Pechenkina regarded be analogous the lower part of "zone Globorotalia crassaeformis" of the North Caucasus and Crimean Peninsula.

From the Upper Eocene section of the Odessa area A.P. Pechenkina described the following succession of four foraminifera associations (from older to younger):

- association with dominating Globorotalia, presence of typical Clavulina szaboi Hantk., appearance of Hantkenina alabamensis Cushm., which she compared with upper part of "zone Globorotalia crassaeformis" of the Crimea and Northern Caucasus;

- association with numerous Globorotalia crassaeformis (Gall. et Wiss.), G-lia penracamerata Subb. and Globireginidae;

- association with small-size planktic foraminifera correlating with the same zone of planktic foraminifera of the Northern Caucasus and with "zone of small Bolivina and Bifarina millepuctata" of the Crimean Peninsula;

- association with rare Cristellaria cultrata (Montf.), Bolivina reticulata Hantk., B. pusilla Schw., Uvigerina asperula Cz., Uv. auberiana Orb., Uv. jacksonensis Cushm., Uv. cocoaensis Cushm., transition form from Bulimina truncana Guemb. to Bul. sculptilis Cushm., Anomalina praeacuta J. Nik. et Moroz. dampelae J. Nik. in litt., Cibicides pseudoungerianus Cushm., which she considered similar the Northern Caucasus "zone of large Globigerina".

In Oligocene part of the Odessa section, according to point of view on Paleogene stratigraphy of that period, A.P. Pechenkina identified the following foraminifera assemblages (from older to younger):

- association with numerous nummulitids and dominating buliminids (Bolivina, Uvigerina) which she correlated with "zone Bolivina" of the Northern Caucasus;

- association with rare Nummulites and numerous Anomalinidae (Anomalina affinis (Hantk.), An. alazanensis Nutt., An. grosserugosa (Guemb.)) and Lagenidae, frequent Haplophragmoides aff. deforme Andr., Heterostomella sp., Cristellaria cultrata (Montf.), Cr. cultrata (Montf.) arcuato-striata (Hantk.), rare Nonion umbilicatulum (Montf.), N. labradoricus (Daws.), N. aff, schaphum (Fich. et Moll.), Uvigerina pygmea Orb., Uv. tenuistriata Nutt. (non Reuss), Valvulineria iphigenia Sam., Eponides ex gr. umbonatus (Reuss), Pulvinulinella almaensis Sam., Cibicides pygmeus (Hantk.), C. ungerianus Cushm., C. ungerianus (Orb.), C. Iobatulus (Walk. et Jac.), Rhabdammina eocaenica Cushm. et Hanna, Saccammina sphaerica M.Sars., Proteonina difflugiformis (Brady);

- association with arenaceous foraminifera and rare calcareous forms;

- association with non-numerous calcareous BF.

It is necessary to note the A.P. Pechenkina's publications of foraminifera assemblages of transition Eocene-Oligocene and Lower Oligocene of the NPBSR in which she has described "zone of arenaceous foraminifera and Haplophragmoides deformabilis" and "zone Asterigerina lucida and Cibicides salensis" [72, 73].

The main contribution into working out Paleogene foraminifera biostratigraphy of the southern Ukraine belongs Ye.Ya. Kraeva (foto 3). In her work "Foraminifera of Upper Eocene and Oligocene deposits the northern side of the Peri-Black Sea Depression" [44] she proposed the first zonal division of Eocene-Oligocene sections for different parts of the region. In section of the Tokmak-Melitopol area (the eastern part of the NPBSR) she distinguished the following foraminifera associatons (from older to younger):

- Upper Eocene "lagenids-globorotaliids zone" with numerous Lenticulina romeri (Reuss), Marginulina fragaria (Guemb.) and rare Lenticulina laticostata (Tutkow.), L. pseudomamilligera (Plum.), L. arcuato-striata (Hantk.), different Dentalina and Nodosaria, numerous Globorotalia pentacamerata Subb. (5-chamber Acarinina). Among characteristic species are Hydromylina rutteni Puyt., Uvigerina proboscidea Schwag., Valvulineria texana Howe et Wall., V. palmarealensis (Nutt.), Asterigerina stelligera Kraeva; 
- Upper Eocene "lagenids-globigerinids zone" with less various and numerous but larger in size lagenids (Lenticulina romeri (Reuss), Robulus inornatus Orb., Marginulina fragaria (Guemb.)), Nodosariidae, disappearance Globorotalia, presence Globigerinidae (Globigerinella micra (Cole), Globigerina bulloides Orb.), appearance Bolivina antegressa Subb. costifera Kraeva, Planulina costata (Hantk.), Pl. aff. venezuelana Nutt., Anomalina alazanensis Nutt., An. acutiformis Moroz. (msc.);

- Upper Eocene "buliminids zone" with various Buliminidae; among characteristic species are Marginulina infracompressa Thalm., Turrilina alsatica Andr., Bulimina sculptilis Cushm., B. aksuatica Moroz., Bolivina nobilis Hantk., Uvigerina jacksonensis Cushm., Uv. jacksonensis Cushm var. delicatula Kraeva, Uv. costellata Moroz.;

- Lower Oligocene "zone with arenaceous foraminifera" with various primitive agglutinated forms Rhabdammina cylindrica Glaessn., Proteonina fusiformis Will., Reophax scalaria Grzyb., Haplophragmoides kiewensis Kapt., Cyclammina cancellata Brady, Spiroplectammina carinata (Orb.), etc.

- Lower Oligocene "zone Spiroplectammina carinata" with numerous specimens of indexspecies and Caucasina schischkinskii (Sam.), Bolivina mississippiensis Cushm., less numerous Uvigerinella majkopica Kraeva, Cibicides oligocenicus (Sam.), C. pseudoungerianus Cushm., etc.

For the section of the Odessa-Kherson area (the central part of NPBSR) Ye.Ya. Kraeva introduced the following succession of foraminifera assemblages (from older to younger):

- Upper Eocene "zones with Hantkenina alabamensis" ("globorotaliids zone") with dominating planktic foraminifera; among characteristic benthic species are Nodosaria bacillum Defr., N. bulbosa Halk., Robulus kultratus Montf., R. arcuato-striata Hantk., Planularia infans Kraeva, Hydromylina ? rutteni Puyt., Anomalina pseudoacuta Moroz., An. acuta Plumm. discoidea Balakhm., An. affinis (Hantk.), Cibicides ungerianus (Orb.), Asterigerina stelligera Kraeva, Valvulineria palmarealensis (Nutt.), Siphonina kaptarenkae Kraeva, Kolesnikovella elongata (Halk.), Angulogerina proprius Kraeva,;

- Upper Eocene "zone with Globigerina apertura" ("globigerinids zone") with dominating Globigerina, Globigerinella; among characteristic BF are Planulina aff. venezuelana Kraeva, Siphonina praereticulata Kraeva, Valvulineria texana Howe et Wall., Bolivina antegressa Subb. costifera Kraeva and also Lenticulina limbosa Reuss, Nodosaria exilis (Neugeb.), Bolivina pusilla Schwag., B. arta Mact., B. aff. microlancetiformis Subb., Uvigerina jacksonensis Cushm., Uv. costellata Moroz., Uv. densecostata Kapt. (msc.), Baggina iphigenia (Sam.);

- Upper Eocene "zone with Marginulina infracompressa" or "middle zone" characterizing by impoverished foraminifera association with Marginulina infracompressa Thalm., Anomalina grosserugosa (Guemb.), Eponides jacksonensis Nutt., E. perlata Andr., Gyroidina soldanii Orb., Pullenia quinqueloba Reuss, Asterigerina bracteata Cushm., Uvigerina densecostata Kapt. (msc.), Turrilina alsatica Andr., Bolivina antegressa Subb., Cassidulina globosa Hantk.;

- Upper Eocene "zone with Asterigerina and Nonion" distinguishing by very impoverished complex of small BF with numerous Eponides stellatus Kraeva, Asterigerina ambiqua Kraeva, Nonion umbilicatulus (Montf.), Cibicides aff. oligocenicus Sam., C. aff. pseudoungerianus Cushm., Turrilina alsatica Andr.;

- Lower Oligocene "complex with Spiroplectammina carinata" (see above);

- Middle Oligocene "zone with Sphaeroidina variabilis" with numerous Spiroplectammina carinata Orb. follis Kraeva, Cibicides pseudoungerianus Cushm., C. oligocenicus Sam., Nonion umbilicatulus (Montf.), Uvigerinella majkopica Kraeva, Sphaeroidina variabilis Reuss.

In the Razdelnaya area section (the south-western part of the NPBSR) Ye.Ya. Kraeva distinguished the following succession of foraminifera assemblages (from older to younger):

- Upper Eocene "zone with Hantkenina alabamensis and Globigerina apertura" or "globorotaliids-globigerinids zone" marking by appearance Planulina costata (Hantk.), Bulimina sculptilis Cushm., Uvigerina hispida Schwag.; among characteristic BF are Planularia infans Kraeva, Hydromylina rutteni Puyt., Planulina aff. venezuelana Nutt., Siphonina kaptarenkae Kraeva, Uvigerina jacksonensis Cushm., Uv. hispida Schwag., Bolivina antegressa Subb., Angulogerina proprius Kraeva and others; 
- Upper Eocene "zone with Globigerinoides conglobatus" characterizing by Marginulina infracompressa Thalm., numerous index-species, Bulimina sculptilis Cushm., Uvigerina densecostata Kapt. (msc.), Uv. costellata Moroz., etc.;

- Upper Eocene "zone with Globigerina bulloides and arenaceous foraminifera" distinguishing by numerous agglutinated foraminifera Reophax ex gr. nodulosus Brady, R. plana Halk., R. scalaria Grzyb., Proteonina fusiformis Will., Haplophragmoides eggeri Cushm., Clavulina szaboi Hantk., Heterostomella dalmatina Liebus, impoverished association with calcareous forms Frondicularia budensis (Hantk.), Robulus carinatus Kraeva, Uvigerina densecostata Kapt. (msc.), Cassidulina globosa Hantk., Bifarina millepunctata Tutkow., Lingulina $\mathrm{sp}$.

Ye.Ya. Kraeva also distinguished the Paleocene "anomalinids complex" [58], the Middle Eocene "beds with Hopkinsina bykovae ukrainica" [97], the Upper Oligocene "zone Sphaeroidina" and "nonionids complex" [41,61] in the NPBSR.

I.D. Konenkova (foto 4) in her work "Foraminifera biostratigraphy of Danian and Paleocene deposits of the Northern Peri-Black Sea Region" [26] has proved by planktic and benthic foraminifera the presence of the Lower and Upper Paleocene deposits in the region. She has determined the following succession of shallow-water BF associations: "complex with Cibicidoides commatus", "complex with Anomalina burlingtonensis" and "complex with Cibicides bundensis and Nonion multisuturatum" in Lower Paleocene deposits and "complex with anomalinids" and "complex with Bolivinopsis spectabilis" in Upper Paleocene. Also she described Lower Eocene foraminifera association in the south of NPBSR [27, 33]. Doubtless interests has her articles devoted to description foraminifera associations of the Priabonian of the southern part of US [36] and the NPBSR [22], transitional Eocene-Oligocene interval of the eastern part of the NPBSR [30] and the eastern part of Near-Azov Region [31].

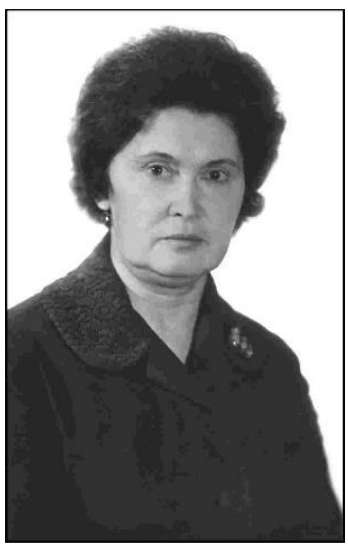

Foto 3. Ye.Ya. Kraeva

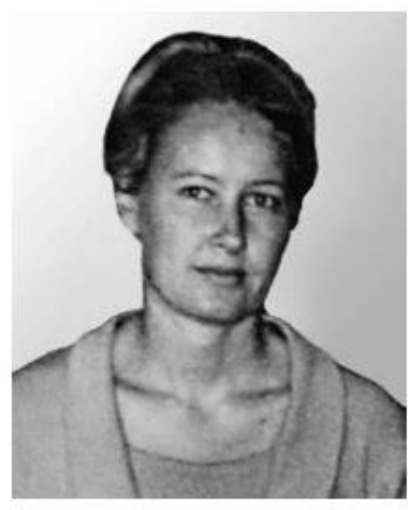

Foto 4. I.D. Konenkova

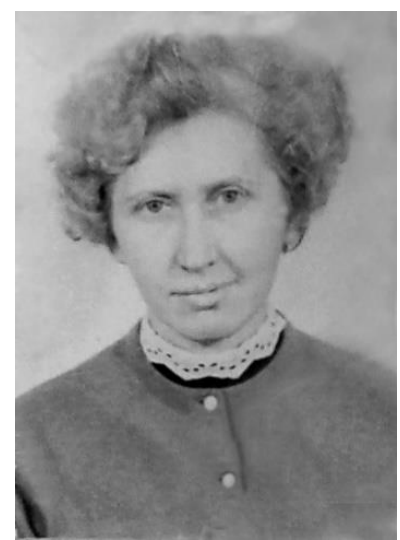

Foto 5. N.G. Savenko

N.G. Savenko (foto 5) in her dissertation "Biostratigraphy of Upper Eocene deposits the PeriBlack Sea Depression by small foraminifera" [83] and other works [11, 100, 101] has proved presence of foraminifera assemblages of the Kuberla, Keresta, Kuma and Alma Stratohorizons of the CCR in the NPBSR. She also described in detail foraminifera associations of those horizons for different parts of the NPBSR. N.G. Savenko grounded presence of three biostratigraphic zones in Priabonian deposits of the NPBSR connecting with different facies, namely "zone Nonion, Asterigerina and Nummulites" characterizing shallow-water sediments in central part of the region, "zone Asterigerina lucida and Cibicides salensis" of more deep-water sediments of the north-western part of the region and "zone Globigerinoides conglobatus and Bolivina antegressa" of the most deep-water sediments of the north-eastern and southern parts of the NPBSR.

Present state of benthic foraminifera biostratigraphy of Paleogene deposits of the northern Peri-Black Sea Region, adjacent areas of the Ukrainian Shield and Azov Crystalline Massif. This part of article deals with retrospective view on distinguishing 
associations of small BF in Paleogene deposits of the NPBSR and adjacent areas of the US and ACM, author's opinion on their stratigraphic position and correlation with interregional BF zones of the CCR [9, 38, 39].

Paleocene. Up to beginning the sixties years of the last century deposits of Paleocene age had been proved by foraminifera in narrow coastal zone along the northern Black Sea, Sivash Gulf and Azov Sea [10]. After A.M. Voloshina the Paleocene BF assemblage of the region includes Ataxophragmium variabile (Orb.) ${ }^{*}$, Spiroplectammina variata Vass. ${ }^{*}$, Textularia ex gr. baudoniana (Orb.), Gaudryina retusa Cushm. ., Marsonella aff. oxycona (Reuss)*, Dorothia buletta Carsey, Arenobulimina mohreni Brotz.*, Ar. dubia Wolosh.*, Ataxophragmium depressaeformis Ploth., At. frankei (Brotz.) ${ }^{*}$, Eponides saginaris N.Byk., Anomalina danica (Brotz.)* ${ }^{*}$, An. ekblomi (Brotz.)*, An. aff. praeacuta Vass. ${ }^{*}$, Valvulineria allomorphinoides Reuss, Gyroidina umbilicata (Orb.), Cibicides hemicompressus Moroz. ${ }^{*}$, C. incognitus Vass. ${ }^{*}$, C. lectus Vass. ${ }^{*}$, C. commatus Moroz. ${ }^{*}$

Author's notes. According to modern biostratigraphic ideas $[9,39]$ this assemblage corresponds to Danian interregional zone Anomalina danica s. I. of the CCR (fig. 2). This conclusion is grounded on presence characterizing species of the zone marked by $\left({ }^{*}\right)$ in the list.

Due to further foraminifera study of A.M. Voloshina, I.D. Konenkova, Ye.Ya. Kraeva, E.K. Schutzkaya the Paleocene section of the NPBSR was subdivided into lower (now = Belokamenskian Regiostage) and upper (now = Kachian Regiostage) Subseries.

Belokamenskian Regional Stage. A.M. Voloshina [4, 102] has described shallow-water "danian-paleocene" BF assemblage in borehole of the south-western part of Near-Azov Region. She indicated Arenobulimina mohreni Brotz., Ar. cuskleyae Jenn.*, Triloculina aff. inflata Orb., Quinqueloculina aff. inflata Orb., Guttulina ipatovcevi Vass., G. aff. austriaca Orb., G. lidiae Vass., Globulina amygdaloides Reuss, Gl. gibba Orb., Gl. rotundata (Born.), Anomalina danica (Brotz.)*, Cibicides simplex Brotz. ${ }^{*}$, C. reinholdi ten Dam, C. ekblomi Brotz. ${ }^{*}$, C. favorabilis Vass., Gyroidina octocamerata Cushm. et Hanna, Globorotalites lobata Brotz.*, Glob. aff. toulmini (Brotz.)*, Coleites crispus Vass., Elphidiella prima (ten Dam)* ${ }^{*}$ Nonion aff. graniferum (Terq.), Buliminella parvula Brotz. *, Bolivina aff. ödumi Brotz., Allomorphina halli Jenn.* et others.

Author's notes. This assemblag also corresponds to Danian interregional zone Anomalina danica s. I. of the CCR [9] (characterizing species are marked by $\left(^{*}\right)$ in the list).

Later I.D. Konenkova [26, 27] distinguished three BF assemblages in Lower Paleocene section of the NPBSR: "complex with Cibicides commatus", "complex with Anomalina burlingtonensis" and "complex with Cibicides bundensis and Nonion multisuturatum". She also described BF association of shallow-water peripheral facies of the Paleocene sea in Belokamenskian time.

Beds with Cibicidoides commatus were distinguished by I.D. Konenkova in boreholes 52 (Novokievka) and 72 (Novaya Mayachka) drilled in the Kherson area, the south of eastern part of the NPBSR. The BF association includes Ataxophragmium frankei Brotz., Arenobulimina presli Reuss, Ar. dubia Wolosch., Anomalina danica Brotz., An. burlingtonensis (Jenn.), An. ekblomi (Brotz.), An. umbilicata Mjatl., Cibicides invisus Vass., C. commatus Moroz., C. spiropunctatus Gall., Coleites reticulosus (Plumm.), Gyroidina umbilicata Orb., Eponides frankei Brotz., Globorotalites perforatus Vass., Pulsiphonina elegans Brotz. These layers coresponds to Danian planktic foraminifera zone Globoconusa daubjergensis [26, 27] and calcareous nannofossils zone NP $3[5,6]$, characterizing the Lower Belokamenskian Regional Substage of the southern Ukraine.

I.D. Konenkova $[26,28]$ has noted that BF assemblage of beds with Cibicidoides burlingtonensis in comparison with the same of beds with Cibicidoides commatus is some shallower and differs on appearance Anomalina midwayensis (Plumm.), Cibicides sahlstromi Brotz., C. neumanae Plumm., Gyroidina octocamerata (Cushm. et Hanna), Mississippina binkhorsti (Reuss), Reussella paleocenica (Brotz.), Rosalina selandiana Poz. et Szc., Pararotalia globigeriniformis (van Bell.). Researcher conditionally correlated these beds to planktic foraminifera Praemurica inconstans zone. Taking into account data on planktic foraminifera [4, 26, 102], beds with Cibicidoides burlingtonensis should be coresponded Danian lone Globoconusa daunbjergensis - Praemurica inconstans. 
In the southern part of Molochna river basin (the south-western part of the Near-Azov Region) I.D. Konenkova [25, 34, 35, 37] described the most shallow-water BF association of the beds with Cibicidoides burlingtonensis, which is distinguished by predomination of Anomalina danica Brotz., An. ekblomi (Brotz.), Cibicides burlingtonensis Jenn., C. neumanae Plumm., C. sahlstromi (Brotz.), numerous Nonion ex gr. graniferum (Terq.), Protelphidium ex gr. sublaeve (ten Dam) and less numerous polymorphinids and miliolids.

Author's notes. BF assemblges of beds with Cibicidoides commatus and beds with Cibicidoides burlingtonensis contain characterizing species of the Lower Belokamenskian Regional Substage of the southern Ukraine, namely Arenobulimina dubia Wolosh., Anomalina danica Brotz., Cibicidoides burlingtonensis (Jenn.), Pararotalia globigeriniformis (van Bell.) (see table). Also taxonomic composition of BF of the beds is close to that of Danian interregional zone Anomalina danica s. I. of the CCR [9] and zone Cibicidoides lectus characterizing the Pselian Regional Stage of the Dnieper-Donets Depression [80]. This is proved by presence Arenobulimina prestli Reuss., Ataxophragmium frankei Brotz., Anomalina danica Brotz., Gavelinella umbilicata Brotz., Cibicidoides commatus (Moroz.), Intricatus spiropunctatus (Gall. et Morr.), Gyroidinoides octocameratus (Cushm. et Hanna), Pulsiphonina elegans Brotz., Falsoplanulina ekblomi (Brotz.), Pararotalia globigeriniformis (van Bell.), Coleites reticulosus (Plumm.), Rosalina selandiana Poz. et Szc., Reusella paleocenica (Brotz.), Mississippina binkhorsti (van Bell.) and others in BF assemblages of the beds. On my opinion the described BF associations of beds with Cibicidoides commatus and beds with Cibicidoides burlingtonensis should be defined as assemblage-zone Anomalina danica and Cibicidoides commatus characterizing lower part of the Belokamenskian Regiostage in the NPBSR (see fig. 2). Authorship of this zone is preservated after I.D. Konenkova.

BF association of beds with Cibicidina bundensis and Nonion multisuturatum, distinguished by I.D. Konenkova [23, 25, 26, 35, 37] in the south of the eastern and western parts of the NPBSR, reflects shallow-marine depositional environments of peripheral parts of Paleocene sea in late Belokamenskian time. Differing by numerous anomalinids, polymorphinids, rotaliids and miliolids, the complex includes Anomalina danica (Brotz.) ${ }^{*}$, An. burlingtonensis (Brotz.), An. ekblomi (Brotz.) ${ }^{*}$, An. simplex (Brotz.), Cibicides sahlstromi Brotz., C. bundensis van Bell.*, C. succeedens Brotz., Nonion graniferum (Terg.), Nonion multisuturatum van Bell., Eponides toulmini Brotz., Globorotalites lobata Brotz., Rosalina koeneni Brotz., R. selandiana Poz. et Szc., Rotalia lithothamnica Unlig. katchanensis Schutzk., Pararotalia globigeriniformis (van Bell.), P. macheili Loebl. et Tapp., P. scabrosa Konen., Proteelphidium sublaeve (ten Dam.), Elphidiella prima (ten Dam.), Lamarckina rugulosa (Plumm.), Reussella paleocenica (Brotz.) and others. This assemblage contains characterizing species of the Upper Belokamenskian Regional Substage of the southern Ukraine (marked by $\left(^{*}\right)$ in the list). The beds also contain calcareous nannoplankton of zone NP $5[5,6]$, characterizing the same stratigraphic level.

Author's notes. Taking into account stratigraphic position of beds with Cibicidina bundensis and Nonion multisuturatum in the Lower Paleocene section of the south of NPBSR and data on calcareous nannofossils, these beds should be considered as the most shallow-water layers of the Upper Belokamenskian Regional Substage (see fig. 2) and probable stratigraphic analogue of Selandian interregional zone Pyramidina crassa of in the CCR [9].

Belokamenskian Regional Stage. A.M. Voloshina [4, 102] has described shallow-water "danian-paleocene" BF assemblage in borehole of the south-western part of Near-Azov Region. She indicated Arenobulimina mohreni Brotz., Ar. cuskleyae Jenn. ${ }^{*}$ Triloculina aff. inflata Orb., Quinqueloculina aff. inflata Orb., Guttulina ipatovcevi Vass., G. aff. austriaca Orb., G. lidiae Vass., Globulina amygdaloides Reuss, Gl. gibba Orb., Gl. rotundata (Born.), Anomalina danica (Brotz.)*, Cibicides simplex Brotz. ${ }^{*}$, C. reinholdi ten Dam, C. ekblomi Brotz. ${ }^{*}$, C. favorabilis Vass., Gyroidina octocamerata Cushm. et Hanna, Globorotalites lobata Brotz. ${ }^{*}$, Glob. aff. toulmini (Brotz.)*, Coleites crispus Vass., Elphidiella prima (ten Dam)*, Nonion aff. graniferum (Terq.), Buliminella parvula Brotz. ${ }^{*}$, Bolivina aff. ödumi Brotz., Allomorphina halli Jenn. ${ }^{*}$ et others.

Author's notes. This assemblag also corresponds to Danian interregional zone Anomalina danica s. I. of the CCR [9] (characterizing species are marked by $\left(^{*}\right)$ in the list). 


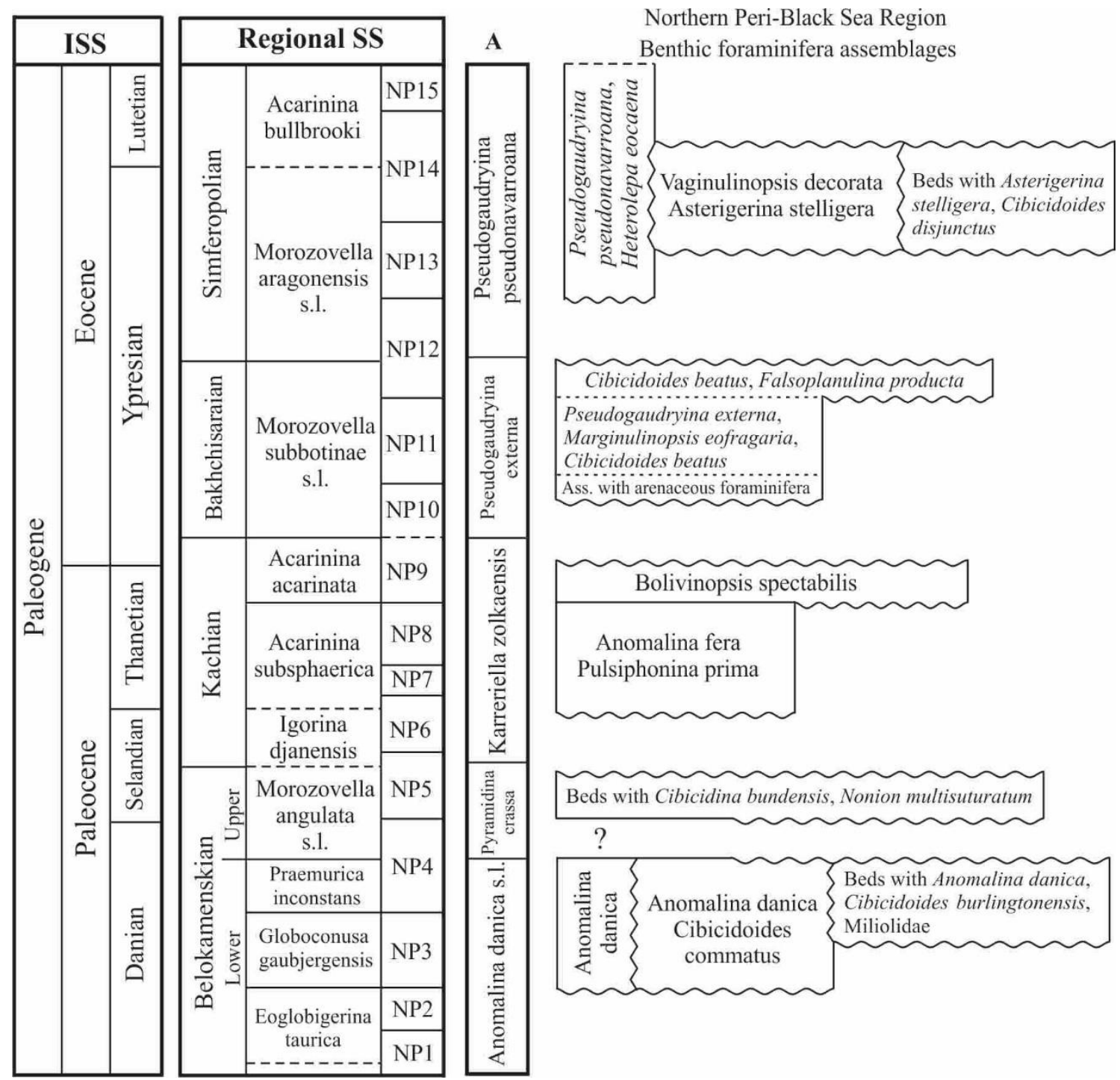

Fig. 2. Sequence of small benthic foraminifera assemblages in Paleocene - Lower Eocene the southern Ukraine

A - interregional benthic foraminifera zones of the Crimea-Caucasus Region [9, 39]

Later I.D. Konenkova [26, 27] distinguished three BF assemblages in Lower Paleocene section of the NPBSR: "complex with Cibicides commatus", "complex with Anomalina burlingtonensis" and "complex with Cibicides bundensis and Nonion multisuturatum". She also described BF association of shallow-water peripheral facies of the Paleocene sea in Belokamenskian time.

Beds with Cibicidoides commatus were distinguished by I.D. Konenkova in boreholes 52 (Novokievka) and 72 (Novaya Mayachka) drilled in the Kherson area, the south of eastern part of the NPBSR. The BF association includes Ataxophragmium frankei Brotz., Arenobulimina presli Reuss, Ar. dubia Wolosch., Anomalina danica Brotz., An. burlingtonensis (Jenn.), An. ekblomi (Brotz.), An. umbilicata Mjatl., Cibicides invisus Vass., C. commatus Moroz., C. spiropunctatus Gall., Coleites reticulosus (Plumm.), Gyroidina umbilicata Orb., Eponides frankei Brotz., Globorotalites perforatus Vass., Pulsiphonina elegans Brotz. These layers coresponds to Danian planktic foraminifera zone Globoconusa daubjergensis [26, 27] and calcareous nannofossils zone 
NP $3[5,6]$, characterizing the Lower Belokamenskian Regional Substage of the southern Ukraine.

I.D. Konenkova $[26,28]$ has noted that BF assemblage of beds with Cibicidoides burlingtonensis in comparison with the same of beds with Cibicidoides commatus is some shallower and differs on appearance Anomalina midwayensis (Plumm.), Cibicides sahlstromi Brotz., C. neumanae Plumm., Gyroidina octocamerata (Cushm. et Hanna), Mississippina binkhorsti (Reuss), Reussella paleocenica (Brotz.), Rosalina selandiana Poz. et Szc., Pararotalia globigeriniformis (van Bell.). Researcher conditionally correlated these beds to planktic foraminifera Praemurica inconstans zone. Taking into account data on planktic foraminifera [4, 26, 102], beds with Cibicidoides burlingtonensis should be coresponded Danian lone Globoconusa daunbjergensis - Praemurica inconstans.

In the southern part of Molochna river basin (the south-western part of the Near-Azov Region) I.D. Konenkova [25, 34, 35, 37] described the most shallow-water BF association of the beds with Cibicidoides burlingtonensis, which is distinguished by predomination of Anomalina danica Brotz., An. ekblomi (Brotz.), Cibicides burlingtonensis Jenn., C. neumanae Plumm., C. sahlstromi (Brotz.), numerous Nonion ex gr. graniferum (Terq.), Protelphidium ex gr. sublaeve (ten Dam) and less numerous polymorphinids and miliolids.

Author's notes. BF assemblges of beds with Cibicidoides commatus and beds with Cibicidoides burlingtonensis contain characterizing species of the Lower Belokamenskian Regional Substage of the southern Ukraine, namely Arenobulimina dubia Wolosh., Anomalina danica Brotz., Cibicidoides burlingtonensis (Jenn.), Pararotalia globigeriniformis (van Bell.) (see table). Also taxonomic composition of BF of the beds is close to that of Danian interregional zone Anomalina danica s. I. of the CCR [9] and zone Cibicidoides lectus characterizing the Pselian Regional Stage of the Dnieper-Donets Depression [80]. This is proved by presence Arenobulimina prestli Reuss., Ataxophragmium frankei Brotz., Anomalina danica Brotz., Gavelinella umbilicata Brotz., Cibicidoides commatus (Moroz.), Intricatus spiropunctatus (Gall. et Morr.), Gyroidinoides octocameratus (Cushm. et Hanna), Pulsiphonina elegans Brotz., Falsoplanulina ekblomi (Brotz.), Pararotalia globigeriniformis (van Bell.), Coleites reticulosus (Plumm.), Rosalina selandiana Poz. et Szc., Reusella paleocenica (Brotz.), Mississippina binkhorsti (van Bell.) and others in BF assemblages of the beds. On my opinion the described BF associations of beds with Cibicidoides commatus and beds with Cibicidoides burlingtonensis should be defined as assemblage-zone Anomalina danica and Cibicidoides commatus characterizing lower part of the Belokamenskian Regiostage in the NPBSR (see fig. 2). Authorship of this zone is preservated after I.D. Konenkova.

BF association of beds with Cibicidina bundensis and Nonion multisuturatum, distinguished by I.D. Konenkova [23, 25, 26, 35, 37] in the south of the eastern and western parts of the NPBSR, reflects shallow-marine depositional environments of peripheral parts of Paleocene sea in late Belokamenskian time. Differing by numerous anomalinids, polymorphinids, rotaliids and miliolids, the complex includes Anomalina danica (Brotz.) ${ }^{\star}$, An. burlingtonensis (Brotz.), An. ekblomi (Brotz.) ${ }^{\star}$, An. simplex (Brotz.), Cibicides sahlstromi Brotz., C. bundensis van Bell.*, C. succeedens Brotz., Nonion graniferum (Terg.), Nonion multisuturatum van Bell., Eponides toulmini Brotz., Globorotalites lobata Brotz., Rosalina koeneni Brotz., R. selandiana Poz. et Szc., Rotalia lithothamnica Uhlig. katchanensis Schutzk., Pararotalia globigeriniformis (van Bell.), P. macheili Loebl. et Tapp., P. scabrosa Konen., Proteelphidium sublaeve (ten Dam.), Elphidiella prima (ten Dam.), Lamarckina rugulosa (Plumm.), Reussella paleocenica (Brotz.) and others. This assemblage contains characterizing species of the Upper Belokamenskian Regional Substage of the southern Ukraine (marked by $\left({ }^{*}\right)$ in the list). The beds also contain calcareous nannoplankton of zone NP $5[5,6]$, characterizing the same stratigraphic level.

Author's notes. Taking into account stratigraphic position of beds with Cibicidina bundensis and Nonion multisuturatum in the Lower Paleocene section of the south of NPBSR and data on calcareous nannofossils, these beds should be considered as the most shallow-water layers of the Upper Belokamenskian Regional Substage (see fig. 2) and probable stratigraphic analogue of Selandian interregional zone Pyramidina crassa of in the CCR [9]. 
Kachian Regional Stage. Up to the sixties years of the last century in the NPBSR the Paleocene deposits had been considered as undivided [10, 18, 40, 58]. Further Ye.Ya. Kraeva, I.D. Konenkova and A.M. Voloshina's investigations have proved Upper Paleocene by small foraminifera in the region. These researchers distinguished two separate foraminifera associations characterizing the section: the first known as "anomalinids complex" (beds with Anomalina fera and Pulsiphonina prima below in the text) and the second - "complex with arenaceous foraminifera" (beds with Bolivinopsis spectabilis below in the text).

Beds with Anomalina fera and Pulsiphonina prima. A.P. Pechenkina [40] was the first who determined Paleocene foraminifera assemblage with dominating anomalinids and Siphonina from borehole 1 (Mirnoe) drilled not far from Odessa (the southwestern part of the NPBSR). She noted that this assemblage is distinguished by numerous Anomalina danica (Brotz.), An. acuta Plumm., frequent An. praeacuta Vass., Siphonina prima Plumm., rare An. grosserugosa (Guemb.), Eponides umbonatus (Reuss), Angulogerina wilcoxensis (Cushm. et Pont.) and sporadic Ammodiscus incertus (Orb.), Bolivinopsis spectabilis Grzyb., Nodosaria affinis Orb., Dentalina approximata Reuss, Eponides lunatus Brotz., Gyroidina globosa (Hag.), Pullenia quinqueloba Reuss, Asterigerina norvaugi Brotz., Cibicides favorabilis Vass., C. aff. incognitus Vass., etc.

In boreholes drilled in the western part of the NPBSR Ye.Ya. Kraeva [58] described Paleocene "anomalinids complex" consisting of Heterostomella gigantica Subb., Anomalina danica Brotz., Cibicides proprius (Brotz.), C. favorabilis Vass., Siphonina prima Plumm., Alabamina wilcoxensis Toulm., etc.

For Upper Paleocene deposits of the Near-Sivash area A.M. Voloshina [103] indicated BF assemblage with numerous large arenaceous foraminifers Lituoloba taylorensis paleocenica Wolosh., Paragaudryina gigantica (Subb.) and secreted foraminifers Cibicides hemicompressus Moroz., C. commataeformis N. Byk. (msc.), Karreria fallax Reuss.

I.D. Konenkova [21, 24, 27, 28] gave detailed description the "anomalinids complex" and its distribution in Upper Paleocene of the NPBSR. According her this BF assemblage is distinguished by numerous anomalinids Anomalina fera Schutz., An. danica Brotz., Cibicides proprius Brotz., C. aff. faraonis Le Roy, C. sahlstromi Brotz., C. hemicompressus Moroz., Gavelinella limbata Olss., and also Heterostomella gigantica Subb., Vaginulina robusta Plumm., Pulsiphonina prima (Plumm.), P. elegans Brotz., Parella convexa Olss., Globorotalites lobata Brotz., Pseudoparella minuta Olss., Stensioina caucasica (Subb.), Buliminella parvula Brotz., Bolivina selmensis Cushm., Spirobolivina scanica (Brotz.). She described two foraminifera associations characterizing "anomalinids complex": the first with dominating Pulsifonina and numerous Anomalina, Cibicides; the second with dominating Anomalina and Cibicides, numerous Pulsiphonina, few agglutinated forms.

In the NPBSR the beds with "anomalinids complex" correspond to planktic foraminifera zone Acarinina subsphaerica [24, 26, 27] and calcareous nannofosslis of zonal interval NP 6-NP 8 $[5,6]$ characterizing the Kachian Regiostage.

Author's notes. These BF assemblages contain index-species Anomalina fera Schutz. of the Kachian Regiostage the southern Ukraine. I propose to rename the "anomalinids complex" as assemblage-zone Anomalina fera and Pulsiphonina prima and preservate authorship I.D. Konenkova. Small BF of zone Anomalina fera and Pulsiphonina prima, characterizing the Kachian of the NPBSR, are known from Paleocene deposits of the CCR [9,66]. But such species as Anomalina fera Schutzk., Asterigerina norvangi Brotz., Angulogerina wilcoxensis Cushm. et Appl., Sporobolivina scanica (Brotz.) permit to define Thanetian zone Anomalina fera of the Bakhchisarai stratotype region in Crimean Peninsula [9]. Thus, according to modern biostratigraphic ideas [9, 39] zone Anomalina fera and Pulsiphonina prima of the NPBSR should be regarded as stratigraphic analogue of Thanetian interregional zone Karreriella zolkaensis of the CCR (see fig. 2).

Beds with Bolivinopsis spectabilis. From Upper Paleocene deposits in borehole 2-p Chaplinka (the Near-Sivash area) A.M. Voloshina [103] reported arenaceous foraminifera assemblage similar to that one in the Kerch Peninsula. It consists of Rhabdammina maxima 
(Fridb.), Rh. cylindrica Glaessn., Rhizammina indivisa Brady, Bathysiphon nodosariaformis Subb., Nodellum velascoense (Cushm.), Trochamminoides coronatus (Brady), Tr. irregularis White, Haplophragmoides valteri (Grzyb.), Ammodiscus incertus Cushm. et Jarv., Glomospira charoides (Park. et Jin.), Bolivinopsis spectabilis (Grzyb.), Matanzia paleocenica (Hofk.), others.

At the same time in the Upper Paleocene section of the NPBSR above the beds with "anomalinids complex" (zone Anomalina fera and Pulsiphonina prima here) I.D. Konenkova [21, 24, 27, 35] distinguished association with dominating but non numerous arenaceous foraminifera Rhabdammina indivisa Brady, Rh. cylindrica Glaessn., Ammodiscus incertus (Orb.), Haplophragmoides kubanensis Schutzk., H. walteri (Grzyb.), H. tenuis Cushm., Glomospira charoides (Park. et Jon.), Bolivinopsis spectabilis (Grzyb.), rare sporadic secreted foraminifera Anomalina fera Schutzk., Cibicides proprius Brotz., Pulsiphonina prima (Plumm.), Pullenia quinqueloba Reuss, Spirobolivina scanica Brotz., etc. She named this association as "complex with Bolivinopsis spectabilis" [26, 27].

In the NPBSR the described beds correspond to planktic foraminifera zone Acarinina acarinata [26, 27] and calcareous nannofossils zone NP $9[5,6]$, characterizing upper part of the Kachian Regiostage the southern Ukraine.

Author's notes. On my opinion BF association of the beds should be considered as assemblage-zone Bolivinopsis spectabiling characterizing the upper Kachian Regiostage in the NPBSR (see fig. 2). Authorship of this zone is preservated after I.D. Konenkova. Due to presence Rhizammina indivisa Brady, Bathysiphon nodosariaformis Subb., Nodellum velascoense (Cushm.), Haplophragmoides kubanensis Schutzk., H. tenuis Cushm., H. walteri (Grzyb.), Repmanina charoides (Park. et Jon.), Trochamminoides irregularis White, Bolivinopsis spectabilis (Grzyb.), Bol. kurtishensis Balakhm., Marsonella indentata (Cushm. et Jon.), Anomalina fera Schutzk., Cibicidoides proprius (Brotz.), Pulsiphonina prima (Plumm.), Stensioina caucasica (Subb.), Reussella paleocenica Brotz., Sporobolivina scanica Brotz., the zone Bolivinopsis spectabilis of the NPBSR is regarded as stratigraphic shallow-water analogue of Thanetian interregional zone Karreriella zolkaensis of the CCR [9].

Eocene. A.M. Voloshina, A.P. Pechenkina, Ye.Ya. Kraeva, N.G. Savenko and I.D. Konenkova's investigations had proved the Lower, Middle and Upper Eocene by small foraminifera up to the middle seventies of the last century in the NPBSR. M.V. Yartseva had done the Middle and Upper Eocene by BF in depressions of the southern slope the US up to the sixties years of the last century. The most rich, various and numerous BF assemblages characterize the Middle (Novopavlovkian Regiostage) and Upper (Almian Regiostage) Eocene deposits of the region. In the NPBSR the deposits of upper part of Kumian Regiostage contain, in the main, radiolarians, spongue spicules and rare, sporadic BF shells Baggina iphigenia (Sam.), Planulina aff. venezuelana Nutt., Spiroplectammina vicina Erem. and small arenaceous foraminifers [64]. This association do not considers in the article.

Bakhchisaraian Regional Stage. In the south of NPBSR three BF assemblages are known from the Lower Ypresian.

From borehole Chaplinka (the Near-Sivash area) A.M. Voloshina [10] described association consisting of predominately arenaceous foraminifera Rhabdammina indivisa Brady, Proteonina complanata (Fr.), Reophax duplex Grzyb., Ammodiscus glabratus Cushm., Spiroplectammina clotho Grzyb., Sp. rosula Her., Sp. aff. dentata (Alth.), Frankeina aff. taylorensis Cushm. et Wall., Textularia agglutinans Orb., Trochammina advena Cushm., Gaudryina rugosa Orb., Heterostomella gigantica Subb., Clavulina angularis Orb., Karreriella eggeri Finlay and non numerous secreted forms Bulimina aksuatica Moroz., Bolivina antegressa Subb., Angulogerina angulosa (Will.). From the same stratigraphic interval in borehole 1-p Armyansk (the north of Crimean Plain) E.K. Schutzkaya [89] also reported Ammomarginulina sp., Sp. eocaenica Cushm., Reophax sp., Haplophragmoides sp., Glomospira charoides (Park. et Jon.).

Another, the second, BF assemblage was determined by I.D. Konenkova [27, 33] in boreholes drilled near Novo Kievka village and Mayachka of the Kherson area. It includes Ammodiscus incertus (Orb.), Glomospira charoides (Park. et Jon.), Textularia varians Glaessn., Gaudryina navarroana Cushm.*, Dorothia postbuletta Balakhm., Marginulina eofragaria 
Balakhm.*, M. mexicana Cushm., Nodosaria affinis Reuss, N. latejugata (Guemb.), Anomalina granosa (Hantk.), An. acuta Plumm., Cibicides beatus Martin*, C. eocaenus (Guemb.), Asterigerina bartoniana (ten Dam). Previously similar BF association O.K. KaptarenkoChernousova had identified in borehole near Novo-Alekseyevka of the Henichesk area [15, 33]. This BF assemblage includes characterizing species, marked by $\left(^{*}\right)$ in the list, of the Bakhchisaraian Regiostage of the southern Ukraine.

Deposits with the described BF assemblage correspond to planktic foraminifera of zone Morozovella subbotinae s. I. [27,33] and calcareous nannofossils zone NP $11[5,6]$, characterizing the Bakhchisaraian Regiostage.

From beds with Assilina placentula E.K. Schutzkaya [89] determined shallow-water BF association with Marginulina fragaria (Guemb.), Cibicides beatus Martin, C. productus (Terq.). Planktic foraminifera of the beds, indicating the uppermost part of zone Morozovella subbotinae s. I., and calcareous nannofossils, corresponding to zone NP 12 [5, 6], characterize upper part of Bakhchisaraian Regiostage.

Author's notes. BF association of the Bakhchisaraian deposits of the NPBSR consists of species known from Paleocene of the CCR and those ones appearing in Eocene, namely Marginulinopsis eofragaria Balakhm., Nodosaria affinis Reuss, Heterolepa eocaena (Guemb.), Cibicidoides beatus (Martin), Asterigerina bartoniana (ten Dam), Bulimina aksuatica Moroz. Also this association includes index-species of Lower Ypresian interregional zone Pseudogaudryina externa of the CCR [9] (see fig. 2), which was previously defined as Gaudryina navarroana Cushm. [9]. Species Pseudogaudryina externa Bugr., Marginulinopsis eofragaria Balakhm. and Cibicidoides beatus (Martin) constitute characteristic BF association the Bakhchisaraian Regiostage in the NPBSR [64, 90] (see table).

Simferopolian Regional Stage. Up to the seventies of XX century from Simferopolian deposits of the NPBSR three foraminifera assemblages, from deep-water to the most shallow-water, had been distinguished.

The first BF assemblage from Simferopolian deposits of the region is connected with beds with large foraminifers, Acarinina bullbrooki, Morozovella aragonensis [64]. Due to investigations of A.M. Voloshina [10], A.P. Pechenkina [40], I.D. Konenkova [27], E.K. Schutzkaya [89] the complex with dominating planktic foraminifera of zonal interval Morozovella aragonensis Acarinina bullbrooki and accompanying benthic species Clavulina golubjatnikovi Schutzk., Pseudogaudryina pseudonavarroana (Balakhm.), Heterostomella dalmatina (Liebus), Marsonella indentata (Cushm. et Jarv.), Spiroplectammina carinatiformis Moroz., Gyroidina micheliniana Orb., Anomalina acuta Plumm., An. granosa (Hantk.), An. ammophilla Guemb., Cibicides perlucides Nutt., C. eocaenus Guemb., C. ungerianus Orb. was determined in the south of NPBSR

Author's notes. The assemblage includes characterizing species of the Simferopolian Regiostage of the southern Ukraine (see table), namely Pseudogaudryina pseudonavarroana (Balakhm.), Falsoplanulina ammophila (Guemb.), and characterizing species of upper Ypresian - lower Lutetian interregional superzone Pseudogaudryina pseudonavarroana of the CCR [9], namely Spiroplectammina carinatiformis Moroz., Pseudogaudryina pseudonavarroana (Balakhm.), Clavulinoides golubjatnikovi Schutzk., Paragaudryina dalmatina (Liebus), Heterolepa eocaena (Guemb.) (see fig. 2).

The second BF assemblage. Relatively more shallow-water foraminifera associations characterize beds with Nummulites distans widely spreading in the NPBSR [18, 23, 34, 35, 40, $52,100]$. Ye.Ya Kraeva [49] gave detailed characteristic the associations with BF prevailing over planktic foraminifera. She noted that foraminifera complex of the nummulitic beds are changeable both systematic composition and number of specimens of each species. The complex includes Clavulinoides australis Balakhm. et Sapers., Articulina terquemi Cushm., Marginulinopsis decoratus (Reuss), Lenticulina laticostata (Tutkow.), L. arcuato-striata (Tutkow.), Dentalina bulbosa Halk., Anomalina acuta acuta (Plumm.), Heterolepa eocaena (Guemb.), Asterigerina rotula Kaufm., As. stelligera Kraeva, Siphonina lamarckana Cushm., S. kaptarenkae Kraeva, Alabamina tonica Kraeva, Al. wilcoxensis Toulm., Svratkina perlata (Andr.), Cibicides westi arguta 
(N. Byk.), C. hadjibulakensis N. Byk., C. carinatus (Terq.), C. disjunctus (Terq.), Hanzawaia producta (Terq.), Karreria fallax Rzeh., Nonion ex gr. graniferum (Terq.), Pararotalia trochidiformis (Lam.), Reusella limbata (Terq.), Uvigerina proboscidea Schwag., Angulogerina muralis Terq., Bolivina brabantica Kaasch., etc. In the NPBSR the beds with Nummulites distans are characterized by planktic foraminifera of zonal interval Morozovella aragonensis (upper part) Acarinina bullbrooki [27, 45] and calcareous nannofossils of NP 13 and NP 14 zones [6, 113], defining the Simferopolian Regiostage of the southern Ukraine.

The third BF assemblage has been described by Ye.Ya. Kraeva [49], who marked that the most shallow-water BF associations of simferopolian nummulitic beds in the NPBSR differ by pure systematic composition but abundant specimens Cibicides disjunctus (Terq.), Asterigerina rotula Kaufm., As. stelligera Kraeva, Alabamina tonica Kraeva, Rotalia ex gr. trochidiformis (Lam.), Reussella limbata (Terq.), others.

Author's notes. The small BF assemblages of the beds with Nummulites distans of Simferopolian Regiostage the NPBSR I propose to distinguishe as assemblage-zone Vaginulinopsis decorata, Asterigerina stelligera (see fig. 2). The zone includes characterizing BF species determing this regiostage in the region (see table). Due to presence Robulus laticostatus (Tutkow.), Vaginulinopsis decorata (Reuss), Cibicidina dampelae (N. Byk. et Chram.), Falsoplanulina ammophila (Guemb.), Asterigerina stelligera Kraeva, Siphonina kaptarenkae Kraeva, Eponides polygonus (Le Calvez), Alabamina tonica Kraeva, Baggina valvulineriaformis (N. Byk.), Cancris plana (Balakhm.), Bulimina aksuatica Moroz., Kolesnikovella elongata (Halk.) this zone Vaginulinopsis decorata, Asterigerina stelligera should be considered shallow-water stratigraphic analogue of upper Ypresian - lower Lutetian interregional superzone Pseudogaudryina pseudonavarroana of the CCR [9].

Novopavlovkian Regional Stage. Beds with Robulus kuberlinus and Uvigerina bykovae ucrainica. These beds were firstly distinguished by Ye.Ya. Kraeva [97] as "zone Hopkinsina bykovae ukrainica" corresponding to sediments of the Kuberla Horizon of the NPBSR and spreading into the southern slope of US. In the Stratigraphic Scheme of Ukraine [64, 90] the described BF assemblage is named beds with Lenticulina kuberlina and Hopkinsina bykovae ukrainica of the lower Novopavlopkian Regional Subhorizon.

In the mentioned article Ye.Ya. Kraeva [97] gave detailed description of zonal BF assemblage consisting of Paragaudryina pseudonavarroana Balakhm., Heterostomella dalmatina (Liebus), Clavulina cylindrica Hantk., Cl. szaboi (Hantk.), Lenticulina romeri (Reuss), L. laticostata Tutkow., L. kuberlina J. Nik., Anomalina acuta acuta Plumm., An. neelyi Jenn., Cibicidoides biumbonatus A. et K. Furs., Alabamina wilcoxensis Toulm., Pseudoparella culter (Park. et Jon.), Siphonina kaptarenkae Kraeva, Cibicides ammophylus (Guemb.), C. westi westi Howe, C. ungerianus (Orb.), Asterigerina stelligera Kraeva, As. rotula Kaufm., Bifarina millepunctata Tutkow., Bulimina arostrata Balakhm., Bul. aff. mitgarziana Balakhm., Hopkinsina bykovae ukrainica Kraeva, Uvigerina proboscidae Schwag., Angulogerina elongata (Halk.). She marked [97] that the most of foraminifera of the beds with Hopkinsina bykovae ukrainica are known from Simferopolian Horizon and Kuberla Horizon (now Lower Novopavlovkian Regional Substage). She determined lower limit of the beds by appearance of Hopkinsina bykovae ucrainica Kraeva, Bulimina arostrata Balakhm., Siphonina kaptarenkae Kraeva [52, 93. To my mind in some sections the lower part of beds may correspond to upper part of Simpheropolian Regiostage. In borehole Mirnoe, drilled not far from Odessa, Ye.Ya. Kraeva and T.A. Menkes [109] determined foraminifera assemblage of the Kuberla Horizon in interval $452-448 \mathrm{~m}$ from sandy marls containing large foraminifera of beds with Nummulites distans indicating Simferopolian Regiostage. Upper limit of the beds with Hopkinsina bykovae ukrainica Ye.Ya. Kraeva determined by appearance Textularia carinatiformis Moroz., Bulimina sculptilis Cushm., Uvigerina hispida Schwag. and planktic foraminifera Globigerinoides subconglobatus Schutzk., Hantkenina alabamensis Cushm. marking the Keresta Horizon (now the Upper Novopavlovkian Regional Substage).

Researchers also noted increasing thickness of beds with Hopkinsina bykovae ukrainica of the Kuberla Horison from the south to north in the NPBSR [52, 67, 97]. 
It is interesting to note that in Ye.Ya. Kraeva's publications of middle 50-s - beginning 60-s years of the XX century this BF assemblage has not been distinguished. It was included into "lagenids-globorotaliids zone" in the Tokmak-Melitolpol area of the eastern part of the NPBSR, "zone Hantkenina alabamensis (globorotaliids)" in the Odessa-Kherson area of the western part of the NPBSR [41, 43, 44] or has been considered in Middle Eocene deposits (now Simpheropolian Regiostage).

N.G. Savenko [83] distinguished foraminifera assemblage of the Kuberla Horizon in the NPBSR as biostratigraphic "zone Lenticulina kuberlina, Acarinina pentacamerata" in boreholes of the central and eastern parts of the region, "zone Acarinina pentacamerata, Acarinina interposita" of the south-west of the region. She determined that in foraminifera assemblages of the Kuberla Horizon in the north of NPBSR the secreted benthic species prevail over planktic and arenaceous ones. Among BF representatives Nodosariidae, Asterigerinidae and Buliminidae dominate. The most numerous are Textularia pishvanovae A. et K. Furs., Lenticulina kuberlina J. Nik., Cibicides perlucides Nutt. var. kasahstanensis J. Nik., Bulimina arostrata Balakhm., Hopkinsina bykovae ukrainica Kraeva, Uvigerina proboscidae Schwag.

Due to investigations of Ye.Ya. Kraeva [45, 55, 85], Yu.P. Nikitina [65], N.G. Savenko [11, $82,83,100,101]$ and I.D. Konenkova [22, 35] systematic composition of the beds was completed by Marsonella indentata (Cushm. et Jarv.), Hydromylina rutteni Puyt., Anomalina postvulgaris J. Nik., Cibicides perlucides (Nutt.), Heterolepa pygmeuformis (Kraeva), H. porosus (Kraeva), Eponides jacksonensis Cushm., Virgulina dibollensis Cushm. et Appl., Sporobulimina eocaena N. Byk., Bulimina mitgarziana Balakhm., Candella ignara N. Byk.

As a result restudying samples from boreholes drilled on the Odessa area Ye.Ya. Kraeva and T.A. Menkes [109] redefined BF of the Kuberla Horizon and supplemented the species composition with Textularia pishvanovae (A. et K. Furs.), Clavulinoides golubjatnikovi Schutzk., Marginulina fragaria (Guemb.), Lenticulina dimorpha (Tutkow.), Anomalina granosa (Hantk.), Brotzenella pseudoacuta (Nakk.), Cibicidoides hadjibulakensis (N. Byk.), Heterolepa eocaena (Guemb.), Eponides subumbonatus Mjatl., Alabamina tonica Kraeva, Cibicides lobatulus (Walk. et Jac.), Trifarina bradyi Cushm., Dymia idnara N. Byk.

These beds spread on the south of US where they are known as "light marls with large lagenids, buliminids and Clavulina". Previously this BF assemblage was described firstly by M.V. Yartseva as "complex with large lagenids, buliminids, anomalinids and rotaliids" from lightyellow marls of the middle part of the Kiev Suite in the Ingulets river basin [71]. Researcher noted that planktic foraminifera association of the marls is characteristic for "zone Globigerinoides conglobatus" of the northern Fore-Caucasus (now - Globigerinatheka subsonglobata, Hantkenina alabamensis Zone of the Upper Novopavlovkian Regional Substage in the southern Ukraine).

Later Ye.Ya. Kraeva [111] attributed the light marls with Spiroplectammina carinatiformis Mor., large lagenids, buliminids of the south of the US to the Keresta Horizon.

M.V. Yartseva, Ye.Ya. Kraeva [108] have revised foraminifers of Eocene sediments the southern slope of US. They distinguished the described BF association as the fourth complex with numerous and diverse lagenids and buliminids, large arenaceous Clavulina and Clavulinoides. Researchers correlate it with Globigerina turkmenica and Globigerina instabilis Zone of the Kuma Horizon and perhaps with upper part of lone Globigerapsis subconglobatus and Hantkenina alabamensis of the Keresta Horizon.

Based on planktic foraminifera of zone Globigerinatheka subconglobata T.S. Ryabokon [75] precised stratigraphic position of that BF complex and attributed the beds to the Keresta Horizon (now the Upper Novopavlonkian).

So, in the NPBSR the beds with Robulus kuberlinus, Uvigerina bykovae ukrainica correspond to planktic foraminifera zone Acarinina rotundimarginata [52, 55, 97]. On the southern slope of US the beds are some younger and correspond to zone Globigerinatheka subconglobata, Hantkenina alabamensis $[75,108]$. In the lower part of the beds' section the large foraminifera beds with Nummulites variolarius are distinguished. Calcareous nannofossils of zonal interval NP 15-NP 16 characterize beds with Robulus kuberlinus, Uvigerina bykovae ukrainica. 
Author's notes. Small BF assemblage of the desribed beds should be considered as assemblage-zone Robulus kuberlinus, Uvigerina bykovae ukrainica, characterizing the Novopavlovkian Regiostage in the NPBSR (fig. 3). Due to presence Spiroplectammina carinatiformis Moroz., Sp. pishvanovae A. et K. Furs., Paragaudryina dalmatina (Liebus), Pseudogaudryina pseudonavarroana Balakhm., Robulus kuberlinis (J.Nik.), R. dualis Bugr., R. laticostatus (Tutkow.), Marginulinopsis fragaria (Guemb.), Cibicidoides biumbonatus A. et K. Furs., Cib. hadjibulakensis (N. Byk.), Heterolepa eocaena (Guemb.), Alabamina tonica Kraeva, Siphonina kaptarenkae Kraeva, Falsoplanulina ammophila (Guemb.), Asterigerina stelligera Kraeva, Sporobulimina eocaena N. Byk., Uvigerina haspida Schwag., Uv. costellata Moroz., Trifarina bradyi Cushm., Dymia labrum (Subb.), Loxostomoides millepunctatus (Tutkow.), zone Robulus kuberlinus and Uvigerina bykovae ukrainica of the NPBSR corresponds to Lutetian interregional zone Uvigerina costellata of the CCR [9]. On my opinion deposits of this zone reflects certain shelf facies of the Eocene basin within the NPBSR in Lutetian time.

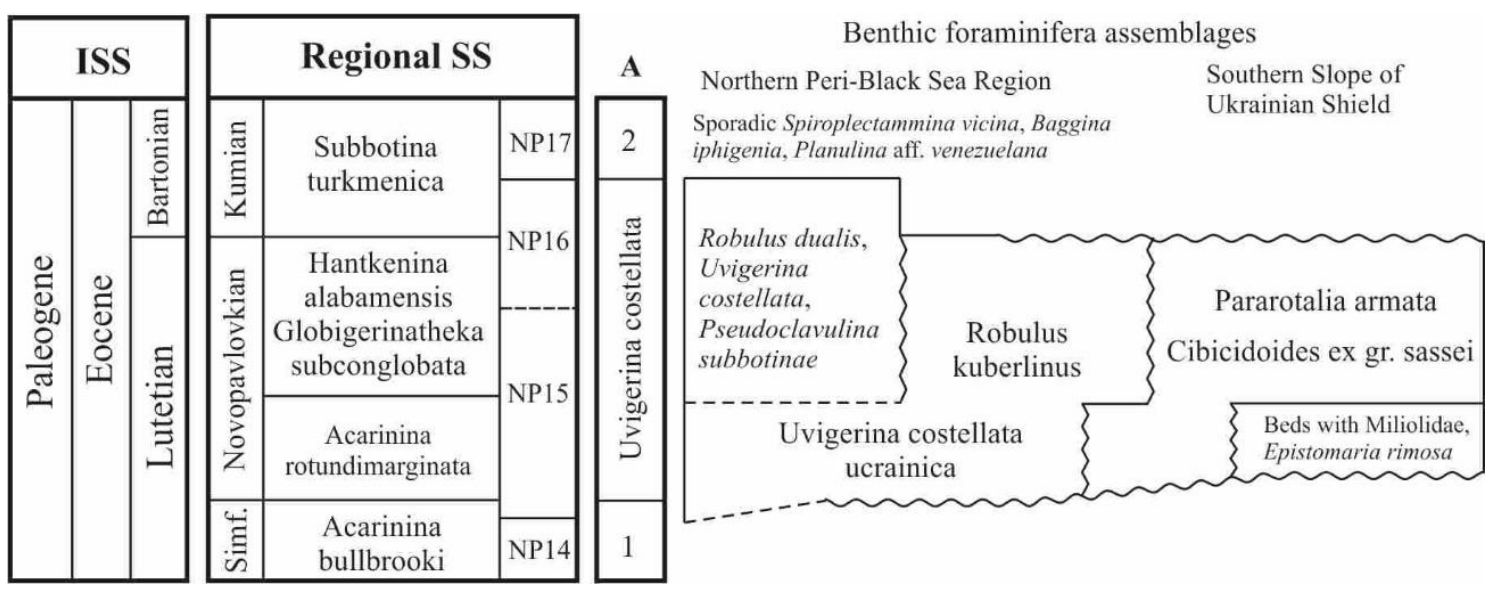

Fig. 3. Sequence and space-time relationships of small benthic foraminifera assemblages in Middle Eocene of the southern Ukraine

A - interregional benthic foraminifera zones of the Crimea-Caucasus Region [9, 39]: 1 - zone Pseudogaudryina pseudonavarroana; 2 - zone Haplophragmoides orfaensis

Small BF assemblages of beds with Nummulites variolarius. The first mentions about small BF of Eocene deposits of the southern slope of US are in articles of O.K. KaptarenkoChernousova [16] and M.V. Yartseva [104]. M.V. Yartseva [104] described distribution of foraminifera in Eocene section of the Nikopol area. She noted that beds with Ostrea are characterized by abundant Cibicides carinatus (Terq.), Rotalia armata (Orb.), decreasing quantity of miliolids and discorbiids, mass Camerina sp. (= Nummulites sp.). She correlated these beds with Ledian stage of Europe. In her later publications [71, 106] M.V. Yartseva gave more detailed characteristic of Eocene deposits with small nummulitids of the southern slope of US (basins of the Basavluk, Solenaia and Ingulets rivers). After M.V. Yartseva the characteristic feature of the beds is the presence large foraminifera Nummulites variolarius Lam., Num. incrassatus de la Harpe. In general, the small BF assemlage of these beds is distinguished by Asterigerina, Anomalinidae, C. carinatus (Terq.), C. sassei (Cole), Rotalia armata (Orb.).

In following years, mention and description of BF assemblage of beds with Nummulites variolarius, Num. incrassatus of the region are present in publications of Yu.P. Nikitina [65], Ye.Ya. Kraeva [111], I.D. Konenkova [7] and others.

Yu.P. Nikitina [65] for the southern slope of US reported two shallow-water associations: the first with Rotalia armata (Orb.), large Anomalinidae, Asterigerinidae; the second with numerous Lenticulina inornata (Orb.), Cibicides kasahstanensis J. Nik., C. ex gr. sassei Cole, C. ex gr. rzehaki (Grzyb.), Nonion umbilicatulum (Walk. et Jack.), Rotalia armata (Orb.), Asterigerina sp., Virgulina dibollensis Cushm. et Appl. She correlated these BF associations with "lagenids- 
globorotaliids zone" of the Tokmak-Melitopol area (the eastern part of the NPBSR) [41, 44] and with the Keresta Horizon of Crimean Peninsula.

Ye.Ya. Kraeva [111] described the assemblage under consideration of the southern slope of the US as rich association of shallow-water foraminifers with abundant miliolids, nonionids, Pararotalia armata (Orb.), Cibicides sp., nummulitids.

Based on restudying foraminifers of Eocene deposits of the southern slope of the US, M.V. Yartseva, Ye.Ya. Kraeva [108] identified BF association of beds with Nummulites variolarius as "the third complex" with numerous small Num. gandinus Rz. (= Num. variolarius var gandina Rz.). In this association along with many species of "the second complex" (assemblage with miliolids and Epistomaria semi-marginata) are constantly present Clavulina parisiensis Orb., Eponides polygonus Le Calv., Pararotalia armata (Orb.), Cibicides robustus Le Calvez, Cycloloculina costellata (Terq.), Asterigerina sp., Robertina ovigera (Terq.), Angulogerina muralis (Terq.), rare miliolids. For "the third complex" M.V. Yartseva, Ye.Ya. Kraeva also designated Quinqueloculina nicopolica Jarz., Triloculina trigonula (Lam.), Tr. soljenica Jarz., Spiroloculina carinata Le Calvez, Sp. contorta Le Calvez, Discorbis rotata (Terq.), Eponides schreibersi (Orb.), Rosalina limbata (Terq.), Cancris subconicus (Terq.), Cibicides carinatus (Terq.), Nonion affine (Reuss), N. commune (Orb.), Elphidium hiltermanni Hagn., Tubuligenerina tubulifera (Park. et Jon.), Bolivina crenulata Cushm., others. Researchers considered deposits containing "the third complex" of BF an analogue the Lutetian and dated them middle Eocene.

I.D. Konenkova [13], L.A. Digas [63], T.S. Ryabokon [74, 76, 77, 114], T.A. Ivanova [7] also have studied taxonomic composition of association of small BF of the beds with Nummulites variolarius of the southern slope of US. They supplemented the species composition of beds with Nummulites variolarius with Textularia conica Orb., Spiroplectammina haueri (Orb.), Robulus crassus (Orb.), $R$. inornatus (Orb.), $R$. laticostatus (Tutkow.), Dentalina acuta Orb., D. badenensis (Orb.), D. inornata Orb., Nodosaria spinescens Reuss, Anomalinoides alazanensis (Nutt.), Cibicidoides aff. extremus (Schutzk.), Cib. karpaticus Mjatl., Cib. ex gr. sassei (Cole), Cib. hadjibulakensis (N.Byk.), Heterolepa eocaena (Guemb.), H. pygmea (Hantk.), H. porosa (Kraeva), Hanzawaia producta (Terq.), Cycloloculina eocaenica Terq., C. punctata Terq., C. flabellum Terq., Melonis umbilicatulus (Orb.), M. dosularensis (Chalil.), Pullenia quinqueloba Reuss, Valvulineria palmarealensis (Nutt.), Asterigerina rotula Kaufm., As. stelligera Kraeva, As. jartzevae Konen, Eoeponidella lobata Sztrakos., Ammonia stellata (Kraeva), Am. proprinqua (Reuss), Pararotalia spinigera Le Calvez, P. audouini (Orb.), Porozononion subnodosum (Munst.), Canalifera aff. microgranulosa (Gall. et Wiss.), Bulumina woodwardi Tutkow., Fursenkoina dibollensis (Cushm. et Appl.), Kolesnikovella ignara N.Byk., Reussella terquemi Cushm., $R$. obtusa (Terq.), Lamarckina ovula Le Calvez, etc. T.S. Ryabokon [75-77] described diversity of small BF associations of these beds differing by dominant Pararotalia, Melonis, Robulus, Polymorphinidae, Cibicidae.

Author's notes. Small BF assemblages of beds with Nummulites variolarius on the southern slope of US should be regarded as assemblage-zone Pararotalia armata, Cibicidoides ex gr. sassei. Due to presence Robulus laticostatus (Tutkow.), Cibicidoides carinatus (Terq.), Cib. hajibulakensis N. Byk., Heterolepa eocaena (Guemb.), Hanzawaia producta (Terq.), Asterigerina rotula Kaufm., A. stelligera Kraeva and other species, BF assemblages of beds with Num. variolarius (zone Pararotalia armata, Cibicidoides ex gr. sassei) of depressions of the southern slope of US are similar to BF complex of beds with Num. distans (zone Vaginulinopsis decorata, Asterigerina stelligera of the Simpheropolian Regiostage in the article). But deposists of zone Pararotalia armata, Cibicidoides ex gr. sassei are some younger because they contain middle-upper Lutetian large foraminifera of zone Num. variolarius [112], rare planktic foraminifera of zone Acarinina rotundimarginata [7] and calcareous nannofossils of zonal interval NP 15-NP 16 $[7,76,94]$, determing the Novopavlovkian Regiostage of the southern Ukraine. Marking shallowmarine depositional environments of the Eocene basin within the southern slope of US in the Novopavlovkian time (middle Eocene), zone Pararotalia armata, Cibicidoides ex gr. sassei is an stratigraphic analogue of zones Robulus kuberlinus, Uvigerina bykovae ukrainica of the NPBSR (see fig. 3). This conclusion is proved by common species Spiroplectammina pishvanovae A. et 
K. Furs., Robulus crassus (Orb.), R. laticostatus (Tutkow.), R. inornatus (Orb.), R. pseudoromeri Schwemb., Anomalinoides alazanensis (Nutt.), Cibicidoides karpaticus Mjatl., C. biumbonatus A. et K. Furs., C. hadjibulakensis N.Byk., Heterolepa eocaena (Guemb.), H. porosa (Kraeva), Melonis umbilicatulus (Orb.), M. affine (Reuss), Pullenia quinqueloba Reuss, Ammonia ? stellata (Kraeva), Asterigerina stelligera Kraeva, Sporobulimina eocaena N. Byk., Fursenkoina dibollensis (Cushm. et Appl.).

Beds with Miliolidae and Epistomaria rimosa. M.V. Yartseva [104-106] was the first who described association with large and various miliolids, polymorphinids from upper part of "sub-ostrea beds" in the Nikopol section on the southern slope of US. She noted predominance Miliolidae, Elphidium, presence Epistomaria semimarginata (Orb.), Discorbis aff. limbatus (Terq.), Dis. parisiensis (Orb.) in the complex. So M.V. Yartseva [71] named it as "assemblage with abundante miliolids and polymorphinids, with Ep. semimarginata d'Orb" or "grey calcareous clays with Ep. semimarginata".

Later as a result of restudying foraminifera from Eocene deposits of the southern slope of US, M.V. Yartseva and Ye.Ya. Kraeva [108] have distinguished the mentioned BF association as "the second complex" characterizing by abundance Miliolidae and permanent presence Epistomaria rimosa (Park. et Jon.). This complex includes Quinqueloculina nicopolica Jarz., Q. carinata Orb. ${ }^{*}$, Triloculina angularis Orb. ${ }^{*}$, Tr. gibba Orb. ${ }^{*}$, Tr. trigonula (Lam.) ${ }^{*}$, Tr. soljenica Jarz., Spiroloculina carinata Le Calvez*, Sp. tricarinata Terq.*, Sp. contorta Le Calvez*, Sp. perforata Orb.*, Sp. cf. cylindrica Lam.*, Sp. cf. pedum Orb., Articulina ferussaci (Orb.)*, Ar. cf. nitida Orb. ${ }^{*}$, Vertebralina contracta Terq. ${ }^{*}$, V. ex gr. striata Orb.*, Biloculina bulloides $\left(\right.$ Orb. ${ }^{*}$, B. ringans Orb.*, Nodobaculariella jartzevae Bogd., Fissurina orbignyana (Seg.) tricarinata (Terq.)*, Globulina gibba Orb. ${ }^{*}$, Guttulina irregularis (Orb.)*, Anomalina auris Le Calvez ${ }^{*}$, Hanzawaia producta (Terq. $)^{*}$, Cibicides carinatus (Terq.)*, Discorbis alata Le Calvez*, Dis. vesicularis Lam. ${ }^{*}$, Dis. rotata (Terq. ${ }^{*}$, Eponides schreibersii (Orb.), Rosalina limbata Terq. ${ }^{*}$, $R$. ex gr. humilis Le Calvez*, Cancris subconicus (Terq.)*, Valvulineria ex gr. lamellosa Terq.*, Nonion labradoricus Davs., N. ex gr. commune (Orb.), Elphidium hiltermanni Hagn. ${ }^{*}$, El. ex gr. laeve (Orb. ${ }^{*}$, Pararotalia armata (Orb.) ${ }^{*}, P$. inermis (Terq.) ${ }^{*}$, Epistomaria rimosa (Park. et Jon.) ${ }^{*}$, Bulimina ovigera Terq. ${ }^{*}$, Bul. elongata Le Calvez, non Orb. ${ }^{*}$, Buliminella pulchra Terq. ${ }^{*}$, Reusella terquemi Cushm.* Researchers dated the second BF complex late Lutetian based on similar composition of species with the Paris basin (marked by * in the list).

T.S. Ryabokon [75-77] gave historical review of stratigraphical interpretation of beds with miliolids. She supplemented the species composition of the beds with Robulus inornatus (Orb.), Nonion commune (Orb.), Melonis affine (Reuss), M. umbilicatulus (Orb.), Cibicidoides karpaticus Mjatl., Eponides polygonus (Le Calv.), Baggina subconica (Terq.), Neoconorbina orbignyana (Brady), Asterigerina stelligera Kraeva, Cribrononoin onerosum (Bogd.), Porosononion subnodosum (Munst.), Reussella terquemi Cushm., Tubulogenerina tubulifera (Park. et Jon.), Robertina germanica Cushm. et Park., Bolivina crenulata Cushm., etc. Researcher described variety of BF associations namely complex with Miliolidae, complex with Ammonia, complex with Polymorphinidae, complex with Lobatula. T.S. Ryabokon [75] compared the beds with Miliolidae and Epistomaria rimosa the Kuberla Horizon (= Lower Novopavlovkian Regional Substage) of the southern Ukraine. She also confirmed correlation the beds with Miliolidae and Epistomaria rimosa of the Basavluk depression of the southern slope of US with middle-upper Lutetian of the Paris basin. T.S. Ryabokon noted that by taxonomic composition the BF assemblages of the beds differ sharply from known BF associations of middle Eocene deposits the NPBSR and the DnieperDonets Depression. After her the common species with BF association of the Novopavlovkian of the NPBSR are Lenticulina rostellata Kraeva, Cibicidoides hagjibulakensis N. Byk., Heterolepa porosa Kraeva, Asterigerina stelligera Kraeva, As. jartzevae Konen., Cibicidina arguta (N. Byk.), Hanzawaia producta (Terq.), Ammonia? stellata (Kraeva), Kolesnikovella ignara N. Byk., Bolivina arta Mact. Also she noted the predominance Miliolidae, Polymorphinidae.

Author's notes. Beds with Miliolidae and Epistomaria rimosa characterize shallow-marine depositional environments of the Eocene sea within depressions on the southern slope of US in middle Lutetian time (see fig. 3). 
Novopavlovkian - Kumian Regional Stages. BF assemblages with Robulus dualis Bugr., Uvigerina costellata Moroz., Pseudoclavulina subbotinae J. Nik. are connected with marls and clay limestones in section of the south part of the NPBSR. These deposits are accompanied with planktic foraminifera of zone Globigerinatheka subconglobata, Hantkenina alabamensis characterizing Upper Novopavlovkian Regional Substage. Aslo the associations are known from lithologically similar grey-greenish marls with Subbotina turcmenica (Chal.), Acarinina bullbrooki (Bolli) marking the lower part of the Kumian Regiostage in the region. As biostratigraphic unit (zones or beds with foraminifera) these assemlages were not distinguished by prevoius researchers. But similar associations of small BF were described by Ye.Ya. Kraeva [41, 44] in sections of the NPBSR as "lagenids-globigerinids zone" in the Tokmak-Melitopol area, as "zone Globigerina apertura and Hantkenina alabamensis" in the Razdelnaya area and as "globigerinids zone" in the Odessa-Kherson area. Information about taxonomic composition of BF associations of the Keresta and Kuma Horizons also presents in publications of N.G. Savenko [82, 83, 101] and Ye.Ya. Kraeva [53, 55].

The assemblage, be named in the article as beds with Robulus dualis, Uvigerina costellata, Pseudoclavulina subbotinae, includes Spiroplectammina carinatiformis Mor., Sp pishvanovae (A. et K. Furs.), Paragaudryina dalmatina (Liebus.), Gaudryina asiphonia Andr., Clavulinoides szaboi (Hantk.), Pseudoclavulina subbotinae J. Nik.), Robulus dualis Bugr. (= dimorpha (Tutkow.)), $R$. limbosus (Reuss), $R$. laticostatus (Tutkow.), $R$. grodnensis (A. et K. Furs.), Lenticulina parvula Kraeva, Marginulinopsis fragaria (Guemb.), M. pseudosetosa (Moroz.), Frondicularia tenuissima Hantk., Nodosaria bacillum Defr., Siphonodosaria annulifera (Cushm. et Berm.), Anomalinoides affinis (Hantk.), A. alazanensis Nutt., Brotzenella acuta taurica (Sam.), Br. turkmenica Bugr., Cibicidoides perlucidus (Nutt.), Cib. ungerianus (Orb.), Heterolepa pygmea (Hantk.), H. eocaena (Guemb.), H. biumbonata (A. et K. Furs.), Valvulineria palmarealensis Nutt., Gyroidinoides soldanii (Orb.), Svratkina perlata (Andr.), Oridorsalis umbonatus (Reuss), Siphonina kaptarenkae Kraeva, S. subreticulata Mjatl., Alabamina almaensis (Sam.), Al. wilcoxensis Toulm., Falsoplanulina ammophila (Guemb.), F. cushmani (Nutt.), Planulina costata (Hantk.), Bulimina sculptilis Cushm., Bul. aksuatica Moroz., Bul. inflata Seg., Globobulimina ovata (Subb., non Orb.), Fursenkoina dibollensis (Cushm. et Appl.), Uvigerina proboscidea Schwag., Uv. hispida Schwag., Uv. costellata Mor., Uv. jacksonensis Cushm., Uv. cocoaensis Cushm., Bolivina pusilla Schw., B. antegressa Subb., B. microlancetiformis Subb., B. asiatica Moroz., Trifarina bradyi Cushm., Candella labrum (Subb.), Kolesnikovella elongata (Halk.), Angulogerina wilcoxensis Cushm. et Appl., Loxostomoides millepunctatus (Tutkow.), etc.

Author's notes. Presence Spiroplectammina pishvanovae A. et K. Furs., Spiroplectammina carinatiformis Moroz., Pseudoclavulina subbotinae J. Nik., Robulus dualis Bugr., R. laticostatus (Tutkow.), $R$. grodnensis (A. et K. Furs.), Turkmenikaella infans (Kraeva), Brotzenella turkmenica Bugr., Cibicidoides biumbonatus (A. et K. Furs.), Siphonina kaptarenkae Kraeva, Falsoplanulina ammophila (Guemb.), Uvigerina costellata Moroz., Bulimina sculptilis Cushm., B. aksuatica Moroz., Bolivina microlancetiformis Subb., Dymia labrum (Subb.), Trifarina bradyi Cushm., Loxostomoides millepunctatus (Tutkow.) and others proves correspondance the beds with Robulus dualis, Uvigerina costellata, Pseudoclavuluna subbotinae to middle Eocene interregional zone Uvigerina costellata of the CCR and regional zone Robulus dualis of the Russian Platform [9] (see fig. 3).

Almian Regional Stage. Despite numerous and good works on identification and description Upper Eocene foraminifera assemblages of the NPBSR the BF biostratigraphy of Priabonain section remains still non clear and sometimes confuse due to facies diversity of sediments.

Ye.Ya. Kraeva [41, 44], N.G. Savenko [83] have identified three foraminifera assemblages in Upper Eocene of the region. The first complex is connected with relatively deep-water marls and calcareous clays, the second one do with relatively shallow-water clay-silty deposits and the third one - the most shallow-water silty-sandy sediments. But as in these publications and as in others [30, 31, 35, 43, 52, 56, 65, 72, 88, 100, 101, 111] similar BF associations present under different names for various areas. Moreover, foraminifera associations with dominating arenaceous species from the upper part of the Eocene section previously as usual were attributed 
to Lower Oligocene. New data on calcareous nannofossils and dinocysts be obtained from the sections up to the end of XX century have not lead to revision and redefinition stratigraphical position of the foraminifera assemblages.

Due to Ye.Ya. Kraeva, N.G. Savenko, A.P. Pechenkina and I.D. Konenkova's investigations the following BF assemblages may be distinguished today in the Almian Regiostage of the NPBSR, namely the beds with Marginulinopsis infracompressus, the beds with Asterigerina, Nonion, Bolivina, the beds with Eoeponidella lucida and Cibicidoides salensis, the beds with Anomalinacea, Miliolidae, Asterigerina, Pararotalia, the beds with arenaceous foraminifera, the beds with Gaudryinopsis gracilis and Heterolepa almaensis and the beds with Angulogerina transcaspiensis.

Beds with Marginulinopsis infracompressus. Ye.Ya. Kraeva [41, 44] was the first who identified foraminiferal assemblage of relatively deep-water marls of Upper Eocene of the region as "zone with Globigerinoides conglobatus" in sections of the Razdelnaya area (the southwestern part of the NPBSR), the Novo-Alekseevka (the Near Sivash) and Akimovka (the eastern part of the NPBSR). She described these deposits as those with numerous foraminifera, radiolarians and diatoms. After her it is characterized by numerous Globigerinoides conglobatus (Brady) and permanent presence Marginulina infracompressa (Thalm.), Bulimina sculptilis Cushm., Uvigerina densecostata Kapt. (msc.), Uv. costellata Moroz. Later N.G. Savenko [83] has confirmed Kraeva's results and also has marked numerous Bolivina antegressa Subb., various and numerous Nodosaria, Lenticulina, Buliminidae, Anomalinidae for the complex.

Ye.Ya. Kraeva [41, 44] and N.G. Savenko [83] considered this foraminifera assemblage to be an analogue of "zone with large globigerinids and Globigerinoides conglobatus" (syn.: zone Globigerapsis index) of the Alma Regional Horizon of Crimean Peninsula.

Similar BF associations from relatively shallow-water calcareous clay-silty deposits of UpperEocene, the researchers have identified under different names, namely "buliminids zone" in the Bolshaya Belozerka section [41, 44], "zone with Marginulina infracomressa" [41, 43, 44, 52], "zone Marginulina behmi" [83], an analogue of "zone Bolivina" or "horizon with Marginulina" [72], "zone Bolivina" [88, 111] and "zone Bolivina antegressa" [31].

The foraminifera assemblage of relatively shallow-water sediments is distinguished by predominance of benthic species and reduction of planktic ones, disappearance of Globigerinoides conglobatus (= Globigerinatheka tropicalis (Blow et Banner)) upward the section. BF associations of calcareous clay-silty deposits are similar to that of marls.

Ye.Ya. Kraeva [62, p. 7, table] renamed this foraminifera assemblage of Upper Eocene deposits of the NPBSR as "beds with Marginulina infracompressa and Globigerinoides conglobatus". Later L.A. Digas [8] has emphasized that "beds with Marginulina infracompressa Globigerapsis index" in the central and western parts of the NPBSR occur conformable between "zone of planktic foraminifera" (Subbotina turcmenica zone of the Kumian Regional Stage) and "beds with Asterigerina, Nonion, Bolivina, Nummulites" (upper part of the Almian Regional Stage).

Upper Eocene beds with Marginulinopsis infracompressus of the NPBSR include Paragaudryina dalmatina (Liebus), Cyclammina pseudocansellata Chalil., Clavulinoides szaboi (Hantk.), Cylindroclavulina colomi Hagn, Cyl. rudislosta (Hantk.), Marginulinopsis infracompressus (Thalm.), Marginulina behmi Guemb., Brotzenella acuta (Plumm.) taurica (Sam.), Anomalinoides alazanensis Nutt., Cibicidoides ungerianus (Orb.), Cib. perlucidus Nutt., Cib. biumbonatus (A. et K. Furs.), Alabamina almaensis (Sam.), Oridorsalis jacksonensis (Nutt.), O. umbonatus (Reuss), Baggina iphigenia (Sam.), Planulina costata (Hantk.), Bulimina sculptilis Cushm., Bul. aksuatica Moroz., Uvigerina jacksonensis Cushm., Uv. costellata Moroz., Uv. pygmea Orb., Uv. dubia Kraeva, Grammostomum nobilis (Hantk.), Bolivina antegressa Subb., Fursenkoina schreibersiana (Cz.), Globocassidulina globosa (Hantk.) and others [31, 35, $44,52,55,56,59,83,88,100,101]$.

In the eastern part of the Near-Azov Region [31, 54] BF association of beds with M. infracompressus includes, except mentioned species, Ammobaculites grossecameratus TerGrig., Spiroplectammina azovensis J. Nik., Vulvulina eocanena Mont., Frondicularia budensis Hantk., Frondicularia tenuissima (Hantk.), Robulus limbosus (Reuss), Anomalina granosa 
(Hantk.), Cibicidoides bionus (Schutzk.), Cib. kugultaensis (Schutzk.), Cib. cribrosus (A. et K. Furs.), Heterolepa pygmea (Guemb.), Oridorsalis subumbonatus (Mjatl.), Melonis rotulis (Chalil.), Asterigerina falsilocularis Subb., A. crassa-suturata Konen., A. bracteata Konen., Turrilina alsatica Andr., Bulimina truncana Guemb., Neobulimina fraudenta Subb., Tergrigorjanzaella sectile (Ter-Grig.), Uvigerina dubia Kraeva, Uv. gardneri Cushm., Uv. jacksonensis delicatula Kraeva, Angulogerina angulosa (Will.), Rectuvigerina lacera (Subb.), Bolivina simplex Balakhm., B. adziderensis Chalil., B. pseudoaenariensis Mjatl., $B$. reticulataformis Chalil., B. praebinaensis Chalil. carinata Chalil.

In the NPBSR the beds with $M$. infracompressus correspond to Upper Eocene planktic foraminifera zone Globigerinatheka tropicalis s.l. and calcareous nannofossils zonal interval NP 18-NP 19/20 [5, 6, 31, 36, 54, 56, 69, 83, 113] determing the Almian Regiostage of the southern Ukraine.

Author's notes. The described BF assemblage should be considered as assemblage-zone Marginulinopsis infracompressus as Ye.Ya. Kraeva has proposed previously. Zone Marginulinopsis infracompressus of the NPBSR (fig. 4) is an stratigraphic analogue of Priabonian interregional zone Planulina costata of the CCR [9] due to presence characterizing species Clavulinoides szaboi (Hantk.), Cyclammina pseudocancellata Chalil., Marginulinopsis infracompressus (Thalm.), Marginulina behmi Guemb., Robulus limbosus (Reuss), Turkmenicaella kubinyi (Hantk.), Anomalina granosa (Hantk.), Anomalinoides alazanensis (Hantk.), Brotzenella taurica (Sam.), Cibicidoides tachtaensis (Schutzk.), Cib. kugultaensis (Schutzk.), Cib. bionus (Schutzk.), Heterolepa dutemplei (Orb.), H. pygmea (Hantk.), Svratkina perlata (Andr.), Alabamina almaensis (Sam.), Planulina costata (Hantk.), Grammostomum nobilis (Hantk.), Uvigerina jacksonensis Cushm., Bulimina truncana Guemb., etc.

Some more shallow-water BF associations of the beds are described in I.D. Konenkova's works [30,36]. The first association, the fourth, almian, complex in [36], I.D. Konenkova distinguished from Upper Eocene deposits of depressions of the southern part of US. It includes characterizing species of zone Marginulinopsis infracompressus and also shallow-water taxa Triloculina tricarinata (Terq.), Asterigerina falcilocularis Subb., Elphidium subnodosum (Roem.).

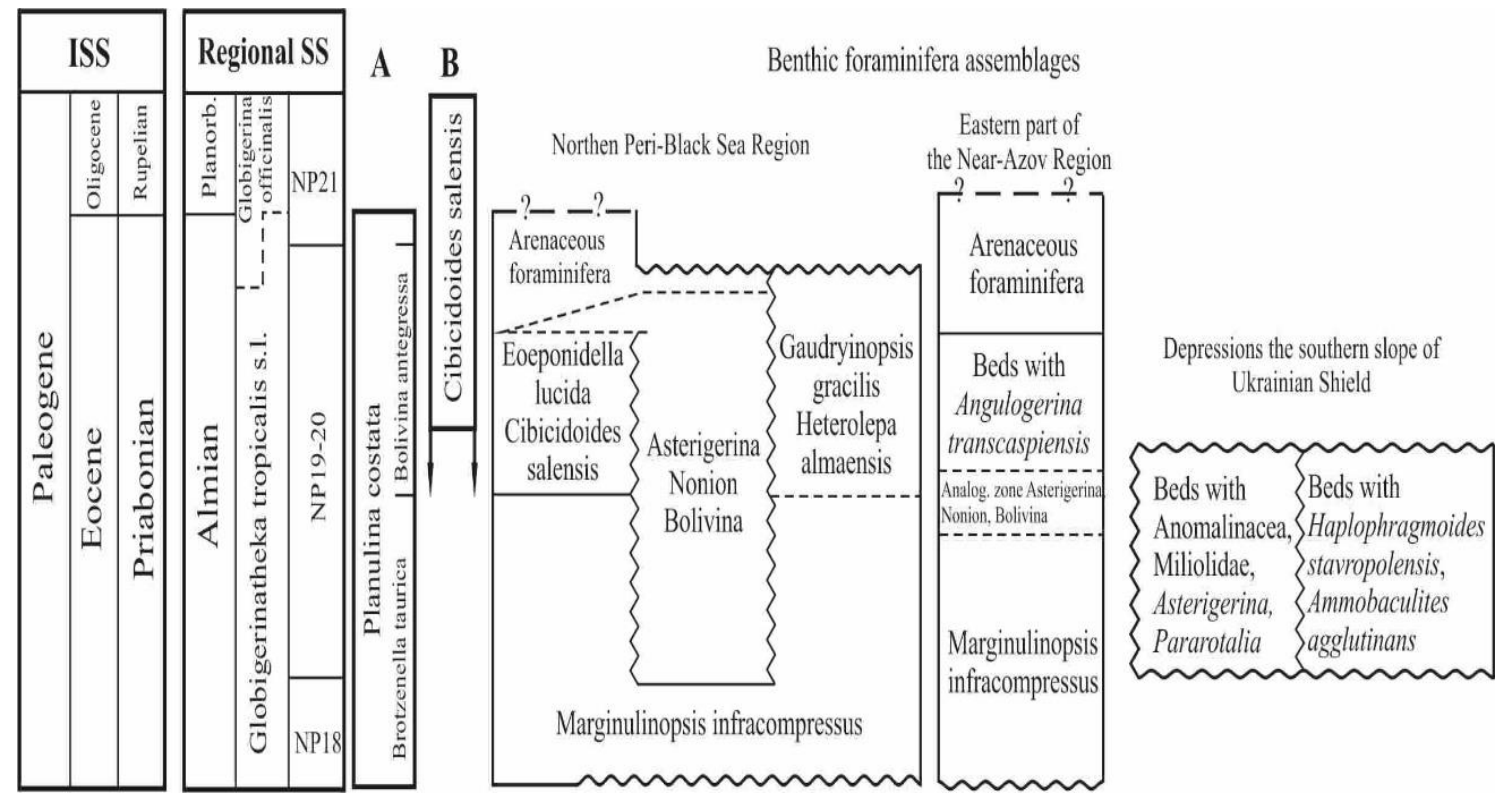

Fig. 4. Sequence and space-time relationships of small benthic foraminifera assemblages in Priabonian of the southern Ukraine

A - interregional benthic foraminifera zones of the Crimea-Caucasus Region [9];

B - regional benthic foraminifera zone of the Sal-Manych-river interflue [9] 
The second assemblage, "zone Bolivina" in [30], I.D. Konenkova identified in borehole drilled in the Malaya Belozerka area (the north of eastern part of the NPBSR). These associations are characterized by various and numerous BF Anomalina granosa (Hantk.), Cibicides tachtaensis (Schutzk.), C. kugultaensis (Schutzk.), C. bionus Schutzk., $C$. jankulaensis (Nutt.), $C$. ungerianus Cushm., Alabamina almaensis (Sam.), Al. perlata (Andr.), Eponides jacksonensis Cushm., Pullenia bulloides Orb., P. quinqueloba Reuss, Baggina iphigenia (Sam.), Oridorsalis praeumbonatus (Mjatl.). Similar BF association from clays and silts of underlying manganese-ore bed of the Nikopol manganese-ore basin was defined by N.G. Savenko [14].

Beds with Asterigerina, Nonionidae, Bolivina, Nummulites. Ye.Ya. Kraeva [41, 43] has described small foraminifera assemblage as "zone Asterigerina and Nonion" from sediments with numerous nummulitids and mollusks of the Odessa-Kherson area section (central part of the NPBSR). She noted that the most abundant and characteristic species for this zone are Eponides stellatus Kraeva, Asterigerina ambiqua Kraeva. After Ye.Ya. Kraeva [43], the zonal association also is distinguished by permanent but not frequent species Cibicides aff. pseudoungerianus Cushm., $C$. aff. oligocenicus Sam., Nonion umbilicatulus Montf., Pullenia quinqueloba Reuss, Eponides perlata (Andr,), Asterigerina bracteata Cushm., Turrilina alsatica Andr., Bolivina reticulata Hantk. In her work [44] Ye.Ya. Kraeva renamed the assemblage as "zone with Asterigerina, Nonion and Nummulites". Later she renamed it as "zone (beds) with Asterigerina, Nonion, Bolivina, Nummulites" [8, 62: p. 7, tabl.].

Similar BF association has been distinguished by A.P. Pechenkina [72] as "the fifth complex" characterizing interlayers of calcareous clays and aleurolites (silts) in the upper part of Paleogene section of the southwestern part of the NPBSR. She identified it as beds with shallow-water assemblage with calcareous foraminifera Rotalia sp., Asterigerina sp. (aff. ambiqua Kraeva), Cibicides janschini J. Nik., C. sulzensis (Herrm.), C. aff. pseudoungerianus Cushm., C. tachtaensis Schutzk., Melonis ex gr. dozulaensis (Chalil.), Nonion aff. granosus (Orb.), Florilus ex gr. boueanus (Orb.), Baggina iphigenia (Sam.), Bolivina ovataeformis Chalil., B. aff. aenariensiformis Mjatl., Baggatella sp., representatives of Lagenidae, Polymorphinidae, single Nummulites ornignyi (Gal.).

Later N.G. Savenko $[82,83,100]$ determined that small BF assemblage of Upper Eocene beds with Nummulites and molluscs of the western part of the NPBSR are characterized by predominance of Asterigerinidae and Nonionidae. Among characteristic species she indicated Cibicidoides sumsarensis N. Byk. ucrainicus Kraeva, Cib. roulensis Kraeva, Melonis dosularensis (Chalil.), Rotalia lithothamnica (Uhlig), Bolivina simplex Balakhm. and Asterigerina stelligera Kraeva.

At the same time I.D. Konenkova [22] published detail biostratigraphic description "beds with Asterigerina, Nonion and Nummulites" of the same region. She noted that BF assemblage of the beds is distinguished by various species of Asterigerinidae, Nonionidae, Discorbidae and Anomalinidae. It includes Asterigerina ambiqua Kraeva, A. crassa-suturata Konen., A. praefrankei Konen., A. jartzevae Konen., A. ambiqua Kraeva forma dorsoplana Konen., Melonis rotulus (Chalil.), Nonion nonionoides (Andr.), Baggina iphigenia (Sam.), Eponides stellatus (Kraeva), Cibicides bionus Schutzk., C. kugultaensis Schutzk., C. ex gr. karpaticus Mjatl., Bolivina microlancetiformis Subb., B. ex gr pusilla Schwag. Small BF associations from the Western Near-Black Sea Region also contain Marginulina behmi (Reuss), Cibicides aff. janschini J. Nik., C. dutemplei (Orb.) praecinatus (Karr.), C. jankulaensis Schutzk., C. kugultaensis Schutzk., C. tahtaensis Schutzk., C. carinatus (Terq.), Elphidium roh/shauseni (Bandy), Bolivina compta Chalil., B. compta carinata Chalil.

As possible analogue of beds with Asterigerina, Nonion and Nummulites in the eastern part of Near-Azov Region, I.D.Konenkova [31] considers layers of noncalcareous silts containing numerous spongue spicules, radiolarians, diatomea and non numerous foraminifera Ammobaculites grossecamerata Ter-Grig., Cylindroclavulina rudislosta (Hantk.), Nodosaria exilis (Neug.), Baggina iphigenia (Sam.), Melonis rotulis (Chalil.), Bolivina nobilis Hantk., B. reticulataformis Chalil., B. praebinaensis Chalil. and rare Asterigerina and Nonion. 
Author's notes. Small BF of descrided beds with Nummulites of the Almian Regiostage should be considered as assemblage-zone Asterigerina, Nonion, Bolivina as Ye.Ya. Kraeva has proposed previously. This zone corresponds to Priabonain large foraminifera beds with Nummulites litoralis, $N$. concinnus, $N$. prestwichianus [112]. Lower part of the nummulits beds is characterized by calcareous nannofossils of zonal interval NP 18-NP 19 [5, 6, 113] characterizing the Almian Regiostage. In Stratigraphic Scheme of Southern Ukraine these nummulits beds are considered to correspond to upper part of the Almian Regional Stage. BF assemblage of zone Asterigerina, Nonion, Bolivina in comparison with that of zone Marginulinopsis infracompressus indicates more shallow-water marine facies of the upper Eocene in the NPBSR (see fig. 4). It should be noted that BF assemblage of zone Asterigerina, Nonion, Bolivina of the western part of the NPBSR includes some characteristic species of zone Priabonian interregional Planulina costata of the CCR [9], namely Marginulina behmi (Reuss), Cibicidoides sulzensis (Herrm.), Cib. tachtaensis (Schutzk.), Cib. bionus (Schutzk.), Turrilina alsatica Andr., Bolivina reticulata (Hantk.), B. compta Chalil., etc.

Beds with Eoeponidella lucida and Cibicidoides salensis. Above marls of "zone Globigerinoides conglobatus" (= zone Globigerinatheka tropicalis; zone Marginulinopsis infracompressus in the article) in the Razdelnaya area section (the southwestern part of the NPBSR), Ye.Ya. Kraeva [41] has described foraminifera assemblage which she has named as "zone with Globigerina bulloides and arenaceous foraminifera". After her the main pecularities of this assemblage are as follows: considerable quantity of arenaceous foraminifera Reophax ex gr. nodulosus Br., R. plana Halk., R. scalaria Grzyb., Proteonina fusiformis Will., Haplophragmoides eggeri Cushm., Clavulina szaboi Hantk., Heterostomella dalmatina Liebus and others; impoverishing of speciments quantity and foraminifera species. As characterizing species of the zone she determined Robulus carinatus Kraeva, Frondicularia budensis (Hantk.), Uvigerina densecostata Kapt. (msc.), Cassidulina globosa Hantk., Bifarina millepunctata (Tutkow.), Lingulina sp.

At that time from the same region A.P. Pechenkina [40, 72] described resembling assemblage as "an analogue of zone Asterigerina lucida and Cibicides salensis" be characterizing by succession of three foraminiferal complexes. The first complex in the main consists of arenaceous foraminifera with dominating Rhabdammina sp., Saccammina grzybowskii Bogd., S. variabilis Bogd., Reophax sp., Ammobaculites sp., Heterostomella sp., Haplophragmoides stavropolensis Ter-Grig forma micra. Among calcareous foraminifera in the complex, Cibicides aff. dutemplei (Orb.), Melonis aff. anulatum (Chalil.) striata Chalil., Baggatella ? sp., Uvigerina ex gr. tenuistriata Nutt. (non Reuss), Bolivina simplex simplex Bal. are present. In general, A.P. Pechenkina characterized deposits with that association as beds with assemblage of mainly primitive agglutinated foraminifera Rhabdammina, Saccammina and others, single calcareous species (Uvigerina), numerous radiolaria, diatoms and spongue spicules.

After A.P. Pechenkina the second complex of "zone Asterigerina lucida and Cibicides salensis" is distinguished by various agglutinated foraminifera and abundant radiolarians, diatoms and spongue spicules. Among foraminifera the most numerous and characteristic are Saccammina variabilis Bogd., Reophax aff. scalaria Grzyb., Ammodiscus granatus Subb. (msc.), Haplophragmoides stavropolensis Ter-Grig., Ammobaculites sp., Trochammina parva Cushm. et Laim., Tr. sp., Trochamminoides sp., Spiroplectammina praecarinata J. Nik. vislovensis J. Nik. Sometimes single calcareous species Melonis ex gr. dozularensis (Chalil.), Cibicides ex gr. borislavensis Ais. are found.

The third complex of "zone with Asterigerina lucida and Cibicides salensis" consists of calcareous foraminifera Rotalia sp., Asterigerina aff. ambiqua Kraeva, As. lucida Minakova, Melonis ex gr. dosularensis (Chalil.), Cibicides janchini J. Nik., C. sulzensis (Hermm.), C. extremus Schutzk., C. aff. macrurus N. Byk., Baggina iphigenia (Sam.), Nonion aff. granosus (Orb.), Bolivina ovataeformis Chalil., B. aff. aenariensiformis Mjatl. and others, accompanying with single Nummulites orbignyi (Gall.). A.P. Pechenkina noted the more shallow-water character of the third complex. 
It is necessary to note that A.P. Pechenkina considered "zone Asterigerina lucida and Cibicides salensis" to be of early Oligocene age and correlated it with the Khadum Horizon of the Northern Fore-Caucasus grounded on stratigraphic views of that period.

The same succession of foraminifera associations was described by Ye.Ya. Kraeva [46] in the Rojlanka borehole section in interval 472,4-351 m. Siltstones and silts $(457-351 \mathrm{~m})$ with mollusks and BF Ye.Ya. Kraeva correlated with the Khadum Horizon of Lower Oligocene. But later it was determined that deposits of the same interval include calcareous nannofossils of upper Eocene Zones NP 19/20 and NP 21 [56, 113].

N.G. Savenko $[83,100]$ considered "zone Asterigerina lucida and Cibicides salensis" Upper Eocene and determined its characteristic association consisting of Haplophragmoides ex gr. rotundidorsatum Hantk., H. eggeri Cushm., H. ex gr. kiewensis Kapt., Spiroplectammina azovensis J. Nik., Marginulina behmi (Reuss), Asterigerina lucida Minak., Cibicides salensis J. Nik. and others. Also she noted connections arenaceous foraminifera with layers of noncalcareous silt rocks.

Author's notes. The described BF assemblage should be considered as assemblage-zone Eoeponidella lucida, Cibicidoides salensis as it was proposed by A.P. Pechenkina. Due to presence Haplophragmoides stavropolensis Ter-Grig., Clavulinoides szaboi (Hantk.), Robulus calcariformis Schwemb., Frondicularia budensis (Hantk.), Cibicidoides sulzensis (Herrm.), Cib. extremus Schutzk., Melonis dozularensis (Chalil.), Eoeponidella lucida (Minak.), Baggina iphigenia (Sam.), Loxostomoides millepunctatus (Tutkow.), Globocassidulina globosa (Hantk.) and others known from Upper Eocene interregional zone Planulina costata of the CCR [9] and its stratigraphic analogue in the other areas [66], the zone Eoeponidella lucida, Cibicidoides salensis of the southwestern part of the NPBSR should be considered to be of Priabonian age (see fig. 4).

Beds with arenaceous foraminifera. O.K. Kaptarenko-Chernousova, E.S. Lipnik [19] described from hole drilled near Chkalov village in the south-western part of the Near-Azov Region the assemblage with arenaceous foraminifera consisting of numerous Rhabdammina cylindrica Glaessn., Psammosphaera fusca Schultze., Proteonina fusiformis Will., Pr. ampulacea Brady, Ammodiscus incertus (Orb.), Reophax scalaria Grzyb., R. plana Halk., Ammobaculites agglutinans (Orb.), Haplophragmoides kiewensis Kapt., H. rotundidorsatum Hantk., H. sp., Cyclammina cancellata Brady, Spiroplectammina carinata (Orb.), Textularia sp., non-numerous and poor preserved calcareous speciments Spiroloculina sp., Gyroidina soldanii Orb., Cibicides lobatulus (Walk. et Jac.), Anomalina sp. They noted that clays including that BF assemblage overlay marls with foraminifera of "the Kiev Stage" and underlay siliceous clays with abundant radiolarians and spongue spicules, clayey aleurolite with numerous Spiroplectammina carinata (Orb.). Based on comprising the assemblage with arenaceous foraminifera with that of "the Kiev Stage" of the Dnieper-Donets Depression, O.K. Kaptarenko-Chernousova and E.S. Lipnik have corresponded the siliceous clays with arenaceous foraminifera of the Near-Azov Region to Lower Oligocene.

Ye.Ya. Kraeva [41, 44] has considered assemblage with arenaceous foraminifera as zone due to it stratigraphic position between beds with Upper Eocene foraminifera and Oligocene "zone with Spiroplectammina carinata". She noted that this assemblage was reported by O.K. Kaptarenko-Chernousova and E.S. Lipnik [19] in the south-western part of the Near-Azov Region and A.P. Pechenkina [40] from borehole drilled near Mirnoe village the Odessa area (the southwestern part of the NPBSR). After Ye.Ya. Kraeva, zonal association consists of representatives of genera Rhabdammina, Proteonina, Ammodiscus, Reophax, Ammobaculites, Haplophragmoides, Cyclammina, Spiroplectammina, Frankeina. Later in her other publication [96] she concluded that assemblage with arenaceous foraminifera characterizes the Rubanovka Beds in the NPBSR.

A.P. Pechenkina, Ye.Ya. Kraeva [59] have examined distribution of arenaceous foraminifers association from the south-western part of the Near-Azov Region to the eastern part of the NPBSR. They have considered the assemblage of arenaceous foraminifera of the NPBSR as an analogue of "zone Haplophragmoides deformabilis" of the Stavropol Region $[59,73]$. Researchers considered "zone of arenaceous foraminifers" as beds with mainly agglutinated foraminifera occur 
between Upper Eocene deposists and that of "zone Spiroplectammina carinata". Zonal association includes Saccammina variabilis Bogd., Saccammina sp., Reophax sp., Ammobaculites sp., Hyperammina sp., Haplophargmoides deformabilis Subb., Trochammina exposited Ter-Grig. (msc.), Ammomarginulina foliaceus (Brady), Textularia sp., Spiroplectammina azovensis J. Nik., Gaudryina gracilis (Cushm. et Laim.), also calcareous species Cibicides ex gr. sulzensis (Hermm.), C. pseudoungerianus Cushm., C. extremus Schut., Melonis dozularensis Chalil., Globulina gibba Orb., Pyrulina cylindroides (Roem.).

From the end of sixties, the zone of arenaceous foraminifera was considered as stratigraphic analogue of "beds with Lenticulina herrmanni" of Lower Oligocene in the NPBSR [31, 42, 52, 56, 88, 93, 111]. Zonal BF complex includes agglutinated species Saccammina variabilis Bogd., Rhabdammina aff. cylindrica Glaessn., Reophax aff. elongata Grzyb., Hyperammina cf. caucasica Bogd., Haplophragmoides stavropolensis Ter-Grig., H. deformabilis Subb., Ammomarginulina foliacea (Brady), Spiroplectammina azovensis J. Nik., Gaudryinopsis gracilis (Cushm. et Laim.) and secreted ones Lenticulina ex gr. herrmanni (Andr.), Cibicidoides extremus (Schutzk.), Cib. oligocenicus (Sam.), Melonis affine (Reuss), M. dozularensis Chalil., Brizalina mississippiensis (Cushm.).

I.D. Konenkova [36] described beds with agglutinated foraminifera, numerous spongue spicules and radiolarians from Upper Eocene shallow-water deposits of depressions the southern part of US. The BF association includes species known from "zone of arenaceous foraminifera" of the Northern Near-Black Sea Region, namely Reophax scalaria Grzyb., R. plana Halk., Ammodiscus incertus Orb., Haplophragmoides stavropolensis Ter-Grig., Ammobaculites agglutinans (Orb.), Trochammina ex gr. florata Ter-Grig. and others.

Author's notes. The described BF assemblage should be regarded as assemblage-zone arenaceous foraminifera as it was proposed by Ye.Ya. Kraeva. Stratigraphic position of zone arenaceous foraminifera today remains still uncertain. In Stratigraphic Schemes of Paleogene deposits of the southern Ukraine [64, 67, 90, 91] the beds with arenaceous foraminifera correspond to the Lower Oligocene and occupy position stratigraphically below zone Spiroplectammina oligocenica. Presence such species as Haplophragmoides deformabilis Subb., H. stavropolensis Ter-Grig., Spiroplectammina azovensis J. Nik., Gaudryinopsis gracilis (Cushm. et Laim.), Cibicidoides extremus (Schutzk.), Cib. oligocenicus (Sam.), Melonis dozularensis (Chalil.), Bolivina mississippiensis (Cushm.) and others identifies the lowest Oligocene regional zones Haplophragmoides fidelis and Haplophragmoides deformabilis of the Stavropol Region (the Central Fore-Ciscaucasus) [9] or zone Cibicidoides salensis of the south-eastern outlying part of Russian Platform and the Skytian Plate after Yu.P. Nikitina [66]. New data on calcareous nannofossils from beds with arenaceous foraminifera of the NPBSR and its analogues in the Crimean Peninsula [3, 56, 94] and other stratigraphical materials [78, 81, 94] show corresponding zone arenaceous foraminifera to Upper Epocene (see fig. 4). But the possibility of trassitional Eocene-Oligocene stratigraphic position of the arenaceous foraminifera assemblage in some sections could not be excluded.

Beds with Gaudryinopsis gracilis and Heterolepa almaensis. I.D. Konenkova [30] from borehole drilled near Malaya Belozerka village (on the north of the eastern part of the NPBSR) described interesting BF assemblage consisting of arenaceous species known from "zone of arenaceous foraminifera" (Ammodiscus tenuiculus Subb., Haplophragmoides deformabilis Subb., H. stavropolensis Ter-Grig., Spiroplectammina vicina (Erem.), Gaudryinopsis grasilis (Cushm. et Laim.), Verneuilina rasilis Subb.) and calcareous ones distributed in upper Eocene - lower Oligocene (Guttulina problema Orb., Anomalina munda (N. Byk.), An. munda assakensis Korov., Heterolepa almaensis (Sam.), Cibicidoides oligocenicus (Sam.), Melonis dozularensis (Chalil.), Baggina iphigenia (Sam.), Caucasina schischkinskyae (Sam.), etc.). She named the assemblage as "zone Gaydryina gracilis and Heterolepa almaensis" and coresponded it to lower Oligocene. This assemblage also includes Reophax scalaria Cz., Saccammina variabilis Bogd., Trochammina florifera Subb., Ammomarginulina foliacea (Brady), Subtilina aff. fidelis (Ter-Grig.), Pyrulina fusiformis (Roem.), Glandulina laevigata (Orb.), Asterigerina perbona 
Konen., A. jucunda Konen., A. jucunda iniqua Konen., Pararotalia canui Bhatia, Bolivina compta carinata Chalil.

Similar BF association in other researchers' publications of previous years were presented as "beds with Heterolepa almaensis" or "analogue of beds with Lenticulina herrmann" [88, 93], as "zone with agglutinated foraminifera" [59] and "beds with mixed complex of foraminifers" and "beds with Trifarina transcaspiensis" [31].

Author's notes. Taxonomic composition of BF of zone Gaudryinopsis gracilis and Heterolepa almaensis is close to zone Cibicidoides salensis of the south-eastern outlying part of the Russian Platform and the Skythian Plate [66]. Yu.P. Nikitina considered zone Cibicidoides salensis to be of early Oligocene age. But according to publication [94] deposits of zone Cibicidoides salensis contain calcareous nannofossils of Zone NP 20 and, thus, should be dated the Priabonian. Thus, based on correlation with zone Cibicidoides salensis, zone Gaudryinopsis gracilis and Heterolepa almaensis of the NPBSR should be compared with the Upper Eocene (see fig. 4).

Beds with Angulogerina transcaspiensis. Ye.Ya. Kraeva [54] has described BF "complex with Trifarina transcaspiensis" from the lower part of mainly non calcareous sands, silts and clays of the south the eastern part of the Near-Azov Region. These deposits she considered as Lower Oligocene. Except index-species Trifarina transcaspiensis (Moroz.) this assemblage includes Hyperammina sp., Saccammina ex gr. ampullacea (Brady), Ammobaculites foliaceus (Brady), Textularia tuaevi (Moroz.), Gavelinella ex gr. munda N. Byk., Caucasina schischkinskyae (Sam.), C. adziderensis Chalil., Caucasina sp., Bolivina mississippiensis Cushm., Seabrookia sp. After Ye.Ya. Kraeva, the beds with Angulogerina transcaspiensis occur below the beds with Lenticulina herrmanni and arenaceous foraminifera in the Lower Oligocene section of that region.

I.D. Konenkova [31] gave more accurate definition the stratigraphic position of the beds with Angulogerina transcaspiensis. After her these beds occur between the layers containing impoverished BF association of upper part of Upper Eocene zone Bolivina antegressa and the beds with mixed BF assemblage (an analogue of zone Eoeponidella lucida and Cibicidoides salensis and zone arenaceous foraminifera in the article). I.D. Konenkova suplemented the species composition of the beds with Angulogerina transcaspiensis with Reophax plana Halk., R. nodulosus (Brady), R. scalaria Grzyb., Saccammina fusiformis (Will.), Rhizammina indivisa Brady, Trochammina advena Cushm., Haplophragmoides stavropolensis Ter-Grig.*, Spiroplectammina vicina Erem., Martinoitella ex gr. communis (Orb.), Frondicularia budensis (Hantk.)*, Alabamina almaensis (Sam.)* Baggina iphigenia (Sam.) ${ }^{*}$, Cibicidoides aff. pseudoungerianus (Cushm.)*, Cib. tahtaensis (Schutzk.)*.

BF of the beds with Ang. transcaspiensis of the eastern part of the Near-Azov Region contain species (marked by $\left(^{\star}\right)$ in the list) known from Upper Eocene zone Marginulinopsis infracompressus, zone Asterigerina, Nonion, Bolivina, zone Eoeponidella lucida and Cibicidoides salensis of the NPBSR. The species Spiroplectammina tuaevi Moroz., Sp. vicina Erem., Brotzenella munda (N. Byk.), Caucasina schischkinskyae (Sam.), Bolivina mississippiensis Cushm. are known from zone Cibicidoides salensis of the Sal-Manych-river interflue [9, 66]. But, because of definition calcareous nannofossils of zone NP 20 [94], deposits of zone Cibicidoides salensis should be consider the Priabonian.

Common BF species of beds with Ang. transcaspiensis of the eastern part of the ACM and zone Gaudryinopsis gracilis and Heterolepa almaensis of the north of eastern part of the NPBSR [30] are Reophax scalaria Grzyb., Ammomarginulina foliacea (Br.), Haplophragmoides stavropolensis Ter-Grig., Baggina iphigenia (Sam.), Brotzenella munda (N. Byk.), Caucasina schischkinskyae (Sam.).

Author's notes. Taxonomic composition of BF the beds with Angulogerina transcaspiensis of the eastern part of the ACM is close to Upper Eocene zone Asterigerina, Nonion, Bolivina, zone Eoeponidella lucida and Cibicidoides salensis, zone Gaudryinopsis gracilis and Heterolepa almaensis of the eastern part of the NPBSR and zone Cibicodoides salensis of the Sal-Manychriver interflue. Thus, on my opinion, the beds with Angulogerina transcaspiensis should be compared with the Priabonian (see fig. 4). 
Beds with Anomalinacea, Miliolidae, Asterigerina, Pararotalia. Due to investigations of I.D. Konenkova [36] and N.G. Savenko, it was determined that "beds with Marginulina infracompressa" in depression the southern part of US are replaced by shallow-water BF association consisting of numerous and various Anomalinacea and Cibicididae, prevalence Rotaliacea, namely Anomalina granosa (Hantk.), An. affinis (Hantk.), An. ex gr. grosserugosa (Hantk.), Heterolepa eocaena (Guemb.), H. pygmeus (Hantk.), Cibicides carinatus (Terq.), C. orbicularis (Terq.), C. lobatulus (Walker et Jac.), Miliolidae, namely Quiqueloculina soljenica Jartz., Q. circularis Born., Q. seminulum (Linne), Q. austriaca(Orb.), Spiroloculina costifera Terq., Triloculina trigonula (Lam.), Nodobaculariella contracta (Terq.), N. jartzevae (Bogd.), frequent Eponides stellatus Kraeva, Discorbis orbicularis Terq., Asterigerina stelligera Kraeva, As. rotula Kaufm., Melonis umbilicatulus (Montf.), Pararoralia lithothamnica orientalis (Cushm. et Berm.), $P$. praecalcar (Mjatl.), Elphidium latidorsatum (Reuss), Cycloloculina annulata Heron-Allen et Earl., Conobrina latdorfiensis Jiess. et Lotsch., Reussella spinulosa (Reuss), Robertina germanica Cushm. et Park., others. According to I.D. Konenkova this BF association is very similar with that of Upper Eocene the Mandrykovka beds of the US. Priabonian age of the beds with Anomalinacea, Miliolidae, Asterigerina, Pararotalia is proved by distinguishing calcareous nannofossils of Priabonian zone NP 19 [36].

Author's notes. Beds with Anomalinacea, Miliolidae, Asterigerina, Pararotalia characterize shallow-water peripheral facies of the southern Ukraine Eocene basin on the southern slope of US in Priabonian time (see fig. 4).

Oligocene. Up to the beginning of the fifties years of XX century in the NPBSR section only two BF assemblages were known as Oligocene. The first, lower, is "horizon with arenaceous foraminifera" now considering late Eocene age (see above). The second, upper, BF association is "horizon with numerous Spiroplectammina carinata". Later Ye.Ya. Kraeva identified "complex with Sphaeroidina" from middle Oligocene deposits of the region.

Today the following biostratigraphic units by BF are distinguished in Oligocene section of the NPBSR and adjacent part of the southern slope of US: zone Spiroplectammina oligocenica (lower Rupelian, the Planorbellian Regiostage); zone Sphaeroidina variabilis (Chattian, the Kerleutian Regiostage, Askania Horizon) and zone Elphidium onerosum, Cibicidoides ornatus (Chattian, the Kerleutian Regiostage, Gornostaevka Horizon).

Planorbellian Regional Stage. Zone Spiroplectammina oligocenica. In literature on Paleogene stratigraphy of the southern part of platformian Ukraine "horizon with Spiroplectammina sp." firstly was reported from upper part of "the Kharkov Stage" in borehole drilled near Stepanovka village (the southwestern part of the Near-Azov Region) in publication [20]. After V.F. Kosireva, the distinguishing species of that horizon are Ammobaculites sp., Haplophragmoides aff. periferoexcavatus Subb. She compared "horizon with Spiroplectammina sp." with middle Oligocene "subhorizon with Spiroplectammina sp." of the Alma section of Crimean Peninsula (after P.B. Samoilova) and with "beds with Spiroplectammina sp." of Paleogene deposits the Nikopol area (after M.V. Yartseva, msc., 1949).

O.K. Kaptarenko-Chernousova and E.S. Lipnik [19] described "horizon with numerous Spiroplectammina carinata (d'Orb.)" in Oligocene section of borehole drilled near Chkalov village (the south of the Molochnaya river basin). Researchers also designated characteristic species for the horizon. There are Cibicides pseudoungerianus Cushm., C. lobatulus (Park et Jon.), Gyroidina soldanii (Orb.), Pullenia sphaeroides (Orb.), Bulimina advena Cushm., Uvigerina asperula Cz., deformed Nonion umbilicatulus (Mont.).

Ye.Ya. Kraeva [41, 42, 44] determined the assemblage with Spiroplectammina as "zone with Spiroplectammina carinata" of the Lower Oligocene in the Tokmak-Melitopol and the Near Sivash areas. As the most representative and abundant species of this zone she marked Spiroplectammina carinata (Orb.), Caucasina schischkinskajae (Sam.), Bolivina mississippiensis Cushm. Less numerous species in the complex are Cibicides oligocenicus (Sam.), C. pseudoungerianus Cushm., Neogyroidina memoranda Subb., Uvigerinella majcopica Kraeva [41, 43, 44, 59, 96]. Among other characteristic species of the assemblage she indicated Ammodiscus incertus (Orb.), Cyclammina cancellata Brady, C. ex gr. constictimargo K. E. Stew., 
Miliolina sp., Globulina gibba Orb., Nonion sp., Pullenia bulloides (Orb.), Gyroidina soldanii (Orb.), Uvigerina ex gr. asperula Cz., Angulogerina ex gr. wilcoxensis (Cushm. et Pont.).

At the same time M.V. Yartseva [107] described BF distribution in manganese-ore bed, underlying and overlying it beds of the Nikopol manganese-ore basin. From silts and clays withing calcareous manganese-ore bed M.V. Yartseva distinguished BF "complex with Caucasina schischkinskyae" regarded by her as an analogue of "horizon with Spiroplectammina" of the Crimea. She indicated [71] Spiroplectammina carinata (Orb.), Sp. ex gr. mayerina Orb., Miliolina ex gr. akneriana Orb., Entosolenia marginata (Walk. et Jac.), Nonion granosum Orb., Asterigerina aff. bracteata Cushm., Gyroidina memoranda Subb., Valvulineria iphigenia Sam., Cibicides praecursorius (Schwag.), C. pseudoungerianus Cushm., C. lobatulus (Walk. et Jac.), Rotalia ex gr. calcar Orb., Caucasina schischkinkyae (Sam.), Angulogerina oligocaenica Andr., Bolivina beyrichi Reuss, B. mississippiensis Cushm., B. microlancetiformis Subb., B. ex gr. elongata Orb., $B$. aff. advena Cushm., Cassidulina laevigata Orb. On my opinion presence Miliolidae, Asterigerina, Rotaliidae, Cibicidoides lobatulus (Walk. et Jac.) indicates more shallow-water conditions of sedimentation in comparison with those in the NPBSR.

From clays of the lower part of over-ore strata in the Bolshoy-Tokmak manganese-ore deposit M.V. Yartseva [86, 87] defined Spiroplectammina carinata (Orb.), Miliolina circularis Born., Cibicides oligocenicus Sam., C. pseudoungerianus Cushm., Gyroidina memoranda Subb., Nonion granosus (Orb.), Pullenia bulloides Orb., Bolivina cf. beyrichi Andr., B. mississippiensis Cushm., Uvigerinella majcopica Kraeva, Angulogerina pulchella Cushm. et Edw., Ang. ex gr. oligocenica Andr., Caucasina schischkinskajae (Sam.), others.

Due to Ye.Ya. Kraeva, I.D. Konenkova, N.G. Savenko, Yu.P. Nikitina, A.P. Pechenkina and M.V. Yartseva's investigations [22, 30-32, 35, 36, 54, 59, 68-71, 73, 87, 88, 99, 107], characteristic features of BF association of zone Spiroplectammina carinata widely dirstributing in Lower Oligocene deposits of the NPBSR, the southern slope of US and adjacent part of the ACM have been diagnosed. Zone Spiroplectammina oligocenica are distinguished in the section by appearance numerous index-species. Zonal BF association is stable and includes [52, 93] Spiroplectammina azovensis J. Nik., Cyclammina cf. constrictimargo (R. E. et K. C. Stew.), Quinqueloculina aff. errmanni Born., Robulus simplicissimus Reuss, Melonis praevis stavropolicus Bogd., M. dozularensis (Chalil.), Pullenia bulloides (Orb.), Neogyroidina memoranda Subb., Pseudoparella caucasica Bogd., Cibicidoides speciosus (Cushm. et Sed.), Cib. expertus (Schutzk. et Ter-Grig.), Cib. pseudoungerianus (Cushm.), Cib. oligocenicus (Sam.), Uvigerinella ex gr. californica Cushm., Baggina iphigenia (Sam.), Caucasina schischkinskayae (Sam.), Bolivina beyrichi Reuss, B. ex gr. mississippiensis Cushm., Uvigerinella majcopica Kraeva, Fursenkoina schreibersiana (Rzeh.), Angulogerina oligocenica Andr., An. gracilis Cushm. et Laim., etc.

Author's notes. Zone Spiroplectammina oligocenica includes characterizing species of lower Rupelian interregional zone Spiroplectammina oligocenica of the Eastern Paratethys [9], namely Spiroplectammina oligocenica J. Nik., Neogyroidina memoranda (Subb.), Uvigerinella majcopica Kraeva, Bolivina mississippiensis Cushm., etc. In the Stratigraphic Scheme of the Southern Ukraine [64] the described BF assemblage is presented as regional zone Spiroplectammina oligocenica marking Upper Planorbellian Regional Substage of Lower Oligocene in the region (fig. 5). In the southern Ukraine the deposits with that BF association correspond to Rupelian calcareous nannofossils Zone NP 22 [3, 36, 56, 68, 69] and dinocyst zones Phthanoperidinium amoenum/Wetzeliella symmetrica and Wetzeliella gochtii [1, 2].

Kerleutian Regional Stage. Zone Sphaeroidina variabilis. Ye.Ya. Kraeva [41, 42] was the first who distinguished in Oligocene section of the Odessa-Kherson area "zone Sphaeroidina" represented by numerous shells Spiroplectammina carinata Orb. follis Kraeva, Nonion umbilicatulus (Montf.), Cibicides aff. pseudoungerianus Cushm., C. oligocenicus Sam., Uvigerinella majcopica Kraeva, Sphaeroidina variabilis Reuss. She also noted that this assemblage's pecularity is presence Miliolina aff. brauni (Reuss), M. cognata (Born.), M. ex gr. circularis (Born.). Ye.Ya. Kraeva also considered "zone Sphaeroidina" to be younger than "zone with Spiroplectammina carinata". 


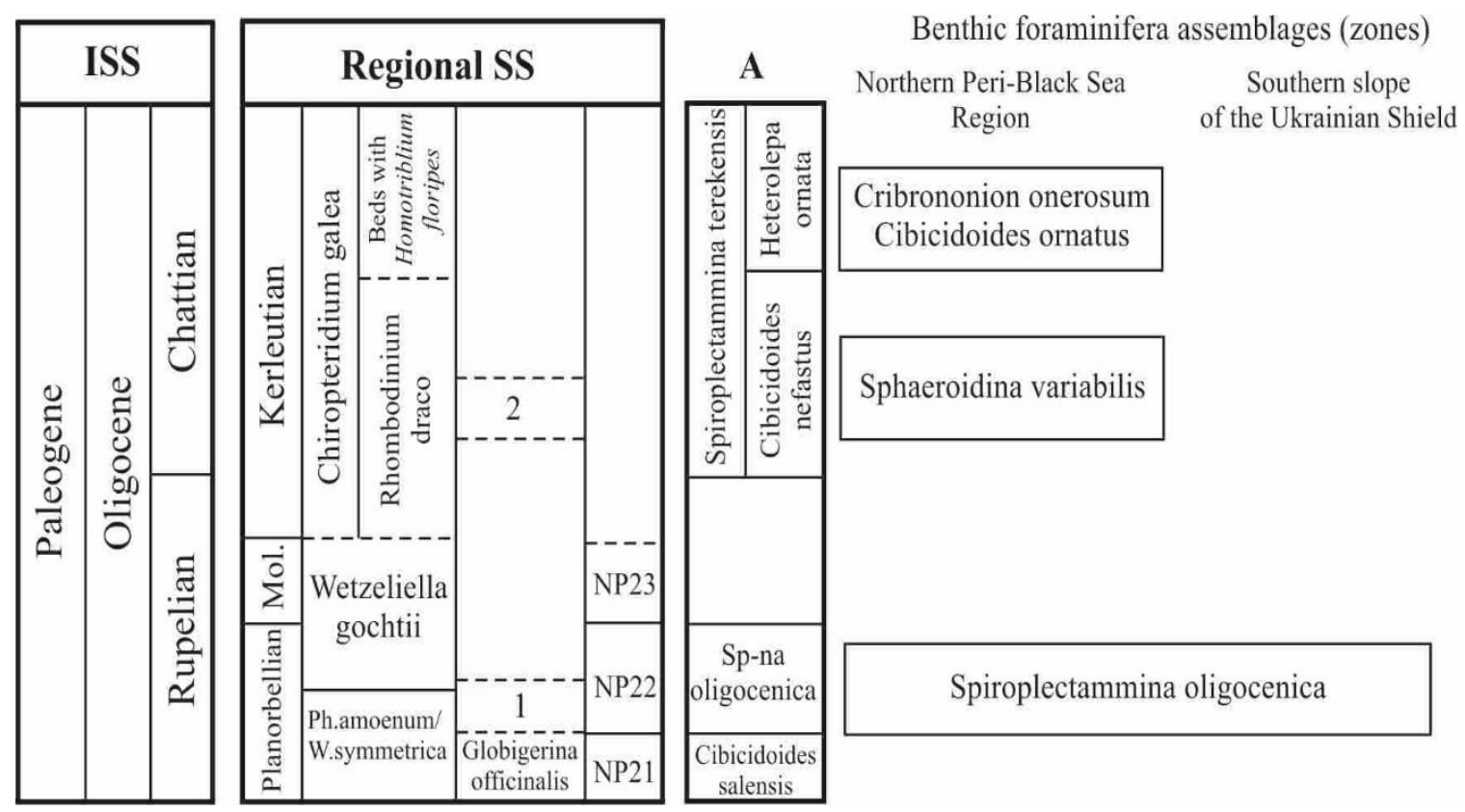

Fig. 5. Sequence of small benthic foraminifera assemblages in Oligocene of the northern Peri-Black Sea Region

A - interregional benthic foraminifera zones of the Eastern Paratethys and regional zones of the Sal-Manych-river interflue [9]; 1 - planktic foraminifera association with Globigerina officinalis, Gl. ciperoensis, Gl. ouachitaensis; 2 planktic foraminifera association with Globigerina senilis, Gl. praebulloides, Gl. ciperoensis

In following years Ye.Ya. Kraeva [43, 44, 46, 61, 98, 99, 111] and N.G. Savenko [70, 84] studied BF taxonomic composition of the zone, their distribution in Oligocene deposits of the NPBSR. Researchers defined that "zone Sphaeroidina variabilis" determines lower part of the Askania Suite of southern Ukraine. N.G. Savenko [70] considered the zone as an age analogue of "beds with Haplophragmoides kjurendagensis" of the upper Kerleut deposits of the Crimean Peninsula.

According to Ye.Ya. Kraeva and N.G. Savenko [51, 95], the common list of foraminifera of "zone Sphaeroidina variabilis" the southern Ukraine includes numerous Haplophragmoides kjurendagensis Moroz., Spiroplectammina terekensis Bogd. (= carinata follis Kraeva), Cibicidoides aff. aknerianus (Orb.) (= nefastus J. Nik.), Cib. majcopicus (J. Nik.), Uvigerinella majcopica Kraeva, Fursenkoina schreibersiana (Cz.), Sphaeroidina variabilis Reuss, nonnumerous Saccammina grzybowskii Bogd., Hyperammina sp., Ammodiscus tenuiculus Subb., Haplophragmoides kjurendagensis kerleuticus Kosir, Haplophragmoides sp., Ammomarginulina foliaceus Brady, Spiroplectammina caucasica Djan., Quinqueloculina errmanni Born., Q. akneriana Orb. var., Saracenaria aff. vaginalis (Reuss), Lenticulina navis (Born.), L. eximia Reuss, Nodosaria calomorpha Reuss, Fissurina laevigata Reuss, Pyrulina fusiformis (Roem.), Guttulina problema Orb., Globulina gibba Orb., Cibicidoides pseudoungerianus (Cush.), Cib. oligocenicus Sam., Cib. stavropolensis (Bogd.), Cib. ornatus (Bogd.), Pullenia bulloides (Orb.), Melonis umbilicatulus (Montf.), M. dozularensis (Chalil.), Nonion granosus (Orb.), Neogyroidina memoranda Subb., Pseudoparella caucasica Bogd., Ammonia proprinqua (Reuss), Cribrononion onerosum (Bogd.), Porosononion dendridicus Bogd., Caucasina schischkinskyae Sam., C. buliminoides Bogd., Uvigerinella californica Cushm., Uv. californica parva Kleinp., Bolivina mississippiensis Cushm., Cassidulina subglobosa Brady, Sphaeroidina austriaca Orb., Robertina declivis Reuss.

Analyzing taxonomic composition of the zone, Ye.Ya. Kraeva [51] concluded genera congeniality (similarity) and a significant number of common species of zones Sphaeroidina 
variabilis and Spiroplectammina oligocenica. Also she denoted non numerous number of species known from Chattian foraminifera assemblages of the Western Europe.

Author's notes. In the NPBSR the zone Sphaeroidina variabilis characterizes the lower part of Askania Suite (Lower Kerleutian Regional Substage) (see fig. 5). Deposits of this zone contain dinocyst association of zone Chiropteridium galea [1,2] and Upper Oligocene planktic foraminifera complex [1, 60, 79]. Due to presence of Spiroplectammina terekensis Bogd., Cibicidoides nefastus (J. Nik.), Pseudoparella caucasica Bogd., Caucasina buliminoides Bogd., Uvigerinella californica Cushm., Sphaeroidina variabilis Reuss and others, zone Sphaeroidina variabilis of the NPBSR corresponds to Chattian zone Spiroplectammina terekensis of the Northern Fore-Caucasus [9] and Upper Oligocene zone Cibicidoides nefastus of the Sal-Manychriver interfluve and Ergeny [66].

Zone Cribrononion onerosum, Cibicidoides ornatus. Ye.Ya. Kraeva [61] has indentified "nonionina complex" in silts and silty clays overlaying beds with Sphaeroidina in borehole 1 drilled near Svobodnyi Port village on the interfluve of the Dnieper and Southern Bug rivers. The assemblage consists of Quinqueloculina aff. selenae (Karrer), Cibicides ornatus Bogd., Nonion dendridicum Chalil., N.granulosum (Orb.), Elphidium onerosum Bogd. Ye.Ya. Kraeva named the found association after dominated BF group and regarded it to be of early Miocene age conditionally.

Due to further investigations of Ye.Ya. Kraeva and N.G. Savenko [51, 52, 84, 93, 98], taxonomic composition of the "nonionida complex" was determined and variability of its associations in different regions of the southern Ukraine was described.

Ye.Ya. Kraeva [91] renamed "nonionida complex" as "Ione Porosononion dendridicus and Elphidium onerosum". She determined this zone as including in the main endemic foraminifera. Also she marked that besides index-species the most characteristic is Cibicidoides ornatus (Bogd.).

Common species list of "nonionida complex" of the southern Ukraine includes Hyperammina sp., Sacammina sp., Quinqueloculina ex gr. ermani Born., Q. ex gr. pseudoseminula Bogd., frequent Q. aff. selenae (Karrer), Q. ex gr. circularis (Born.), numerous Globulina gibba Orb., Glandulina sp., Guttulina sp., numerous Pseudoparella caucasica Bogd., numerous Cibicidoides ornatus (Bogd.), Pullenia sp., Porozononion dendridicus (Chalil.), Nonion granulosum (Orb.), numerous Nonion granosus (Orb.), frequent Melonis dozularensis (Chalil.), Ammonia ex gr. propinqua (Reuss), Cribrononion onerosum (Bogd.), Fursenkoina ex gr. schreibersiana (Cz.), Uvigerinella californica Cushm. [95]. Association consisting of Glandulina, Pseudoparella, Cibicidoides and Nonion, prevalents in the NPBSR. In central part of the Peri-Black Sea Depression the assemblage is supplemented by Quinqueloculina, Fursenkoina, Melonis and Uvigerinella.

Ye.Ya. Kraeva [51] emphasized that in section of the south of former Soviet Union the "nonionida complex" occupies the same stratigraphic position, overlaying the beds with Haplophragmoides kjurendagensis, Sphaeroidina variabilis, Cibicidoides nefastus and underlaying the beds with Neobulimina elongata.

Author's notes. In the NPBSR the zone Cribrononion onerosum and Cibicidoides ornatus characterizes the Gornostaevka Suite which containing late Chattian dinocysts assemblage of beds with Homotriblium floripes of zone Chiropteridium galea [1] (see fig. 5). BF assemblage of zone Cribrononion onerosum and Cibicidoides ornatus of the NPBSR is similar to that of Upper Oligocene zone Cibicidoides ornatus of the Sal-Manych-river interfluve and Ergeny [66] due to common species Pseudoparella caucasica Bogd., Cibicidoides ornatus (Bogd.), Nonion granosus (Orb.), Porozononion dendridicus (Chalil.), Nonion granulosum (Orb.), Melonis dozularensis (Chalil.), Ammonia ex gr. propinqua (Reuss), Cribrononion onerosum (Bogd.), Fursenkoina ex gr. schreibersiana (Cz.), Uvigerinella californica Cushm.

Conclusions. Most of known small BF assemblages of Paleogene deposits of the NPBSR and adjacent parts of the US and ACM had been identified up to beginning the seventies of the last century due to M.V. Jartsteva, V.F. Kosireva, A.M. Voloshina, O.K. Kaptarenko-Chernousova, E.S. Lipnik, A.P. Pechenkina, Ye.Ya. Kraeva, N.G. Savenko and I.D. Konenkova's investigations. 
Up to the end of $X X$ century the researchers had studied taxonomic composition of the BF assemblages, had described their distinctive features and had defined characterizing species, had studied spreading the BF associations in the region.

As it turned out, the BF assemblages of relatively deep-water marine deposits of south the NPBSR include characterizing species of interregional BF zones of the CCR $[9,39]$. But the most of known BF associations relate to the shallow and peripheral facies of the Paleogene sea basin in the south of Ukraine.

As a result, for Paleogene deposits of the NPBSR and adjacent parts of the US and ACM the following sequence and space-time relationships of small BF assemblages could be determined.

Lower Belokamenskian Regional Substage:

- zone Anomalina danica and Cibicidoides commatus (I.D. Konenkova, 1972) [26] considering as stratigraphic analogue of interregional Danian zone Anomalina danica s.l. of the CCR.

Upper Belokamenskian Regional Substage:

- shallow-water beds with Cibicidina bundensis and Nonion multisuturatum

(I.D. Konenkova, 1972) [26].

Kachian Regional Stage:

- zone Anomalina fera and Pulsiphonina prima (A.P. Pechenkina, 1953 [40]; amended I.D. Konenkova, 1968, 1972) [21, 26] and zone Bolivinopsis spectabilis (I.D. Konenkova, 1972) [26] considering as stratigraphic analogues of Thanetian interregional zone Karreriella zolkaensis of the CCR.

Bakhchisaraian Regional Stage:

- BF assemblages corresponding to lower Ypresian interregional zone Pseudogaudryina externa of the CCR.

Simferopolain Regional Stage:

- BF association of upper Ypresian - lower Lutetian superzone Pseudogaudryina pseudonavarroana of the CCR and its shallow-water analogue the zone Vaginulinopsis decorata, Asterigerina stelligera.

Novopavlovkian Regional Stage:

- zone Robulus kuberlinus, Uvigerina bykovae ucrainica (Ye.Ya. Kraeva, 1968) [97] considering as stratigraphic analogue of Lutetian interregional zone Uvigerina costellata of the CCR;

- zone Pararotalia armata, Cibicidoides ex gr. sassei (M.V. Yartseva, 1947 [104]; amended M.V. Yartseva, Ye.Ya. Kraeva, 1983 [108]) and beds with Miliolidae, Epistomaria rimosa (M.V. Yartseva, 1947 [104]; amended M.V.Yartseva, Ye.Ya. Kraeva, 1983 [108]) being shallowwater analogues of zone Robulus kuberlinus, Uvigerina bykovae ucrainica.

Almian Regional Stage:

- zone Marginulinopsis infracompressus (Ye.Ya. Kraeva, 1954) [41] coresponding to Priabonian interregional zone Planulina costata of the CCR;

- zone Asterigerina, Nonion, Bolivina (Ye.Ya. Kraeva, 1954) [41] and zone Eoeponidella lucida, Cibicidoides salensis (Ye.Ya. Kraeva, 1954 [41]; amended A.P. Pechenkina, 1964 [72]) considering as shallow-water stratigraphic analogues of Priabonian interregional zone Planulina costata of the CCR;

- zone Gaudryinopsis gracilis, Heterolepa almaensis (I.D. Konenkova, 1987) [30], zone arenaceous foraminifera (O.K. Kaptarenko-Chernousova, E.S. Lipnik, 1951 [19]; amended Ye.Ya. Kraeva, 1954 [41]) and beds with Angulogerina trancaspiensis (Ye.Ya. Kraeva, 1979) [54] correlating with zone Cibicidoides salensis of the south-eastern part of the Russian Platform and Skythian Plate, and zone Eoeponidella lucida, Cibicidoides salensis of the NPBSR;

- beds with Anomalinacea, Miliolidae, Asterigerina, Pararotalia (I.D. Konenkova, 1996) [36] regarding as shallow-water analogues of zone Marginulinopsis infracompressus of the NPBSR.

Upper Planorbellian Regional Substage: 
- zone Spiroplectammina oligocenica (O.K. Kaptarenko-Chernousova, E.S. Lipnik, 1953 [19]; amended Ye.Ya. Kraeva, 1954 [41]) being stratigraphic equivalent of Rupelian interregional zone Spiroplectammina oligocenica of the Eastern Paratethys.

Upper Kerleutian Regional Substage:

- zone Sphaeroidina variabilis (Ye.Ya. Kraeva, 1954) [41] corresponding to Chattian zone Spiroplectammina terekensis of the Northern Fore-Caucasus and to zone Cibicidoides nefastus of the Sal-Manych-river interflue;

- zone Cribrononion onerosum, Cibicidoides ornatus (Ye.Ya. Kraeva, 1966) [61] similar to Chattian zone Cibicidoides ornatus of the Sal-Manych-river interflue.

\section{REFERENCES}

1. Andreeva-Grigorovich A.S., Gruzman A.D., Konenkova I.D. 1993. Correlation of Oligocene deposits the Ukrainian Carpathians and the Northern Near-Black Sea region based on planktonic microorganisms. Paleontological Rev. No 29, p. 73-78. - in Ukrainian.

2. Andreeva-Grigorovich A.S., Zaporozhets N.I., Shevchenko T.V., Aleksandrova G.A., Vasilyeva O.N., lakovleva A.I., Stotland A.B., Savitskaia N.A. 2011. Atlas dinocysts of Paleogene of the Ukraine and adjacent countries Naukova Dumka Press, Kiev, 224 p. - in Russian.

3. Anistratenko O.Yu., Vernigorova Yu.V., Kovalenko V.A., Lulyeva S.A., Ryabokon T.S. 2012. To stratigraphy of Paleogene-Neogene deposits of the Alma depression the Crimea. Tectonics and stratigraphy. Iss. 39, p. 96-110. - in Russian.

4. Bogajets O.H., Voloshina H.M., Cherniak N.Yu. 1962. New data on Cretaceous deposits of the Berdyansk Spit. Reports Acad. Sci. Ukrainian SSR. No. 2, p. 230-233. - in Ukrainian.

5. Bogdanovich E.M. 1979. Stratigraphy of Danian, Paleocene and Eocene deposits of the Northern Near-Black Sea by nannofossils: author's abstract ... Ph.D. thesis Geol.-Mineral Sciences - Kiev, 27 p. - in Russian.

6. Bogdanovich E.M. 1980. Zonal stratigraphy of Lower Paleogene deposits the Northern Near-Black Sea region by nannofossils. Cenozoic Stratigraphy of the Northern Near-Black Sea Region and the Crimea Dnepropetrovsk, p. 61-69. - in Russian.

7. Bogdanovich E.M., Konenkova I.D., Ivanova T.A., Bondar O.V., Manuk V.V. 2006. Stratigraphic position and paleontological peculiarities of Eocene deposits the Dnepropetrovsk region (Quarry Vizirka). Coll. Sci. works Inst. Geol. Sci. NAS of Ukraine: Problems in paleontology and stratigraphy of Proterozoic and Phanerozoic the Ukraine - Kyiv, p. 188-192. - in Russian.

8. Bondarchuk V.G., (Ed.). 1985. Startigraphic Dictionary of Ukrainian SSR - Naukova Dumka Press, Kiev, 240 p. - in Russian.

9. Bugrova E.M., (sci. ed.). 2005. Guidebook of microfauna. Vol. 8. Cenozoic Foraminifera - VSEGEI Press, St. Peterburg, 324 p. - in Russian.

10. Cherniak N.Yu., Bogajets O.T., Volochina G.M., Khadykin F.T. 1961. To stratigraphy of Cretaceous and Paleogene deposits of northern slope the Near-Black Sea depression. Geological Jour. Vol. 21, iss. 2, p.80-85. - in Ukrainian.

11. Gilkman A.l., Savenko N.G., Shvarts G.A. 1981. Structural selection of the Kuberla and Keresta Horizons in the Near-Black Sea Depression. Rep. Acad. Sci Ukrainian SSR, Ser. B. Geology, chemistry, biology. No. 3, p. 5-9. - in Russian.

12. Gozhyk P.F., (ed.). 2012. Stratigraphic Code of Ukraine. 2-nd ed. - Kyiv, 66 p. - in Ukrainian.

13. Gryaznov V.I. 1978. Paleogene oyster beds of the Nikopol manganese deposit. Cenozoic Stratigraphy of the Northern Black Sea Region and the Crimea - Dnepropenrovks, iss. 2, p. 49-59. - in Russian.

14. Gryaznov V.I., Barg I.M. 1975. About accumulation conditions of the subore-bearing sands of the Nikopol manganese ore basin. Rep. Acad. Sci. Ukrainian SSR. Vol. 220, no 3, p. 666-668. - in Russian.

15. Kamenetskiy A.E., Hurevich B.L. 1959. Facies-lithology characteristic and some physical features of the Paleocene and Eocene deposits the north-eastern Crimea and Near-Sivash. Geological Jour. Vol. 19, iss. 1, p. 68-75. - in Ukrainian.

16. Kaptarenko-Chernousova O.K. 1947. To the Paleogene stratigraphy the Nikopol manganese-ore region. Geological Jour. Vol. 8, iss. 4, p. 20-25. - in Ukrainian.

17. Kaptarenko-Chernousova O.K. 1953. Stratigraphy of Paleogene deposits the Near-Black Sea depression (by foraminifera fauna). Geological Jour. Vol. 13, iss. 3, p. 15-23. - in Ukrainian. 
18. Kaptarenko-Chernousova O.K., Holiak L.M., Zernetsky B.F., Kraeva Ye.Ya., Lipnik E.S. 1963. Atlas of characteristic foraminifera of the Jurassic, Cretaceous and Paleogene of the platform part of Ukraine - Acad. Sci. Ukrainian SSR Press, Kiev, 200 p. - in Russian.

19. Kaptarenko-Chernousova O.K., Lipnik O.S. 1953. About Lower Oligocene horizon with arenaceous foraminifera the Near-Black Sea Depression. Geological Jour. Vol. 13, iss. 1, p. 51-62. - in Ukrainian.

20. Khanin A.A. 1950. Stratigraphy and litology of Cretaceous and Paleogene deposits the Near-Azov region. Geological exploration. No. 1, p. 14-22. - in Russian.

21. Konenkova I.D. 1968. New data on Paleocene deposits the Western Near-Black Sea Region. Paleontological. Rev. No. 5, iss. 1, p. 35-41. - in Russian.

22. Konenkova I.D. 1969 a. To the question of age of deposits zone Asterigerina and Nonion the Western NearBlack Sea Region. Paleontological. Rev. No. 6, iss. 1, p. 85-92. - in Russian.

23. Konenkova I.D. 1969 b. The Lower Paleocene deposits the Western Near-Black Sea Region of Ukraine. Rep. Acad. Sci. Ukrainian SSR. Vol. 188, no. 2, p. 406-407. - in Russian.

24. Konenkova I.D. 1969 c. Features of the foraminifera distribution in the Upper Paleocene deposits the NorthWestern Near-Black Sea region. Geology and ore content the south of Ukraine. Iss. 2, p. 10-14. - in Russian.

25. Konenkova I.D. 1970. Lower Paleocene deposits of the Molochnaya river basin. Geology and ore content the south of Ukraine. Iss. 3, p. 49-51. - in Russian.

26. Konenkova I.D. 1972. Foraminifera biostratigraphy of Danian and Paleocene deposits of the Northern NearBlack Sea region: author's abstract ... Ph.D. thesis Geol.-Mineral. Sciences - Kiev, 23 p. - in Russian.

27. Konenkova I.D. 1973. To a question of Lower Paleogene division the Eastern Near-Black Sea region. Geology and Ore Content the South of Ukraine. Iss. 6, p. 21-24. - in Russian.

28. Konenkova I.D. 1979. Paleobiogeographic zoning of the Danian-Paleocene sea basin of the Northern Black Sea region. Questions micropaleontology. Iss. 22, p. 115-121. - in Russian.

29. Konenkova I.D. 1984. Stratigraphy of Cenozoic deposits the Eastern Near-Azov based on foraminifera. Cenozoic Stratigraphy of the Northern Near-Black Sea region and the Crimea - Dnepropetrovsk, p. 21-30. - in Russian.

30. Konenkova I.D. 1987. Peculiarities of foraminifera distribution in Eocene and Oligocene boundary deposits the Eastern Near-Black Sea region. Paleontological Rev. No 24, p. 95-100. - in Russian.

31. Konenkova I.D. 1998. Peculiarities of foraminifera distribution in Eocene-Oligocene boundary deposits the Eastern Near-Azov Region. Paleontological Rev. No 32, p. 5-14. - in Ukrainian.

32. Konenkova I.D., Chernov M.K., Potapchuk I.S., Nazarenko A.M. 1980. About Oligocene - Miocene deposits the Eastern Near-Azov (Krivaya bar). Cenozoic Stratigraphy of the Northern Near-Black Sea Region and the Crimea - Dnepropetrovsk, p. 38-41. - in Russian.

33. Konenkova I.D., Korallova V.V. 1975. New paleontological data about the Lower Eocene deposits the Eastern Near-Black Sea region. Rep. Acad. Sci. Ukrainian SSR, Ser.B. No. 1, p. 18-20. - in Russian.

34. Konenkova I.D., Korallova V.V. 1984. Paleontological justification of the subdivision and correlation of different facies strata of the Paleogene of the North-Eastern Near-Black Sea Region. Paleontology and stratigraphy of the Phanerozoic of Ukraine - Naukova Dumka Press, Kiev, p. 110-114. - in Russian.

35. Konenkova I.D., Korallova V.V., Solovey I.A. 1976. Stratigraphy of the Meso-Cenozoic deposits the eastern part of the Northern Near-Black Sea region based on foraminifera and miospores data. Cenozoic stratigraphy of the Northern Near-Black Sea region and Crimea - Dneproperovsk, p. 50-61. - in Russian.

36. Konenkova I.D., Manuk V.V., Bogdanovich E.M., Korallova V.V. 1996. New data on distribution Upper Eocene deposits in the Southern Near-Dnieper region. Rep. Nat. Acad. Sci. Ukraine. No. 6, p. 100-103. - in Russian.

37. Konenkova I.D., Sheremeta V.G. 1968. Foraminifera and ostracods from Lower Paleocene deposits the NorthEaster Near-Black Sea region. Paleontolological. Rev. No. 5, iss. 2, p. 63-66. - in Russian.

38. Koren T.N., (ex. ed.). 1991. Phanerozoic zonal stratigraphy of the USSR - Nedra Press, Moscow, 160 p. - in Russian.

39. Koren T.N., (sci. ed.). 2006. Biozonal stratigraphy of Phanerozoic in Russia - VSEGEI Press, St. Petersburg, 255 p. - in Russian.

40. Kortsenshtein V.N., Babay V.S., Pechenkina A.P. 1953. Stratigraphy and lithology of Paleogene deposits the Odessa region. Questions of geology and geochemistry of oil and gas (the European part of USSR). Part 2 Moscow, p. 243-271. (Trans. VNIIGas; iss. 2) - in Russian.

41. Kraeva Ye.Ya. 1954. Foraminifera of Upper Eocene and Oligocene deposits the Near-Black Sea depression: author's abstract ... Ph.D. thesis Geol.-Mineral. Sciences - Kiev, 19 p. - in Russian. 
42. Kraeva Ye.Ya. 1956. New data on Oligocene foraminifera the northern part of Near-Black Sea depression. Rep. Acad. Sci. Ukrainian SSR. No. 5, p. 467-470. - in Ukrainian.

43. Kraeva Ye.Ya. 1960. Foraminifera assemblages of Upper Eocene and Oligocene deposits the Near-Black Sea Depression (Western Part). Paleogene deposits of south the European part the USSR - AN SSSR Press, Moscow, p. 230-244. - in Russian.

44. Kraeva Ye.Ya. 1961. Foraminifera of Upper Eocene and Oligocene deposits the northern part of the Near-Black Sea Depression - Acad. Sci. Ukrainian SSR Press, Kyiv, 95 p. - in Ukrainian.

45. Kraeva Ye.Ya. 1963. Characteristic of foraminifera of Middle Eocene deposits the Northern Near-Black Sea region. Rep. Acad. Sci. Ukrainian SSR. No. 2, p. 245-248. - in Ukrainian.

46. Kraeva Ye.Ya. 1964. Stratigraphical and spatial distribution of foraminiferes in Oligocene deposits the Northern Near-Black Sea Region. The Majkop deposits and their age analogues in the Ukraine and Middle Asia - Naukova Dumka Press, Kiev, p. 74-79. - in Russian.

47. Kraeva Ye.Ya. 1970. Some new representatives of Cibicides from Upper Eocene deposits the Northern NearBlack Sea region. Paleontological Rev. No. 7, iss. 1, p. 20-25. - in Russian.

48. Kraeva Ye.Ya. 1971. About study Nodosariida of Paleogene the Ukraine. Rep. Acad. Sci. Ukrainian SSR, Ser. B. No. 4, p. 299-302. - in Ukrainian.

49. Kraeva Ye.Ya. 1972. Small foraminifera from Middle Eocene nummulitic deposits the Northern Near-Black Sea region. Paleontological Rev. No. 9, iss. 2, p. 15-21. - in Russian.

50. Kraeva Ye. Ya. 1973. Characteristic of the Upper Oligocene in the Southern Ukraine key section. Tectonics and Stratigraphy. Iss. 5, p. 40-50. - in Ukrainian.

51. Kraeva Ye.Ya. 1975 a. Geological age of the Askaniia and Gornostayevka Suites the Northern Near-Black Sea Region. Tectonics and Stratigraphy. Iss. 9, p. 76-84. - in Russian.

52. Kraeva Ye.Ya. 1975 b. Small Paleogene foraminifera of platform Ukraine. Justification the Mezo-Cenozoic stratigraphic units of the Ukraine by microfauna - Naukova Dumka Press, Kiev, 231 p. - in Russian.

53. Kraeva Ye.Ya. 1978. About the Kerestian and Kumian Horizons boundary and about analogues of Kumian Horizon in Ukraine. Tectonics and stratigraphy. Iss. 15, p. 83-90. - in Russian.

54. Kraeva Ye.Ya., Chernov M.K. 1979. Peculiarities of composition of foraminifera assemblages in Paleogene the Eastern Near-Azov Region. Rep. Acad. Sci. Ukrainian SSR. No 10, p. 805-807. - in Ukrainian.

55. Kraeva Ye.Ya., Lipnik O.S. 1964. To stratigraphy of Cretaceous and Paleogene deposits the north-western part of Northern Near-Black Sea depression. Geological Jour. Vol. 24, iss. 5, p. 81-88. - in Ukrainian.

56. Kraeva Ye.Ya., Lulyeva S.A. 1985. Foraminifera and nanoplankton in Eocene and Oligocene boundary layers the Southern Ukraine, their stratigraphic, correlational and facial significance. Tectonics and Stratigraphy. Iss. 26, p. 67-79. - in Russian.

57. Kraeva Ye.Ya., Maslun N.V. 1984. Benthic foraminifera significance for subdivision and correlation Paleogene deposits the Ukraine. Geological Jour. Vol. 44, no. 4, p. 107-112. - in Russian.

58. Kraeva Ye.Ya., Orlova L.G. 1962. New data on spreading of Paleocene deposits in the Western Near-Black Sea region. Proc. Odessa Univ. I.I. Mechnikov. Vol. 152. Geology and geography sci. Iss. 8, p. 98-99. - in Russian.

59. Kraeva Ye.Ya., Pechenkina A.P. 1965. To substantiation the Oligocene age of "zone arenaceous foraminifera". Geological Jour. Vol. 25, iss. 5, p. 113-120. - in Ukrainian.

60. Kraeva Ye.Ya., Yartseva M.V. 1973. Characteristic of Oligocene plankton foraminifers the Northern Near-Black Sea region. Rep. Acad. Sci. Ukrainian SSR, Ser. B. No 8, p. 693-696. - in Ukrainian.

61. Kraeva Ye.Ya., Zelinska V.O., Chekhanska H.M. 1966. About the Oligocene upper limit and its faunal characteristic in the Northern Near-Black Sea Region. Rep. Acad. Sci. Ukrainian SSR. No 3, p. 383-387. - in Ukrainian.

62. Kraeva Ye.Ya., Zernetsky B.F. 1969. Paleontological handbook. Vol.3. Foraminifera of Paleogene the Ukraine Naukova dumka Press, Kiev, 200 p. - in Russian.

63. Makarenko D.Ye., Belokrys L.S. 1985. Middle Eocene deposits of the middle course of the Ingulets River. Paleontological Rev. No. 22, p. 78-84. - in Russian.

64. Makarenko D.Ye., Zernetsky B.F., Zelinskaya V.A., Zosimovich V.Yu., Kraeva Ye.Ya., Gorbunov V.S., Ivanik M.M., Maslun N.V., Stotland A.B., Blank M.Ya. 1987. Stratigraphic scheme (unified) of Paleogene deposits the Ukraine - Naukova Dumka Press, Kiev, 116 p. - in Russian.

65. Nikitina Yu.P. 1963. About the Kiev and Kharkov Stages the Skythian Platform. Bull. Moscow Soc. Naturalists, Geol. Ser. Vol. 38, no 1, p. 94-107. - in Russian. 
66. Nikitina Yu.P. 1972. Biostratigraphy of Paleogene deposits the south-east of Russian Platform and Skythian Plate: author'r abstract .... Dr. thesis Geol.-Mineral. Sciences - Leningrad, 48 p. - in Russian.

67. Nosovskiy M.F. 1970. The Paleogene deposits the Northern Naer-Black Sea Region (the Southern Ukraine). Geology and Ore content of the South of Ukraine. Vol. 3, p. 3-41. - in Russian.

68. Nosovskiy M.F., Konenkova I.D., Bogdanovich Ye.M. 1982. Question on subdivision Oligocene deposits the Northern Near-Black Sea Region. Cenozoic stratigraphy of the Northern Near-Black Sea Region and Crimea Dnepropetrovsk, p. 26-29. - in Russian.

69. Nosovskiy M.F., Konenkova I.D., Bogdanovich Ye.M. 1984. About the Eocene and Oligocene boundary in the south of Ukraine. Cenozoic stratigraphy of the Northern Near-Black Sea and Crimea. - Dnepropetrovsk, p. 8288. - in Russian.

70. Nosovskiy M.F., Savenko N.G. 1963. About stratigraphic position of sphaeroidina zone in the Maikop deposits the Northern Near-Black Sea. Rep. Acad. Sci. Ukrainian SSR. Vol. 148, no. 5, p. 1179-1181. - in Russian.

71. Nosovskiy M.F., Yartseva M.V. 1960. Paleogene deposits of the southern slope of Ukrainian crystalline massif. Paleogene deposits of south of the European part the USSR - Acad. Sci. USSR Press, Moscow, p. 173-186. in Russian.

72. Pechenkina A.P. 1964. About limit of Upper Eocene and Oligocene deposits the Western Near-Black Sea and Northern Stavropol region by data on foraminifera study. The Maikop deposits and their age analogues in the Ukraine and Middle Asia - Naukova Dumka Press, Kiev, p. 80-100. - in Russian.

73. Pechenkina A.P. 1971. Micropaleontology characteristic of lower part the Oligocene of Crimea, Near-Black Sea depression, Western and Central Cis-Caucasus. Cenozoic stratigraphy and paleogeography of gas and oil areas the south USSR - Nedra Press, Moscow, p. 104-116. (Proc. VNIIGas; Iss. 31/39-32/40). - in Russian.

74. Ryabokon T.S. 1992. Distribution and habitat conditions of benthic foraminifera in Eocene deposits of the southern slope the Ukrainian Schield. The geological history of ecological environments on the territory of Ukraine - Naukova Dumka Press, Kiev, p. 98-102. - in Russian.

75. Ryabokon T.S. 1993. Middle Eocene Foraminifera of the southern slope the Ukrainian Schield: author's abstract .... Ph.D. thesis Geol.-Mineral. Sciences - Kyiv, 21 p. - in Ukrainian.

76. Ryabokon T.S. 2006 a. Biostratigraphic significance of Middle Eocene Foraminifera of southern part the US. Coll. Sci. works Inst. Geol. Sci. NAS of Ukraine: Modern directions of Ukrainian geological science. - Kyiv, p. 255276. - in Russian.

77. Ryabokon T.S. 2006 b. Small benthic Foraminifera of Middle Eocene of southern part the Ukrainian Schield. Coll. Sci. works Inst. Geol. Sci. NAS of Ukraine: Problems of paleontology and biostratigraphy of Proterozoic and Phanerozoic the Ukraine - Kyiv, p. 188-192. - in Russian.

78. Ryabokon T.S. 2016 b. The Chkalovo beds (Upper Eocene, Priabobian, Almian Regiostage) of the Western Near-Azov Region. Problems of theoretical and applied mineralogy, geology, metallogeny of mining regions: Materials X-th Intern. sci.-practical conf. Krivyi Rir, p. 42-46. - in Ukrainian.

79. Ryabokon T.S. 2016 a. Directions actualizations of stratigraphic scheme of Oligocene deposits of the Northern Near-Black Sea Region and adjacent part of the US. Coll. Sci. works Inst. Geol. Sci. NAS of Ukraine. Vol. 9, p. 114-149. - in Ukrainian. doi: 10.30836/igs.2522-9753.2016.144739

80. Ryabokon T.S. 2017. Foraminiferal assemblages of the Paleocene of Northern Ukraine. Dnipropetrovsk Univ. Bull. Ser. Geology, Geography. Vol. 25(1), p. 80-92. - in Ukrainian. doi:10.15421/111710

81. Ryabokon T.S. 2017. The Rubanovka beds of the Eastern Near-Black Sea Region. Modern geological science and practice in research of students and young specialists: Materials XIII All-Ukrainian sci.-practical conf. Krivyi Rir, p. 33-38. - in Ukrainian.

82. Savenko N.G. 1968. Stratigraphic characteristic of Upper Eocene deposits of the Inguletz-Southern Bug interfluve (North-Western Near-Black Sea). Rep. Acad. Sci. Ukrainian SSR, Ser.B. No. 1, p. 39-41. - in Ukrainian.

83. Savenko N.G. 1971. Biostratigraphy of Upper Eocene deposits the Near-Black Sea depression by small foraminifera: author's abstract ... Ph.D. thesis Geol.-Mineral Sciences - Kharkov, 18 p. - in Russian.

84. Savenko N.G. 1973. The Paleogene and Neogene boundary layers in the Near-Black Sea Depression. Tectonics and Startigraphy. Iss. 5, p. 52-55. - in Ukrainian.

85. Selin Yu.I. 1960. About Upper-Eocene deposits the Bolshoy Tokmak manganese-ore deposit. Geological Jour. Vol. 20, iss. 3, p. 35-41. - in Ukrainian.

86. Selin Yu.l., 1962. Oligocene deposits of the Bolshoi Tokmak manganese deposit. Bull. Moscow Soc. Naturalists, Geol. Ser. Vol. 37, iss. 1, p. 72-84. - in Russian. 
87. Selin Yu.I. 1964. Stratigraphy and mollusks of Oligocene deposits the Bolshoi Tokmak manganese-ore region Nedra Press, Moscow, 239 p. - in Russian.

88. Shutskaya E.K., (ed.). 1970. A decision of colloquium on micropaleontological justification the limit of Eocene and Oligocene at the territory of the south the USSR - VNIGNI Press, Moscow, 30 p. - in Russian.

89. Shutskaya E.K., 1970. Stratigraphy, foraminifera and paleogeography of Lower Paleogene the Crimea, CisCaucasians and Western Central Asia - Nedra Press, Moscow, 255 p. - in Russian.

90. Stratigraphic scheme of Phanerozoic formations of Ukraine for a new generation of geological maps. Graphic Applications. 1993 - Kiev. - in Russian.

91. Teslenko Yu.V., (ex. ed.). 1984. Geology of the UkrSSR shelf. Stratigraphy (shelf and shore of the Black Sea) Naukova Dumka Press, Kiev, 183 p. - in Russian.

92. Teslenko Yu.V., (ed.). 1997. Stratigraphic Code of Ukraine - Kyiv, 39 p. - in Ukrainian.

93. The biostratigraphic justification of boundaries in Paleogene and Neogene Ukraine, 1979. - Naukova Dumka Press, Kiev, 195 p. - in Russian.

94. Vaga D.-D.O. 2007. The Paleocene-Eocene nannofossils of the southern rim of the East-European Platform: author's abstract ... Ph. D. thesis Geol. Sciences - Kyiv, 28 p. - in Ukrainian.

95. Veselov A.A. 1969. The Paleogene and Neogene boundary in the south of Ukraine. The Neogene stratigraphy of Moldova and south Ukraine - Kishinev, p. 33-55. - in Russian.

96. Veselov A.O., Kraeva Ye.Ya. 1963. Stratigraphy of Oligocene deposits the North-Eastern Near-Black Sea Region. Geological Jour. Vol. 23, iss. 4, p. 39-49. - in Ukrainian.

97. Veselov A.A., Kraeva Ye.Ya. 1968. Stratigraphic analogs of the Kuberla Horizon in the Northern Near-Black Sea region. Geological Jour. Vol. 28, iss. 4, p. 103-108. - in Russian.

98. Veselov A.A., Kraeva Ye.Ya., Shchekina N.A. 1969. To a question on the Paleogene and Neogene boundary in the Near-Black Sea Depression. Rep. Acad. Sci. Ukrainian SSR. Vol. 188, no 4, p. 881-884. - in Russian.

99. Veselov A.A., Kraeva Ye.Ya., Savenko N.G., Sheremeta V.G. 1969. Biostratigraphy of Oligocene sections the Northern Near-Black sea region. Geological Jour. Vol. 28, iss. 1, p. 104-108. - in Russian.

100. Veselov A.A., Kraeva Ye.Ya., Savenko N.G., Sheremeta V.G. 1971. Stratigraphy of Upper Eocene deposits the Northern Near-Black Sea Region. Geological Coll. Lviv Geol. Soc. No. 13, p. 46-52. - in Russian.

101. Veselov A.A., Savenko N.G. 1965. New data on stratigraphy of Upper Eocene deposits the Belozerka iron-ore mining deposit. Natural and human resources of the Left-Bank Ukraine and their use. Vol. 6. Geology and minerals - Nedra Press, Moscow, p. 101-104. - in Russian.

102. Voloshina A.M. 1967a. Eight species of Ataxophragmiidae (Foraminifera) from Upper Cretaceous and Paleogene sediments of Eastern Crimea. Paleontological Rev. No. 4, iss. 1, p. 50-57. - in Russian.

103. Voloshina G.M. 1967b. The Upper Paleocene facies in the eastern part the Plain Crimea. Rep. Acad. Sci. Ukrainian SSR, Ser. B. No. 10, p. 866-867. - in Ukrainian.

104. Yartseva M.V. 1947. About some new foraminifera from Paleogene deposits the Nikopol area. Materials on geology and hydrogeology. Coll. No. 4 for 1946, p. 168-172. - in Russian.

105. Yartseva M.V. 1951. About Upper Eocene Miliolida of the Nikopol area and their habitat. Coll. Sci.Works Inst. Geol. Sci., Ser. stratigraphy, paleontology. Acad. Sci. Ukrainian SSR Press, Kiev, Iss. 6, p. 42-68. - in Russian.

106. Yartseva M.V. 1954. To stratigraphy of Paleogene shallow-water deposits of Ukraine by mummulites. Geol. Coll. Kyiv State Univ. T.G. Shevchenko. No. 5, p. 21-38. - in Russian.

107. Yartseva M.V. 1959. To the stratigraphy of Oligocene deposits of the north-eastern slope of Ukrainian Crystalline Shield. Geological Jour. Vol. 19, iss. 3, p. 25-36. - in Ukrainian.

108. Yartseva M.V., Kraeva E. Ya. 1983. New data of age and stratigraphic analogues of Eocene deposits of southern slope the US. Tectonics and stratigraphy. No. 4, p. 79-87. - in Russian.

109. Zakharchuk S.M., Kraeva Ye.Ya., Menkes M.A. 1978. About analogues of the Kiberla Horizon on the Bolshoy Kuyalnik-Kuchurgan interfluve (North-Western the Near-Black Sea Region). Tectonics and stratigraphy. Iss. 14, p. 93-96. - in Russian.

110. Zakharchuk S.M., Menkes M.A., Kurishko V.A. 1975. About boundary layers of the Eocene and Oligocene in the North-Western Near-Black Sea region. Geology and Geochemistry of Combustible Minerals. Iss. 43, p. 41-46. in Russian.

111. Zelinskaya V.A., Kraeva Ye.Ya. 1969. Stratigraphy of Upper Eocene and Oligocene deposits of the Ukraine. Geological Jour. Vol. 29, iss. 5, p. 63-74. - in Russian.

112. Zernetsky B.F. 2016. Lager foraminifera biostratigraphy of the Paleocene and Eocene of Platform Ukraine. Coll. Sci. works Inst. Geol. Sci. NAS of Ukraine. Vol. 9, p. 97-113. - in Russian. 
113. Zernetsky B.F., Lulyeva S.A., 1990. Eocene zonal biostratigraphy of European part the USSR - Naukova Dumka Press, Kiev, 96 p. - in Russian.

114. Zernetsky B.F., Ryabokon T.S. 1993. Stratigraphic distribution of benthic foraminifers in the Eocene of the middle course Inguletz River. Tectonics and stratigraphy. Iss. 33, p. 90-94. - in Russian.

115. Zernetsky B.F., Ryabokon T.S. 2013. Paleogene regiostages of the Southern Ukraine. Paleontological. Rev. No 45, p. 37-53. - in Ukrainian.

116. Zhamoida A.I., (ex. ed.). 1977. Stratigraphic Code of the USSR - Leningrad, 79 p. - in Russian.

\section{СПИСОК ЛІТЕРАТУРИ}

1. Андреєва-Григорович А.С., Грузман А.Д., Коненкова І.Д. Кореляція олігоценових відкладів Українських Карпат та Північного Причорномор'я за планктонними мікроорганізмами. Палеонтол. зб. 1993. № 29. C. 73-78.

2. Андреева-Григорович А.С., Запорожец Н.И., Шевченко Т.В. и др. Атлас диноцист палеогена Украины, России и сопредельных стран. Киев: Наук. думка, 2011. 224 с.

3. Анистратенко О.Ю., Вернигорова Ю.В., Коваленко В.А. и др. К биостратиграфии палеоген-неогеновых отложений Альминской впадины Крыма. Тектоніка і стратиграфрія. 2012. Вип. 39. С. 96-110.

4. Богаєць О.Г., Волошина Г.М., Черняк Н.Ю. Нові дані про крейдові відклади Бердянської коси. Доп. АН УРCP. 1962. № 2. С. 230-233.

5. Богданович E.M. Стратиграфия датских, палеоценовых и эоценовых отложений Северного Причерноморья по наннопланктону: Автореф. дис. ... канд. геол.-минерал. наук. Киев, 1979. 27 с.

6. Богданович E.M. Зональная стратиграфия нижнепалеогеновых отложений Северного Причерноморья по наннопланктону. Стратиграфия кайнозоя Северного Причерноморья и Крыма. Днепропетровск, 1980. C. 61-69.

7. Богданович Е.М., Коненкова И.Д., Иванова Т.А., Бондарь О.В., Манюк В.В. О стратиграфическом положении и палеонтологических особенностях эоценовых отложений Днепропетровской области (карьер Визирка). Проблеми палеонтології та стратиграфії протерозою і фанерозою України: Зб. наук. nр. ІГН НАН України - К., 2006. С. 188-192.

8. Стратиграфический словарь УССР / под ред. В.Г. Бондарчука. Киев: Наукова думка, 1985. 240 с.

9. Практическое руководство по микрофрауне. Т.8. Фораминиферы кайнозоя / науч. ред. Э.М. Бугрова. Спб.: Изд-во ВСЕГЕИ, 2005. 324 с.

10. Черняк Н.Ю., Богаєць О.Т., Волошина Г.М., Хадикін Ф.Т. До стратиграфії крейдових і палеогенових відкладів північного схилу Причорноморської западини. Геол. журн. 1961. Т. 21, вип. 2. С. 80-85.

11. Гилькман А.И., Савенко Н.Г., Швари Г.А. О структурном обособлении куберлинского и керестинского горизонтов в Причерноморском прогибе. Докл. АН УССР. Сер. Б. Геол., хим., биол. науки. 1981. № 3. С. 59.

12. Стратиграффічний кодекс України. - 2-е вид. / Гол. Ред. П.Ф. Гожик. Киев, 2012. 66 с.

13. Грязнов В.И. Палеогеновые устричники на Никопольском марганцевом месторождении. Стратиграффия кайнозоя Северного Причерноморья и Крыма. Днепропетровск, 1978. Вып. 2. С. 49-59.

14. Грязнов В.И., Барг И.М. Об условиях накопления подрудных песков Никопольского марганцеворудного бассейна. Докл. АН СССР. 1975. Т. 220, № 3. С. 666-668.

15. Каменецький А.Є., Гуревич Б.Л. Фаціально-літологічна характеристика та деякі фрізичні властивості відкладів палеоцену і еоцену північно-східного Криму і Присивашшя. Геол. журн. 1959. Т. 19, вип. 1. С. 6875.

16. Каптаренко-Чорноусова О.К. До стратиграфії палеогену Нікопольського мангановорудного району. Геол. журн. 1947. Т. 8, вип. 4. С. 20-25.

17. Каптаренко-Черноусова О.К. Стратиграфія палеогенових відкладів Причорноморської западини (за фауною форамініфер). Геол. журн. 1953. Т. 13, вип. 3. С. 15-23.

18. Каптаренко-Черноусова О.К., Голяк Л.М., Зернецкий Б.Ф., Краева Е.Я., Липник Е.С. Атлас характерных фораминифер юры, мела и палеогена платформенной части Украины. Киев: изд-во АН УкрССР, 1963. $200 \mathrm{c}$.

19. Каптаренко-Черноусова О.К., Липник О.С. Про нижньоолігоценовий горизонт піщаних форамініфер Причорноморської западини. Геол. журн. 1953. Т. 13, вип. 1. С. 51-62.

20. Ханин А.А. Стратиграфия и литология меловых и палеогеновых отложений Приазовского района. Разведка недр. 1950. № 1. С. 14-22. 
21. Коненкова И.Д. Новые данные о палеоценовых отложениях Западного Причерноморья. Палеонтол. сб. 1968. № 5, вып. 1. С. 35-41.

22. Коненкова И.Д. К вопросу о возрасте отложений зоны Asterigerina и Nonion Западного Причерноморья. Палеонтол. сб. 1969 а. №. 6, вып. 1. С. 85-92.

23. Коненкова И.Д. О нижнепалеоценовых отложениях северо-западного Причерноморья Украины. Докл. АН СССР. 1969 б. Т. 188, № 2. С. 406-407.

24. Коненкова И.Д. Особенности распределения фораминифер в верхнепалеоценовых отложениях Северозападного Причерноморья. Геология и рудоносность юга Украины. 1969 с. Вып. 2. С. 10-14.

25. Коненкова И.Д. Нижнепалеоценовые отложения бассейна р. Молочной. Геология и рудоносность юга Украины. 1970. Вып. 3. С. 49-51.

26. Коненкова И.Д. Биостратиграфия датских и палеоценовых отложений Северного Причерноморья по фораминиферам: Автореф. дис. ... канд. геол.-минерал. наук. Киев, 1972. 23 с.

27. Коненкова И.Д. К вопросу о расчленении нижнепалеогеновых отложений Восточного Причерноморья. Геология и рудоносность юга Украины. 1973. Вып. 6. С. 21-24.

28. Коненкова И.Д. Палеобиогеографическое районирование датско-палеоценового морского бассейна Северного Причерноморья. Вопр. микропалеонтол. 1979. Вып. 22. С. 115-121.

29. Коненкова И.Д. Стратиграфическое расчленение кайнозойских отложений Восточного Приазовья по фораминиферам. Стратиграфия кайнозоя Северного Причерноморья и Крыма. Днепропетровск, 1984. C. 21-30.

30. Коненкова И.Д. Особенности распределения фораминифер в пограничных эоцен-олигоценовых отложениях Восточного Причерноморья. Палеонтол. сб. 1987. № 24. С. 95-100.

31. Коненкова І.Д. Особливості поширення форамініфер у суміжних еоцен-олігоценових відкладах Східного Приазов'я. Палеонтол. зб. 1998. Вип. 32. С.5-14.

32. Коненкова И.Д., Чернов М.К., Потапчук И.С., Назаренко А.М. Об олигоцен-миоценовых отложениях Восточного Приазовья (коса Кривая). Стратиграфия кайнозоя Северного Причерноморья и Крыма. Днепропетровск, 1980. С. 38-41.

33. Коненкова И.Д., Кораллова В.В. О новых палеонтологических данных о нижнеэоценовых отложениях Восточного Причерноморья. Докл. АН УССР. Сер. Б. 1975. № 1. С. 18-20.

34. Коненкова И.Д., Кораллова В.В. Палеонтологическое обоснование расчленения и корреляции разнофациальных толщ палеогена Северо-восточного Причерноморья. Палеонтология $u$ стратиграфоя франерозоя Украины. Киев: Наук. думка, 1984. С. 110-114.

35. Коненкова И.Д., Кораллова В.В., Соловей И.А. Стратиграфическое расчленение мезо-кайнозойских отложений восточной части Северного Причерноморья по данным фораминифер и миоспор. Стратиграфия кайнозоя Северного Причерноморья и Крыма. Днепропетровск, 1976. С. 50-61.

36. Коненкова И.Д., Манюк В.В., Богданович Е.М., Кораллова В.В. Новые данные о распространении верхнеэоценовых отложений в Южном Приднепровье. Доп. НАН України. 1996. № 6. С. 100-103.

37. Коненкова И.Д., Шеремета В.Г. Фораминиферы и остракоды из нижнепалеоценовых отложений СевероВосточного Причерноморья. Палеонтол. сб. 1968. № 5, вып. 2. С. 63-66.

38. Зональная стратиграфия фанерозоя СССР: справочное пособие / отв. ред. Т.Н. Корень. М.: Недра, 1991. $160 \mathrm{c}$.

39. Зональная стратиграфия фанерозоя России / науч. ред. Т.Н. Корень. Спб: Изд-во ВСЕГЕИ, 2006. 256 с.

40. Корценштейн В.Н., Бабай В.С., Печенкина А.П. К стратиграфии и литологии палеогеновых отложений Одесского района. Вопросы геологии и геохимии нефти и газа (европейская часть СССР). Ч. 2. М., 1953. С. 243-271. (Тр. ВНИИГаз; Вып. 2).

41. Краева Е.Я. Фораминиферы верхнеэоценовых и олигоценовых отложений Причерноморской впадины. Авторефр. дисс. .... канд. геол.-мин. наук. Киев, 1954. 19 с.

42. Краєва Є.Я. Нові дані про олігоценові форамініфери північної частини Причорноморської западини. Доп. АН УРСР. 1956. № 5. С. 467-470.

43. Краева Е.Я. Фораминиферовые комплексы верхнеэоценовых и олигоценовых отложений Причерноморской впадины (западная часть). Палеогеновые отложения юга европейской части СССР. М.: Изд-во АН СССР, 1960. С. 230-244.

44. Краєва Є.Я. Форамініфери верхньоеоценових та олігоценових відкладів північного крила Причорноморської западини. К.: Вид-во АН УРСР, 1961. 120 с. 
45. Краєва Є.Я. До характеристики фрорамініфер середньоеоценових відкладів Північного Причорномор'я (Одесько-Херсонська площа). Доп. АН УРСР. 1963. № 2. С. 245-248.

46. Краева Е.Я. Стратиграфичческое и пространственное распределение фораминифер в олигоценовых отложениях Северного Причерноморья. Майкопские отложения и их возрастные аналоги на Украине. Киев: Наук. думка, 1964. С. 74-79.

47. Краева Е.Я. Несколько новых представителей Cibicides из верхнеэоценовых отложений Северного Причерноморья. Палеонтол. сб. 1970. № 7, вып. 1. С. 20-25.

48. Краєва Є.Я. Про вивчення нодозаріїд палеогену України. Доп. АН УРСР. 1971. Сер. Б. № 4. С. 299-302.

49. Краева Е.Я. Мелкие фораминиферы из среднеэоценовых нуммулитовых отложений Северного Причерноморья. Палеонтол. сб. 1972. № 9, вып. 2. С. 15-21.

50. Краєва Є.Я. До характеристики верхнього олігоцену південноукраїнського опорного розрізу. Тектоніка $i$ стратиграфрія. 1973. Вип. 5. С. 40-50.

51. Краева Е.Я. Геологический возраст асканийской и горностаевской свит Северного Причерноморья. Тектоника и стратиграфрия. 1975 а. Вып. 9. С. 76-84.

52. Краева Е.Я. Мелкие палеогеновые фораминиферы платформенной Украины. Обоснование стратиграфических подразделений мезо-кайнозоя Украины по микрофауне. Киев: Наук. думка, 19756. C. 119-157.

53. Краева Е.Я. О границе керестинского и кумского горизонтов и об аналогах кумского горизонта на Украине. Тектоника и стриграфия. 1978. Вып. 15. С. 83-90.

54. Краєва Є.Я., Чернов М.К. Особливості складу комплексів форамініфер у палеогені Східного Приазов'я. Дon. АН УРСР. Сер.Б. 1979. № 10. С. 805-808.

55. Краєва Є.Я., Линник О.С. До стратиграфії крейдових і палеогенових відкладів північно-західної частини Причорноморської западини. Геол. журн. 1964. Т. 24, вип. 5. С. 81-88.

56. Краева Е.Я., Люльева С.А. Фораминиферы и наннопланктон в пограничных слоях эоцена и олигоцена Южной Украины, их стратиграфическое, корреляционное и фациальное значение. Тектоника и стратиграфрия. 1985. Вып. 26. С. 67-73.

57. Краева Е.Я., Маслун Н.В. Значение бентосных фораминифер для расчленения и корреляции палеогеновых отложений Украины. Геол. журн. 1984. Т. 44, № 4. С. 107-112.

58. Краева Е.Я., Орлова Л.Г. Новые данные о распространении палеоценовых отложений в Западном Причерноморье. Тр. Одес. госун-та им. И.И. Мечникова. Т. 152. Геол.-географр. науки. 1962. Вып. 8. C. $98-99$.

59. Краєва Є.Я., Печенкіна А.П. До обгрунтування олігоценового віку "зони піщаних форамінісер" Північного Причорномор'я. Геол. журн. 1965. Т. 25, вип. 5. С. 113-120.

60. Краєва Є.Я., Ярцева М.В. Характеристика планктонних форамініфрер олігоцену Північного Причорномор'я. Дon. АН УРСР. Сер. Б. 1973. № 8. С. 693-696.

61. Краєва Є.Я., Зелінська В.О., Чеханська Г.М. Про верхню межу олігоцену та його фауністичну характеристику в Північному Причорномор'ї. Доп. АН УРСР. 1966. № 3. С. 383-386.

62. Краева Е.Я., Зернецкий Б.Ф. Палеонтологческий справочник. Т. З. Фораминиферы палеогена Украины. Киев: Наукова думка, 1969. 200 с.

63. Макаренко Д.Е., Белокрыс Л.С. Среднеэоценовые отложения среднего течения реки Ингульца. Палеонтол. сб. 1985. № 22. С. 78-84.

64. Стратиграфическая схема палеогеновых отложений Украины (унифицированная) / Отв. ред. Д.Е. Макаренко. Киев: Наук. думка. 1987. 116 с.

65. Никитина Ю.П. О киевском и харьковском ярусах Скифской платформы. Бюл. Моск. о-ва испытателей природы. Отд. геол. 1963. Т. 38, № 1. С. 94-107.

66. Никитина Ю.П. Биостратиграфия палеогеновых отложений юго-востока Русской платформы и Скифской плиты. Автореф. дисс. ... доктора геол.-мин. наук. Ленинград, 1972. 48 с.

67. Носовский М.Ф. Палеогеновые отложения Северного Причерноморья (Южная Украина). Геология и рудоносность юга Украины. 1970. Вып. 3. С. 3-41.

68. Носовский М.Ф., Коненкова И.Д., Богданович Е.М. К вопросу о расчленении олигоценовых отложений Северного Причерноморья. Стратиграфия кайнозоя Северного Причерноморья и Крыма. Днепропетровск, 1982. С. 21-26.

69. Носовский М.Ф., Коненкова И.Д., Богданович Е.М. О границе эоцена и олигоцена на юге Украины. Стратиграфия кайнозоя Северного Причерноморья и Крыма. Днепропетровск, 1984. С. 82-88. 
70. Носовский М.Ф., Савенко Н.Г. О стратиграфическом положении сфероидиновой зоны в майкопских отложениях Причерноморской впадины. Докл. АН СССР. 1963. Т. 148, № 5. С. 1179-1181.

71. Носовский М.Ф., Ярцева М.В. Палеогеновые отложения южного склона Украинского кристаллического массива. Палеогеновые отложения юга европейской части СССР. М.: Изд-во АН СССР, 1960. С. 173186.

72. Печенкина А.П. О границе верхнеэоценовых и олигоценовых отложений Западного Причерноморья и Северного Ставрополья по данным изучения фораминифер. Майкопские отложения и их возрастные аналоги на Украине и в Средней Азии. Киев: Наук. думка, 1964. С. 80-100.

73. Печенкина А.П. Микропалеонтологическая характеристика нижней части олигоцена Крыма, Причерноморской впадины, Западного и Центрального Предкавказья. Стратиграфия и палеогеография кайнозоя газонефтеносных областей юга Советскогго Союза. М.: Недра, 1971. С. 104-116. (Тр. ВНИИГаз; Вып. 31/39-32/40).

74. Рябоконь Т.С. Распределение и условия обитания бентосных фораминифер в эоценовых отложениях южного склона Украинского щита. Геологическая история экологических обстановок на территории Украины. Киев: Наук. думка, 1992. С. 98-102.

75. Рябоконь Т.С. Форамініфери середнього еоцену південного схилу Українського щита. Автореф. дис. ... канд. геол. - мінер. наук. Київ, 1993. 21 с.

76. Рябоконь Т.С. Биостратиграфическое значение фораминифер среднего эоцена южной части Украинского щита. Сучасні напрямки української геологічної науки: 3б. наук. пр. ІГН НАН України. К., 2006 а. С. 255276.

77. Рябоконь Т.С. Мелкие бентосные фораминиферы среднего эоцена южной части Украинского щита. Проблеми палеонтології та біостратиграффії протерозою і франерозою України: Зб. наук. пр. ІГН НАНУ. Київ, 2006 б. С. 188-192.

78. Рябоконь Т.С. Чкалівські верстви (верхній еоцен, приабонський ярус, альмінський регіоярус) Західного Приазов'я. Проблеми теоретичної і прикладної мінералогії, геології, металогенії гірничодобувних регіонів: Матеріали Х міжнар. наук.-практ. конф. Кривий Ріг, 2016 а. С. $42-46$.

79. Рябоконь Т.С. Напрями актуалізації стратиграффічної схеми олігоценових відкладів Північного Причорномор'я та прилеглої частини Українського щита. 3б. наук. пр. ІГН НАН України. 2016 б. Т. 9. C. 114-149. doi: 10.30836/igs.2522-9753.2016.144739

80. Рябоконь Т.С. Комплекси форамініфер палеоцену Північної України. Вісн. Дніпропетровського університету. Сер.: геол., географ. 2017. 25(1). С. 80-92. doi:10.15421/111710

81. Рябоконь Т.С. Про рубанівські верстви Східного Причорномор'я. Сучасна геологічна наука і практика в дослідженнях студентів і молодих фрахівців: Матеріали ХІІІ Всеукр. наук.-практ. конфр. Кривий Ріг, 2017. C. 33-38.

82. Савенко Н.Г. Стратиграфічна характеристика верхньоеоценових відкладів межиріччя Інгулець - Південний Буг (Північно-Західне Причорномор'я) за форамініферами. Доп. АН УРСР. Сер.Б. 1968. № 1. С. 39-41.

83. Савенко Н.Г. Биостратиграфия верхнеэоценовых отложений Причерноморской впадины по мелким фораминиферам: Автореф. дис. ... канд. геол.-минерал. наук. Харьков, 1971. 18 с.

84. Савенко Н.Г. Пограничні горизонти палеогену і неогену в Причорноморській западині. Тектоніка $i$ стратиграсрія. 1973. Вип. 5. С. 52-55.

85. Селін Ю.І. Про верхньоеоценові відклади Великотокмацького родовища марганцьових руд. Геол. журн. 1960. Т. 20, вип. 3. С. 35-41.

86. Селин Ю.И. Олигоценовые отложения Больше-Токмакского марганцевого месторождения. Бюлл. Моск. общ-ва испытат. природы. Отд. геологии. 1962. Т. 37 (1). С. $72-84$.

87. Селин Ю.И. Стратиграфия и моллюски олигоценовых отложений Больше-Токмакского марганцеворудного района. М.: Недра, 1964. 239 с.

88. Решение коллоквиума по микропалеонтологическому обоснованию границы эоцена и олигоцена на территории юга СССР / ред. Е.К.Шуцкая. М.: ВНИГНИ, 1970. 30 с.

89. Шуцкая Е.К. Стратиграфия, фораминиферы и палеогеография нижнего палеогена Крыма, Предкавказья и западной части Средней Азии. М.: Недра, 1970. 255 с.

90. Стратиграфическая схема фанерозойских образований Украины для геологических карт нового поколения: графические приложения. Киев. 1993. Табл.

91. Геология шельфа УССР. Стратиграфия (шельф и побережья Черного моря) / Отв. ред. Ю.В. Тесленко. Киев: Наук. думка. 1984. 183 с. 
92. Стратиграфрічний кодекс України / Гол. Ред. Ю.В. Тесленко. Киев, 1997. 40 с.

93. Биостратиграфическое обоснование границ в палеогене и неогене Украины. Киев: Наук. думка, 1979. $204 \mathrm{c}$.

94. Вага Д.-Д.О. Нанопланктон палеоцен-еоцену південної периферії Східно-Європейської платформи. Авторефр. дис. ... канд геол. наук. Київ, 2007. 28c.

95. Веселов А.А. О границе палеогена и неогена на юге Украины. Стратиграффия неогена Молдавии и юга Украины. Кишинев, 1969. С. 33-56.

96. Веселов А.О., Краєва Є.Я. Стратиграсрія олігоценових відкладів північно-східного Причорномор'я. Геол. журн. 1963. Т. 23, вип. 4. С. 39-50.

97. Веселов А.А., Краева Е.Я. О стратиграфических аналогах куберлинского горизонта в Северном Причерноморье. Геол. журн. 1968. Т. 28, вып. 4. С. 103-108.

98. Веселов А.А., Краева Е.Я., Щекина Н.А. К вопросу о границе палеогена и неогена в Причерноморской впадине. Докл. АН СССР. Геол. 1969. Т. 188, № 4. С. 881-884.

99. Веселов А.А., Краева Е.Я., Савенко Н.Г., Шеремета В.Г. Биостратиграфическая характеристика разрезов олигоценовых отложений Северного Причерноморья. Геол. журн. 1968. Т. 28, вып. 1. С. 104-108.

100. Веселов А.А., Краева Е.Я., Савенко Н.Г., Шеремета В.Г. Стратиграфия верхнеэоценовых отложений Причерноморской впадины. Геол. сб. Львов. геол. о-ва. 1971. № 13. С. 46-52.

101. Веселов А.А., Савенко Н.Г. Новые данные по стратиграфии верхнеэоценовых отложений Белозерского железорудного месторождения. Природные и трудовые ресурсы Левобережной Украины и их использование. Т. 6. Геология и полезные ископаемые. М.: Недра, 1965. С. 101-104.

102. Волошина А.М. Восемь видов атаксофрагмиид (фораминиферы) из верхнемеловых и палеоценовых отложений восточного Крыма. Палеонтол. сб. 1967а. № 4, вып. 1. С. 50-57.

103. Волошина Г.М. Про фації верхнього палеоцену в східній частині Рівнинного Криму та в суміжних районах. Дon. АН УРСР. Сер. Б. 1967 б. № 10. С. 866-867.

104. Яриева М.В. О некоторых новых фораминиферах из палеогеновых отложений Никопольского района. Материалы по геологии и гидрогеологии. 1947. Сб. № 4 за 1946. С. 168-172.

105. Ярцева М.В. О верхнеэоценовых милиолидах Никопольского района и среде их обитания. Тр. Ин-та геол. наук. Сер. стратиграфрии и палеонтологии. Вып.6. Киев: Изд-во АН УкрССР, 1951. С. 42-68.

106. Ярцева М.В. До стратиграфії мілководних осадів палеогену України по фрауні нумулітів. Геол. $з б$. Київського держ. ун-ту ім. Т.Г. Шевченка. 1954. № 5. С. 21-38.

107. Ярцева М.В. До стратиграфії олігоценових відкладів південно-східного схилу Українського кристалічного щита (за фауною фораміфніфер). Геол. журн. 1959. Т. 19, вип. 3. С. 25-36.

108. Ярцева М.В., Краева Е.Я. Новые данные о возрасте и стратиграфических аналогах эоценовых отложений южного склона Украинского щита. Тектоника и стратиграфия. 1983. № 4. С. 79-87.

109. Захарчук С.М., Краева Е.Я., Менкес М.А. Об аналогах куберлинского горизонта междуречья Большой Куяльник - Кучурган (Северо - Западное Причерноморье). Тектоника и стратиграфия. 1978. Вып. 14. C. 93-96.

110. Захарчук С.М., Менкес М.А., Куришко В.А. О пограничных слоях эоцена и олигоцена в Северо-Западном Причерноморье. Геология и геохимия горючих ископаемых. 1975. Вып. 43. С. 41-46.

111. Зелинская В.А., Краева Е.Я. К стратиграфии верхнеэоценовых и олигоценовых отложений Украины. Геол. журн. 1969. Т. 29, вып. 5. С. 63-74.

112. Зернецкий Б.Ф. Биостратиграфия палеоцена - эоцена платформенной Украины по крупным фораминиферам. 3б. наук. пр. ІГН НАН України. 2016. Т. 9. С. 97-113.

113. Зернецкий Б.Ф., Люльева С.А. Зональная биостратиграфия эоцена Европейской части СССР. Киев: Наук. думка, 1990. $96 \mathrm{c}$.

114. Зернецкий Б.Ф, Рябоконь Т.С. О стратиграфическом распространении бентосных фораминифер в эоцене среднего течения р. Ингулец. Тектоника и стратиграфрия. 1993. Вып. 33. С. 90-94.

115. Зернецький Б.Ф., Рябоконь Т.С. Регіояруси палеогену південної України. Палеонтол. зб. 2013. № 45. C. $37-53$

116. Стратиграфрический кодекс СССР / отв. ред. А.И. Жамойда. Ленинград. 1977. 80 с. 


\section{Т.С. Рябоконь \\ БІОСТРАТИГРАФІЯ ПАЛЕОГЕНУ ПІВДЕННОӤ УКРАЇНИ ЗА ДРІБНИМИ БЕНТОСНИМИ ФОРАМІНІФЕРАМИ: ІСТОРИЧНИЙ ОГЛЯД}

У статті наведено історію біостратиграфії палеогенових відкладів Південної України за дрібними бентосними форамініферами. Висвітлено значення праць 3 вивчення форамініфер О.К. Каптаренко-Чорноусової, Г.М. Волошиної, М.В. Ярцевої, Є.Я. Краєвої, А.П. Печенкіної, Н.Г. Савенко та І.Д. Коненкової. Завдяки їхнім дослідженням визначено послідовність і прострово-часові співвідношення палеогенових комплексів форамініфер у регіоні. Наведено порівняння комплексів палеогену Південної України з міжрегіональними зонами за бентосними форамініферами Кримсько-Кавказького регіону. Статтю супроводжено повним бібліографічним списком з біостратиграфії палеогену Північного Причорномор'я, південного схилу Українського щита за бентосними форамінісерами.

На початку 70-х років XX століття дослідники виділили та описали комплекси форамініфер, характерні для підвідділів і регіональних підрозділів палеогену Південної України. Було визначено систематичний склад комплексів бентосних форамініфер, з'ясовано їхнє поширення в палеогеновому розрізі Північного Причорномор'я, південного схилу Українського щита та прилеглої частини Приазов'я. Для окремих комплексів форамініфер було доведено їхнє регіональне значення; інші виявилися важливими для характеристики та датування світ, товщ, пачок і верств місцевих стратиграфічних схем. Асоціації форамініфер стосовно глибоководних відкладів півдня Північного Причорномор'я містять види зональних комплексів міжрегіональних зон за бентосними форамініферами Кримсько-Кавказького регіону. Більшість із виділених комплексів бентосних форамініфер характерні для порівняно мілководних відкладів палеогенового басейну в Північному Причорномор'ї та його периферійних фацій у межах депресій південного схилу Українського щита. Визначені прострового-часові співвідношення комплексів бентосних форамініфер для регіоярусів палеогенового розрізу Південної України.

Ключові слова: бентосні форамініфери, палеоген, біостратиграфія, Південна Україна.

\section{Т.С. Рябоконь \\ БИОСТРАТИГРАФИЯ ПАЛЕОГЕНА ЮЖНОЙ УКРАИНЫ ПО МЕЛКИМ БЕНТОСНЫМ ФОРАМИНИФЕРАМ: ИСТОРИЧЕСКИЙ ОБЗОР}

В статье изложена история биостратиграфии палеогеновых отложений Южной Украины по мелким бентосным фораминиферам. Показано значение работ по изучению фораминифер О.К. Каптаренко-Черноусовой, А.М. Волошиной, М.В. Ярцевой, Е.Я. Краевой, А.П. Печенкиной, Н.Г. Савенко и И.Д. Коненковой. Благодаря их исследованиям установлены последовательность и пространственно-временные соотношения палеогеновых комплексов фораминифер в регионе. Приведено сопоставление комплексов фораминифер палеогена Южной Украины с межрегиональными зонами по бентосным фораминиферам Крымско-Кавказского региона. Статья сопровождена полным библиографическим списком по биостратиграфии палеогена Южной Украины по мелким бентосным фораминиферам.

К началу 70-х годов прошлого столетия, благодаря исследованиям О.К. Каптаренко-Черноусовой, Е.С. Липник, В.Ф. Козыревой, А.М. Волошиной, М.В. Ярцевой, Е.Я. Краевой, А.П. Печенкиной, Ю.П. Никитиной, Н.Г. Савенко и И.Д. Коненковой, были выделены и описаны комплексы мелких бентосных фораминифер, характерные для региональных подразделений палеогена Южной Украины. Были изучены систематический состав ассоциаций бентосных фораминифер, прослежено их распространение в палеогеновом разрезе Северного Причерноморья и южного склона Украинского щита, прилегающей части Приазовья. Для некоторых из выделенных комплексов фораминифер было доказано их региональное значение; другие сообщества фораминифер оказались важными для характеристики и датирования свит, толщ, пачек и слоев местных стратиграфических схем. Ассоциации фораминифер относительно глубоководных палеогеновых отложений юга Северного Причерноморья содержат виды зональных комплексов межрегиональных зон по бентосным фораминиферам Крымско-Кавказского региона. Большинство из установленных комплексов бентосных фораминифер характерны для относительно мелководных осадков палеогенового бассейна в Северном Причерноморье и фаций его периферии в пределах депрессий южного склона Украинского щита. Определены пространственно-временные соотношения комплексов фораминифер для региоярусов палеогена в разрезе 
Южной Украины. Нижний региоподъярус белокаменского региояруса характеризует зона Anomalina danica, Cibicidoides commatus, которая коррелируется с межрегиональной зоной Anomalina danica s. I. КрымскоКавказского региона; верхний региоподъярус - слои с Cibicidina bundensis, Nonion multisuturatum. Качинский региоярус - зона Anomalina fera, Pulsiphonina prima и зона Bolivinopsis spectabilis, которые сопоставляются с межрегиональной зоной Karreriella zolkaensis Крымско-Кавказского региона. Комплексы фораминифер бахчисарайского региояруса в Северной Причерноморье отвечают стратиграфическому уровню межрегиональной зоны Pseudogaudryina externa Крымско-Кавказского региона. Симферопольский региоярус характеризует зона Vaginulinopsis decorata, Asterigerina stelligera, которая коррелируется с надзоной Pseudogaudryina pseudonavarroana Крымско-Кавказского региона. Новопавловский региоярус - зона Robulus kuberlinus, Uvigerina bykovae ucrainica, которая является стратиграфическим аналогом межрегиональной зоны Uvigerina costellata Крымско-Кавказского региона, и зона Pararotalia armata, Cibicidoides ex gr. sassei и слои с Miliolidae, Epistomaria rimosa. Альминский региоярус - зона Marginulinopsis infracompressus, которая соотвествует межрегиональной зоне Planulina costata Крымско-Кавказского региона; зона Asterigerina, Nonion, Bolivina и зона Eoeponidella lucida, Cibicidoides salensis, слои с Anomalinacea, Miliolidae, Asterigerina, Pararotalia. Зона Gaudryinopsis gracilis, Heterolepa almaensis, зона песчаных фораминифер и слои Angulogerina trancaspiensis коррелируются с зоной Cibicidoides salensis юго-западной окраины Русской платформы и Скифской плиты и полагаются стратиграфическими аналогами зоны Eoeponidella lucida, Cibicidoides salensis Северного Причерноморья. Верхний региоподъярус планорбеллового региояруса характеризует региональная зона Spiroplectammina oligocenica. Верхний региоподъярус керлеутского региояруса - зона Sphaeroidina variabilis, которая коррелируется с зоной Spiroplectammina terekensis Северного Предкавказья и зоной Cibicidoides nefastus Сало-Манычского междуречья; зона Cribrononion onerosum, Cibicidoides ornatus, которая сопоставлена зоной Cibicidoides ornatus Сало-Манычского междуречья.

Ключевые слова: бентосные фораминиферы, палеоген, биостратиграфия, Южная Украина.

Інститут геологічних наук НАН України, м. Київ

Тамара Рябоконь

e-mail: tr_ryabokon@ukr.net

Стаття надійшла: 07.05.2019 